\title{
A Foundation Fact Approach to Hearsay
}

\author{
Eleanor Swift
}

TABLE OF CONTENTS

PAGE

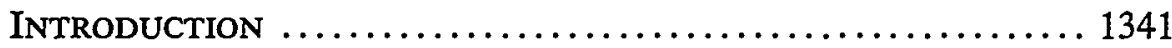

I. The Categorical Approach to the Admission of HEARSAY ................................... 1343

A. The Common Law Development of Categorical Exceptions............................... 1344

B. The Failure of Categorical Generalizations to Insure Accuracy .................................. 1347

II. The Foundation FACT APPROACH IN ThEORY ......... 1354

A. The Basic Standard: The Requirement that the

Proponent Produce a Knowledgeable Process Foundation

Witness ..................................... 1355

B. The Underlying Values...................... 1361

1. Operational Accuracy: Evaluating Hearsay by the Trier's General Knowledge and Experience ........ 1361

2. Increasing the Independence of the Trier of Fact.... 1367

3. Achieving Fairness Through Trial Access to Proof ... 1369

C. Calculating the Costs of the Foundation Fact Approach . 1375

III. The Foundation Fact Approach In Practice........ 1377

A. Unavailability of a Process Foundation Witness ........ 1378

B. The Opponent's Prior Access to the Declarant ......... 1383

C. Statements Made by Multiple Declarants............ 1386

D. Predicting the Future of the Foundation Fact Approach 1389

IV. The Foundation Fact ApPROACH APPlied to THE Current Hearsay Rule ........................... 1390

A. The Definition of Hearsay ...................... 1390

B. Foundation Witnesses Required Under the Current Rule ....................................... 1394

1. Prior Statements Made by a Testifying Declarant/ Witness................................... 1394

2. Business Records ........................... 1398

3. Learned Treatises ........................... 1399

C. Hearsay of a Single Declarant .................. 1400 
1. Present Sense Impressions

2. Medical Statements, Dying Declarations, and Excited Utterances 1403

3. Statements About State of Mind, Against Interest, And About Personal History ................... 1406

4. Ancient Documents........................ 1408

5. Statements by Persons Associated with the Party Opponent ................................ 1409

6. Former Testimony ........................ 1413

D. Hearsay Generated by Multiple Declarants ........... 1415

1. Public Records............................ 1415

2. Public Compilations of Data .................. 1418

3. Reputations ............................... 1419

4. Judgments .............................. 1420

E. The Residual Exceptions ...................... 1423

ConCLUSION ..................................... 1427 


\title{
A Foundation Fact Approach to Hearsay
}

\author{
Eleanor Swift $\uparrow$
}

The traditional hearsay rule purports to produce more accurate trial outcomes by sorting more reliable from less reliable hearsay through the use of categorical exceptions. However, because there is no standard or procedure to verify the accuracy of such outcomes, this claim remains untested. Professor Swift questions the wisdom of this self-justifying system and introduces a new approach to the use of hearsay in trials. Her approach-the foundation fact approach-admits hearsay when the proponent produces foundation facts about the circumstances surrounding a statement that allow the trier of fact to assess the reliability of the statement for itself. The foundation fact approach maximizes the trier of fact's ability to evaluate proof, preserves the trier's independence, and insures fairness between the parties. Professor Swift presents the foundation fact approach as a complete alternative to the hearsay rule, but also suggests how it might be integrated with the existing system of categorical exceptions.

\section{INTRODUCTION}

As a class of evidence, hearsay presents problems for the trier of fact and for the party opponent against whom it is offered. In this Article, I argue that a hearsay rule should explicitly address these concerns, and that the current rule merely glosses over them by purporting to sort more reliable hearsay from less reliable in advance. I have formulated a new approach to the admission of hearsay, called the foundation fact approach, which addresses hearsay problems in functional terms and serves values that legitimate the outcomes of trial adjudication.

The problems raised by hearsay stem from the differences between witnesses and hearsay declarants. In trial adjudication, the trier of fact must make inferences that evaluate the reliability of statements offered as testimonial proof. These inferences depend on foundation facts about the four testimonial qualities of perception, memory, sincerity, and language use of the person who made the statement. Because witnesses are present

$\dagger$ Acting Professor of Law, Boalt Hall School of Law, University of California at Berkeley. I received much more than assistance from my research assistants Sarah Rubenstein, Liz Zeck, Carolyn Bell, Jennifer Glazer, Barbara Flagg, Astrid Giovanetti, and Ragnhild Fougner. Each made a unique contribution. I am very grateful to my secretary, Connie Curtin, for her devotion to this Article through so many drafts. And Bob Cole, who always believed in this project, deserves a handsome reward. 
at trial and subject to questioning, foundation facts about the circumstances affecting their testimonial qualities are readily available. But because a hearsay declarant need not be present at trial, the trier of fact may be deprived of the foundation facts it needs to function. At the same time, the party opponent is deprived of the opportunity to cross-examine hearsay declarants about foundation facts crucial to their statements.

Because of these problems, the current hearsay rule began as a general principle of excluding hearsay from trials. But today the exceptions to this principle admit all hearsay that falls within broad categories believed by judges and legislators to be reliable and necessary. The theory of the categorical exceptions is that admitting reliable hearsay compensates for the problems it causes. In any particular case, the opponent's inability to cross-examine the hearsay declarant causes less concern if the hearsay is believed to be reliable. In the longer run of cases, the problems are presumably outweighed if admitting reliable hearsay increases the overall accuracy of trial factfinding.

However, there is no tested empirical basis for this theory. Current complacency with the categorical approach is based on the self-justifying nature of the hearsay system. Rule drafters-primarily judges, lawyers, and legislators-make assumptions about hearsay categories that seem intrinsically reliable and likely to produce reliable outcomes. They then believe that the categories are valid because the outcomes are accurate. But there is no standard or procedure for testing these assumptions, and the means for verifying accurate outcomes are lacking. The categorical approach is a closed system that cannot spontaneously expose its own shortcomings.

There is an alternative to the theory that reliability compensates for the problems of hearsay. Instead of attempting to sort more reliable from less reliable hearsay in advance, hearsay policy should address the problems raised by hearsay in functional terms. The foundation fact approach obligates the proponent of hearsay to produce a foundation witness knowledgeable about the circumstances affecting the declarant's process of perceiving, remembering, and making a statement about a relevant event. This witness serves as the source of information for the trier's evaluation and is subject to cross-examination by the opponent.

This foundation fact approach to hearsay, defined by the functions of the trial participants, serves three values linked to these functions. These values-operational accuracy, independence of the trier of fact, and fairness between the parties-should govern the choice of our evidence rules. Operational accuracy is achieved by maximizing the trier's ability to evaluate proof. This is a coherent value to aim for in trial adjudication, where objectively accurate results, the aim of the current rule, cannot be verified. Independence of the trier of fact is achieved by 
allowing the trier to determine reliability of evidence for itself, using its own general knowledge and experience. Independence promotes individualized, nonprecedential decisions, and exerts popular control on government, particularly when the trier is a lay jury. Fairness between the parties is achieved by balancing the proponent's freedom to use the widest range of relevant evidence and the opponent's right to have access to the proponent's proof sources at trial. Fairness reflects normative standards for how the adversary system should function, independent of any instrumental effect on the accuracy of outcomes.

In this Article, I present the theoretical and practical aspects of the foundation fact approach to hearsay. Part I examines the current categorical approach and concludes that its claims to accuracy are unsupported. Part II describes the foundation fact approach and compares it to the current categorical rule in terms of the values of operational accuracy, independence of the trier of fact, and fairness between the parties. The basic standard of admission is applied to a series of concrete examples to show how it would work in practice. In Part III, I extend the approach to circumstances where a foundation witness is unavailable, where the opponent had prior access to the declarant, or where there are multiple declarants.

Finally, in Part IV, I analyze how the foundation fact approach could reshape the admission of hearsay within the framework of the current categorical rule. This analysis should mollify concerns that the foundation fact approach is too radical, or that it should not replace the current rule outright. A few categorical exceptions already impose an obligation on proponents similar to the foundation fact approach. Indeed, soine hearsay commentary has become sensitive to the trier's need for foundation facts. However, most exceptions would require revision, and specific suggestions for such revisions are made here. Thus, the foundation fact approach can have a practical impact on the current hearsay rule, making it more coherent, realistic, and reflective of the values of operational accuracy, independence, and fairness. ${ }^{1}$

\section{I}

The Categorical Approach to the Admission OF HEARSAY

This Part first explores the history of the categorical approach to

1. Use of foundation facts is essential to any rational decisionmaker's evaluation of hearsay, but a full-blown foundation fact approach may not be appropriate in administrative, arbitrated, and negotiated decisionmaking. Unlike these alternative methods of dispute resolution, the legitimacy of trial adjudication rests more heavily on values of operational accuracy, independence of the trier, and adversarial fairness. 
hearsay, and then demonstrates how the categorical exceptions do not insure the value of operational accuracy.

\section{A. The Development of Categorical Exceptions}

Enghish judges began to treat hearsay evidence as a problem during the 17 th century. ${ }^{2}$ The outright exclusion of hearsay had its origins in the emerging requirements of a formal trial process. First, the requirement that witnesses testify in open court helped to establish the institutional role of the jury. ${ }^{3}$ Witnesses were to testify only about their knowledge of events and occurrences they had actually perceived; the jury was to evaluate this testimony and form its own independent beliefs and conclusions. Second, witnesses were to testify under oath and subject to immediate cross-exammation. These formal requirements distinguished their testimony from the out-of-court statements of hearsay declarants. Judges then relied on the lack of oath and immediate crossexamination to justify excludimg declarants' statements.

The idea that hearsay threatened the accuracy of jury factfinding emerged in later scholarly and judicial opinion. First, hearsay was thought to be objectively less reliable than witnesses' testimony. ${ }^{4}$ Second, because the hearsay declarant was not cross-examined, the jury lacked mformation necessary for an accurate evaluation. ${ }^{5}$ Additionally,

2. Prior to establishing the general principle of exclusion, courts focused on the purported unreliability of oral hearsay. Throughout the 17 th century, judges commented directly to the jury about the low or uncertain value of such hearsay statements. Later courts tried to require corroboration prior to submitting a case to the jury. By the early 1700 's, these attempts to guide the jury's evaluation of hearsay gave way to the more rigid principle of excluding hearsay from the jury's consideration altogether. See E. Cleary, MCCORMICK ON Evidence § 244, at 724-26 (3d ed. 1984) [hereinafter MCCORMICK]; 5 J. WIGMORE, EvideNCE § 1364 (Chadbourn rev. ed. 1974).

3. J. Thayer, A Preliminary Treatise on Evidence at the Common Law 137-82 (reprint 1969); Wigmore, History of the Hearsay Rule, 17 HARv. L. REv. 437 (1904). See generally B. Shapiro, Probability ANd Certainty in SeVENTEenth-Century ENGLAND 176-92 (1983).

4. See, e.g., Ellicott v. Pearl, 35 U.S. (19 Pet.) 412 (1836); Mima Queen v. Hepburn, 11 U.S. (7 Cranch) 290, 296 (1813) ("Its intrinsic weakness, its incompetency to satisfy the mind of the existence of the fact ... combine to support the rnle that hearsay evidence is totally inadmissible."); G. GILBERT, EVIDENCE 152 (London 1726).

More recent commentary also adopts this view. See, e.g., MODEL CODE OF EvIDENCE introductory note to $\mathrm{ch}$. VI at 217 (1942) ("That a reported statement of a person who has perceived an event is ordinarily of less value than his testimony concerning it, given under oath and subject to cross-examination, no one will deny."); Morgan, Hearsay Dangers and the Application of the Hearsay Concept, 62 HARv. L. REv. 177, 181-83 (1948); Strahorn, A Reconsideration of the Hearsay Rule and Admissions, 85 U. PA. L. REV. 484, 484-85 (1937) (the oath and the test of cross-examination exert pressure for truthfulness).

Park acknowledges the predominance of conventional distrust of hearsay as grounds for its exclusion, but he advances a number of additional reasons for the exclusionary principle. Park, The Hearsay Rule and the Stability of Verdicts: A Response to Professor Nesson, 70 MINN. L. REV. 1057, 1057-62 (1986).

5. See, e.g., C. MCCORMICR, HANdBook of THE LAw of Evidence 457-59 (1954); 5 J. WigMORE, supra note $2, \S 1362$, at 3; see also Morgan, supra note 4, at 188 (stressing the value of 
due to their untrained minds, jurors were thought likely to give undue weight to untrustworthy hearsay. ${ }^{6}$ Exclusion of hearsay protected the jury against this risk.

As Professor Morgan pointed out, however, exclusion actually protects the interests of the party, not the jury, against the risk of inaccurate evaluation. ${ }^{7}$ Cross-examination of witnesses at trial allows the opponent to test the accuracy of the sources of knowledge offered against her. Criminal defendants' emerging rights to confrontation and cross-examination-which required the prosecutor to produce accusing witnesses in court rather than rely on hearsay statements-were important historical constraints on the abusive and even corrupt accusatorial power of the state. $^{8}$

From the very beginning, however, the exclusion of hearsay was never absolute. Certain kinds of hearsay statements (dying declarations or records made im the ordinary course of busmess, for example) were admitted consistently, despite the seemingly absolutist tone of the exclusionary rule. ${ }^{9}$ Throughout the 17th, 18th, and 19th centuries, judges admitted more hearsay by creating additional exceptions to the principle of exclusion.

Despite increasing pressure from lawyers and scholars to liberalize admission, judicial response remained conservative. ${ }^{10}$ In the 20th cen-

cross-examination in uncovering errors in the declarant's four testimonial qualities-language use, sincerity, perception, and memory).

6. The hearsay rule has been attributed to judicial concern about the accuracy of trial outcomes when using a lay jury as the factfinder. The authors of the Model Code of Evidence asserted that distrust of the jury's evaluation emerged during the 19th century. MODEL CODE OF EVIDENCE, supra note 4, at 221; see also Lord Mansfield's opinion in the Berkeley Peerage Case, 171 Eng. Rep. 128, 135 (1811) ("[W]here the jury are the sole judges of the fact, hearsay evidence is properly excluded, because no man can tell what effect it may have upon their minds.") (footnote omitted).

This form of paternalism toward the jury imbued a wide range of common law restrictions on evidence, and it still underlies the current categorical approach to admitting hearsay. See Weinstein, Probative Force of Hearsay, 46 IowA L. REv. 331, 335 (1961).

7. Morgan, supra note 4, at 183-85 (attributing the hearsay rule to concerns about accuracy and faimess unrelated to the institution of the jury and stressing that in its modern form, the rule protects the adversary's option to insist on cross-examination).

8. Charges of corruption were frequently levelled against the prosecutions for treason which marked the 16th and 17th centuries in England. Statutes imposed the requirement of two lawful accusers. This requirement was circumvented by "the strange conceit that one may be an accuser by hearsay," that is, without firsthand knowledge. E. COKE, THIRD INSTITUTES 25 (1641); see also Booker \& Morton, The Hearsay Rule, The St. George Plays and The Road to the Year Twenty-Fifiy, 44 Notre Dame L. ReV. 7, 33-37 (1968).

9. MODEl CODE OF EvidENCE, supra note 4, at 221; 5 J. WIGMORE, supra note 2, $\$$ 14251426.

10. C. MCCORMICK, supra note 5, at 459 ("[T]he failure of the courts to adjust the rules of admissibility more flexibly and realistically to these variations in the reliability of hearsay ... constitutes one of the pressing needs for liberalization of evidence law."); see also R. BAKER, THE Hearsay RULE 168 (1950); 5 J. Wigmore, supra note 2, § 1427. 
tury, significant reform of hearsay exceptions has been effected principally through proposals for legislation, dating from the business records proposals in the study commissioned by the Commonwealth Fund in $1927,{ }^{11}$ and finally concluding with the Federal Rules of Evidence enacted in 1975. ${ }^{12}$ Major reforms proposed in the intervening years consisted of the American Law Institute's Model Code of Evidence published in $1942,{ }^{13}$ the 1953 Uniform Rules of Evidence, ${ }^{14}$ and the California Evidence Code enacted in 1965. ${ }^{15}$

The salient feature of these 300 years is the continued vitality of the categorical approach to admitting hearsay. ${ }^{16}$ Judges, and now legislatures, have categorized the particular kinds of declarants, circumstances, and contents of speech that they believe increase the reliability of hearsay statements. ${ }^{17}$ Although no single theory can account for all of the existing categorical exceptions, commentators agree that a desire to sort the more reliable hearsay from the less reliable has been the predominant justification for the majority. ${ }^{18}$

Many significant evidence scholars, including Professors Morgan, Weinstein, and Wigmore have advocated abandoning the categorical approach to admission. ${ }^{19}$ But none of their proposals for wholesale reform survived in what is today the dominant force in evidence law, the

11. E. Morgan, The Law of Evidence: Some Proposals for Its Reform 51-63 (1927).

12. Act of Jan. 2, 1975, Pub. L. No. 93-595, 88 Stat. 1926 (1975). The history of the Federal Rules is discussed in $1 \mathrm{~J}$. WEINSTEIN \& M. BERGER, WEINSTEIN'S EVIDENCE vii-xi (1986 ed.) and 21 C. Wright \& K. Graham, Federal Practice and Procedure $§ 5006$ (1977).

13. MODEL CODE OF EvIDENCE (1942). The Model Code generated substantial criticism and no jurisdiction enacted it. MCCoRMICK, supra note $2, \S 326$, at 915 .

14. UNIF. R. Evid. (1953). The Uniform Rules were adopted in whole or in part in California, Kansas, New Jersey, and Utah. In 1974, the National Conference of Commissioners on Uniform State Laws adopted a new version of the Uniform Rules based on the Federal Rules of Evidence (as passed by the House of Representatives).

15. CAL. Evid. Code (West 1966).

16. The categorical approach is perhaps the inevitable result of common law development, "in which the Courts looked rather to the discovery of previous cases which covered the point than to any principle on which all the exceptions were, or could be based." R. BAKER, supra note 10, at 165 .

17. Wigmore's rationalization of the categorical exceptions contributed greatly to acceptance of the reliability theory underlying the categorical approach. $5 \mathrm{~J}$. WIGMORE, supra note $2, \S 1420$ (identifying the categorical circumstances with which judges justified dispensing with crossexamination).

18. Today, using categorical trustworthiness to justify admission of hearsay "permeates the major treatises" and is "pervasive in the contemporary debate over hearsay issues." Note, The Theoretical Foundation of the Hearsay Rules, 93 HARV. L. REv. 1786, 1795 (1980); see, e.g., R. BAKER, supra note 10, at 27; MCCORMICK, supra note 2, § 326, at 753; Park, supra note 4, at 1057 58 \& n.3.

19. See, e.g., Model CODE OF Evidence Rule 503 (1942) (representing Morgan's view, as Reporter to the Model Code of Evidence, in favor of admitting all hearsay statements made by testifying witnesses or by unavailable declarants); 5 J. WigMORE, supra note $2, \S 1427$, at 257,264 (proposing a general exception to admit the statements of deceased persons and general trial court discretion to waive the hearsay rule if its strict enforcement would "needlessly interrupt the narrative and if the hearsay incidentally testified to would not be likely to mislead the jury" (emphasis 
final version of the Federal Rules of Evidence. ${ }^{20}$ Current hearsay policy under the Federal Rules remains primarily categorical. To be admitted, hearsay must either fit within a categorically defined exception or exemption, or else survive scrutiny for trustworthiness under the residual exceptions. ${ }^{21}$ And if hearsay statements do fit any such category, judges must admit them except when exercising their discretion in applying three exceptions-business records, public records, and exculpatory statements against interest in criminal cases. The context in which a specific statement was made and the identity of the specific declarant are otherwise immaterial to admission. ${ }^{22}$

\section{B. The Failure of Categorical Generalizations to Insure Accuracy}

A central justification of the categorical approach, exemplified by

omitted)); Weinstein, supra note 6, at 355 (proposing that hearsay be evaluated and admitted on an item-by-item basis under a discretionary rule).

20. The Preliminary Draft of the Federal Rules, submitted for consideration and comment to the bench and bar by the Standing Committee on Rules of Practice and Procedure of the Judicial Conference of the United States on March 31, 1969, proposed abolishing the strict categorical approach. See 46 F.R.D 161, 345-87 (1969) (containing Proposed Rules 8-03, 8-04, and advisory committee's notes). The proposed discretionary approach did not survive the comment process and was withdrawn in favor of the traditional categorical approach. 56 F.R.D. 183 (1972).

Park attributes this rejection to "fear of unbridled [judicial] discretion." Park, supra note 4, at $1060 \mathrm{n} .11$; see also MCCORMICK, supra note 2, $\S 326$, at 916 (legal profession feared loss of predictability). However, residual exceptions were added to the final version of the Federal Rules, reflecting Weinstein's concern for the future growth of the law of hearsay. See FED. R. Evid. 803(24) and 804(b)(5) (described infra at note 22). For a detailed historical discussion of the Preliminary Draft and the genesis of the residual exceptions, see Yasser, Strangulating Hearsay: The Residual Exceptions to the Hearsay Rule, 11 Tex. TECH. L. Rev. 587 (1980).

The Federal Rules, as enacted by Congress to be effective in federal courts on July 1, 1975, are used as the paradigm of the current hearsay rule largely because of their widespread adoption (31 states and Puerto Rico) and their familiarity to most readers. Analysis of the categorical approach underlying the current hearsay rule would not significantly differ if this Article examined state decisions in statutory or common law jurisdictions rather than federal case law, except perhaps for the treatment of so-called implied assertions. See infra text accompanying notes 155-65.

21. The Federal Rules of Evidence provide 29 categorical exceptions in Rules 803 and 804. Rule 804 combines the justification of necessity, due to the unavailability of the declarant, with guarantees of trustworthiness. See McCormick, supra note 2, at 753 n.6. The residual hearsay exceptions, an innovation of the Federal Rules of Evidence, depart from the categorical tradition. Rules 803(24) and 804(b)(5) are applicable only on an individualized, case-by-case basis. Id.; see also id. at 407. Rule 801(d) provides eight exemptions from the definition of hearsay. These exemptions are categorical in nature and refiect, to some extent, the policies of reliability and necessity.

22. As the court in United States v. DiMaria, 727 F.2d 265, 272 (2d Cir. 1984), stated:

The scheme of the Rules is to determine that issue [the credibility of hearsay declarations] by categories; if a declaration comes within a category defined as an exception, the declaration is admissible without any preliminary finding of probable credibility by the judge, save for the 'catch-all' exceptions of Rules 803(24) and 804(b)(5) and the business records exception of Rule 803(6). ... As Judge Weinstein has stated, 'the scheme adopted for the hearsay article in the federal rules is that of a system of class exceptions coupled with an open-ended provision in Rules 803(24) and 804(b)(5), ... even though this excludes certain hearsay statements with a high degree of trustworthiness and admits certain statements with a low one. 
the Federal Rules, is a claim about objective accuracy. It is generally assumed that the categorical exceptions operate "to admit evidence that has a sufficient degree of trustworthiness to promote accuracy in the factfinding process."23 The Advisory Committee's note asserts that the categories acknowledge some aspect of the declarant's circumstances, triggering a generalization about the reliability of one or more of the declarant's testimonial qualities, typically sincerity. ${ }^{24}$ These circumstances supposedly differentiate admissible hearsay from what one court has called "run of the mill" hearsay. ${ }^{25}$

Rules of evidence and procedure are routinely evaluated by their alleged effect on the accuracy of the trier's factfinding. ${ }^{26}$ The goal of accuracy posits a rational model of decisionmaking in which questions of fact, usually about unknown past events, are decided through a process

23. G. LILLY, AN INTRODUCTION TO THE LAW OF EVIDENCE 271 (1978).

24. See FED. R. Evid. advisory committee's note (stating the drafters' assumptions about the effect of circumstances on the declarant's reliability in general, and on specific testimonial qualities in particular).

One might classify and describe the assumptions underlying rule 803 as follows:

(a) Circumstances make deliberate fabrication unlikely: FED. R. Evid. 803(1) (present sense impressions), FED. R. EvID. 803(2) (excited utterances), FED. R. EviD. 803(11) (records of religious organizations).

(b) Circumstances provide motivation for truthfulness and accuracy: FED. R. EvID. 803(4) (statements for purposes of medical diagnosis or treatment), FED. R. EvID. 803(17) (market reports, commercial publications), FED. R. EvID. 803(18) (learued treatises).

(c) Circumstances at creation of document assure accuracy of declarant's memory: FED. R. Evid. 803(5) (recorded recollections).

(d) Routine circumstances and duty of accuracy make certain records reliable: FED. R. EVID. 803(6) (records of regularly conducted activity), FED. R. EvID. 803(8) (public records and reports), FED. R. EVID. 803(15) (statements in documents affecting an interest in property).

(e) Reputation concerning certain matters indicates trustworthiness: FED. R. EvID. 803(19) (reputation concerning personal or family history), FED. R. EvID. 803(20) (reputation concerning property boundaries or general history), FED. R. Evid. 803(21) (reputation as to character).

Commentators criticize certain exceptions on the ground that they provide no general guaranty of trusworthiness. See, e.g., MCCoRMICK, supra note 2, $\S 291$, at 838 (then-existing mental, emotional, or physical condition); id. at 855, 860 (excited utterances); id. at 904 (ancient doeuments); S. Saltzburg \& K. Redden, Federal Rules of Evidence Manual 829 (4th ed. 1986) (testamentary exception to general exclusion of statements of memory or belief); id. at 833 (public records and reports).

25. Fong v. American Airlines, Inc., 626 F.2d 759, 763 (9th Cir. 1980).

26. Weinstein has identified a number of other important goals of the rules of evidence and procedure, such as "economizing of resources, inspiring confidence, supporting independent social policies, permitting ease in prediction and application, adding to the efficiency of the entire legal system, and tranquilizing disputants." Weinstein, Some Difficulties in Devising Rules for Determining Truth in Judicial Trials, 66 ColUm. L. Rev. 223, 241 (1966). Yet he concludes that "[t]ruth-finding must be a central purpose." Id. at 243.

This statement places Weinstein squarely within the rationalist tradition extending from Bentham through Wigmore to the present day. See W. Twining, THEORIES of EvidencE: BENTHAM \& WIGMORE 14 (1985) ("Rectitude of decision (i.e., the correct application of valid substantive laws to facts established as true) is an important social value.") This Article also follows this tradition insofar as it participates in the debate about what kinds of evidence rules advance the goal of accuracy in factual determinations. 
of inferential reasoning. ${ }^{27}$ The trier nrakes inferences by applying general principles of knowledge and experience, "generalizations," to the evidence presented at trial. ${ }^{28}$ To the extent that the generalizations are accurate, this reasoning process could yield accurate conclusions. ${ }^{29}$ Our ideology of justice assumes that propositions of knowledge about facts can and do correspond to real events, and that from an objective point of view, a trier's decision about past facts can be described as accurate or

27. For an elaboration of this model and its assumptions, see W. TwiNING, supra note 26 , at 13-16. Rational decisionmaking about disputed facts is empirical in that the trier of fact relies on other people's firsthand knowledge of specific facts. It is rational in that the trier uses its own general background knowledge and experience to make inferences based on these specific facts.

28. 2 E. DevitT \& C. Blackmar: Federal JuRY Practice AND INSTRuCtions Civil AND CRIMINAL $\$ 72.03$, at 601 (3d ed. 1977) ("Inferences are deductions or conclusions which reason and common sense lead the jury to draw from facts which have been established by the evidence in the case."); Mansfield, Jury Notice, 74 GEo. L. J. 395, 395 (1985) ("Everyone agrees that the jury must be allowed to use some background information not formally introduced into evidence."). One purpose of such knowledge is to weigh the evidence in a case. See, e.g., Weinstein, supra note 26, at 232.

Many models of the trier's inferential reasoning exist in the literature of law and psychology. See, e.g., E. Morgan, Basic Problems of Evidence 185-87 (1962) (simple diagram conjoining the offered item of evidence with a premise); J. WEINSTEIN, J. MANSFIELD, N. ABRAMS \& M. BERGER, EvIDENCE (7th ed. 1983) (using the terminology developed for a deductive theory of proof in J. Michael \& M. Adler, The Nature of Judicial Proof (1931) and in Michael \& Adler, The Trial of an Issue of Fact, 34 Colum. L. REv. 1224, 1252 (1934)); J. WigmoRE, The SCIENCE of Judicial Proof $\$ \$ 3-26$ (3d ed. 1937) (containing an elaborate terminology to describe the process of inductive reasoning and a grand classification system for evidentiary facts); Lempert, Modeling Relevance, 75 MICH. L. REV. 1021, 1022-25 (1977) (defining a normative model of rational decisionmaking in terms of Bayes' Theorem, which utilizes a likelihood ratio to calculate the effect of new evidence on a hypothetical, completely rational decisionmaker).

Psychological models differentiate between individual "juror" and group "jury" decisionmaking. R. Hastie, S. Penrod \& N. Pennington, Inside the Jury 20-36 (1983) (describing juror reasoning as a combined process of construction, inference, and evaluation in which individual jurors construct "a credible narrative by integrating trial testimony and arguments with general world knowledge," id. at 36); see also Pennington \& Hastie, Juror Decision-Making Models: The Generalization Gap, 89 Psychological BulL. 246, 248 (1981) (defining generalizations as "factual knowledge of the social and physical world that appears relevant to the case, including concepts, facts, and relations about which the juror holds belief (although the beliefs may be mistaken), including knowledge about the effects of a certain weapon; naive psychological beliefs about motives and behavior, eyewitness memory, and alcohol and performance; or opinions about social customs among certain ethnic groups").

29. This is a tenet of the rational model. W. TwiNING, supra note 26, at 15 ("The application of the principles of induction to present evidence makes it possible to assign a probable truth value to a present proposition about a past event."). In addition to accurate generalizations, accurate conclusions require the input of relevant evidence and the exclusion of extrinsic or nonrational considerations from the decisionmaking process. See Traynor, Fact Skepticism and the Judicial Process, 106 U. PA. L. REV. 635, 640 (1958).

Researchers and scholars critical of the "optimistic rationalism" of this model, and those interested in a "holistic" approach to the link between the "logical, psychological, scientific and legal dimensions of proof," have not abandoned the philosophical assumptions of rational factfinding. W. Twining, supra note 26, at 142, 177-78; see also R. HASTIE, S. PENROD \& N. PENNINGTON, supra note 28, at 230 ("In their task of fact-finding, juries perform efficiently and accurately. . . . An evidence-driven deliberation style produces more thorough and impartial assessment and integration of the evidence."). 
inaccurate. ${ }^{30}$

The problem with this assumption is that the outcomes of adjudicative factfinding are always uncertain. There is no methodology and no objective point of view within the adjudication system to test whether the trier of fact has correctly decided the ultimate facts. ${ }^{31}$ Reexamination or de novo review of the facts by another decisionmaker would still not provide an objective version of the truth. Nor is there any point of reference outside the system to verify outcomes. Society does not make systematic comparisons between adjudicated facts and historical facts determined in some other way. Even when empirical data exists, the comparison is not necessarily conclusive. Proof of mistaken convictions, for example, rests on anecdotal types of data such as recanting witnesses or confessing wrongdoers. ${ }^{32}$ The truth is, we have no definitive objective test for the accuracy of adjudicative factfinding. ${ }^{33}$

Perhaps because of this uncertainty, two competing theories about achieving accuracy coexist in evidence law today. The external theory claims that accuracy can be increased by filtering evidence through an external set of substantive generalizations about reality before its evaluation by the trier of fact. The operational theory, on the other hand, claims that accuracy is maximized by the trier's ability to apply its own generalizations about reality to determine the probative value of evi-

30. This correspondence theory of truth is likely due to the retrospective nature of judicial conduct. Weinstein, supra note 26, at 229 ("Even when designed to affect future conduct, judicial determinations must be based upon assumptions with respect to past events. The court is required to assume the role of historian-without the historian's opportunity to reserve decision."); see also Hart \& McNaughton, Evidence and Inference in the Law, 87 DAEDAlus 40, 42 (Fall 1958).

31. Systematic reexamination of the trier's factfinding is prevented by doctrines of res judieata and collateral estoppel. Constitutional and procedural rules defer to the institutional capacity of the trier of fact and restrict appellate review of facts. The seventh amendment to the United States Constitution provides that "no fact tried by jury, shall be otherwise examined . . . than according to the rules of the common law." U. S. CoNSr. amend. VII. Even judicial decisions to direct verdicts and enter judgments n.o.v. must defer to the role of the trier of fact. See, e.g., Boeing Co. v. Shipman, 411 F.2d 365, 374-75 (5th Cir. 1969) (en banc); F. James \& G. Hazard, Civil. Procedure $\$ 7.22$, at 403-05 (3d ed. 1985); Cooper, Directions for Directed Verdicts: A Compass for Federal Courts, 55 MinN. L. REV. 903 (1971).

A trial court can, of course, grant a motion for thew trial where, in its view, the verdict is "against the weight of the evidence." 6A J. MOORE, J. LuCAS \& G. Grotheer, FederAL. Practice \{ 59.04[5], at 59-20 (2d ed. 1986). This judicial control of factinding does not amount to de novo review or reconsideration of disputed facts. Rose Hall Ltd. v. Chase Manhattan Overseas Banking Corp., 576 F. Supp. 107, 124 (D. Del. 1983), aff'd, 740 F.2d 958 (3d Cir. 1984), cert. denied, 469 U.S. 1159 (1985).

The scope of appellate review of factfinding is also restricted by deference to the jury and to the opportunity of the trial judge to determine credibility. F. JAMES \& G. HAZARD, supra, at 667-68.

32. Gross, Loss of Innocence: Eyewitness Identification and Proof of Guilt, 16 J. LEGAL. STUD. 395 (1987).

33. Some social science research has approached the problem of verification by checking jury verdicts against how the trial judge would have decided the same case. See, e.g., H. KALVEN \& H. ZEISEL, The AMERICAN JURY 45-54 (1966). But this comparison does not guarantee that the result reached by either decisionmaker is accurate. 
dence. Thus, both theories rest their claim of increasing accuracy on the use of generalizations, but from different sources. ${ }^{34}$

The categorical approach to admitting hearsay relies on the use of external generalizations. The categorical exceptions are substantive generalizations not formulated by the trier of fact, but drafted by judges and legislators to represent their collective beliefs about what kinds of hearsay statements are more likely to be reliable. All hearsay that does not conform to these generalizations about reliability is excluded from the trier of fact.

However, there is little support for the claim that the categorical approach admits individual items of hearsay that are more reliable than the items it excludes. First, the categorical generalizations about what enhances the reliability of hearsay are unvalidated. ${ }^{35}$ We lack systematic empirical research about how the testimonial circumstances of declarants actually affect reliability. The research conducted on a few exceptions flatly contradicts their underlying assumptions about enhanced reliability of perception, memory, and sincerity. ${ }^{36}$ In addition, the reliability of any given item of hearsay in a particular case cannot be proved objectively.

34. The operational theory assumes that the trier's own general knowledge and experience are the best source of generalizations to make the inferences necessary to evaluate the reliability and probative value of individual items of evidence. Rules adopting this approach strive to admit evidence that enhances the trier's ability to apply generalizations, which in turn should increase the likelihood of accurate factfinding. The rules requiring the questioning of witnesses in front of the trier, and the minimalist tests of logical relevance and authentication typify this operational approach to legal regulation of proof. See Note, The Hearsay Rule and Epistemological Suicide, 74 GEO. L. J. 1301, 1308-09 (1986) (analyzing evidence rules in terms of judicial concern that the jury have some means to evaluate evidence). The foundation fact approach to the admission of hearsay exemplifies the operational approach as well. See Mansfield, supra note 28, at 413-19 (discussing how judicial notice, legal presumptions, and exclusion of evidence on grounds of irrelevance can give effect to external generalizations emanating from judges and legislators rather than permitting the trier of fact to apply freely its own general knowledge and experience).

35. Generalizations about hearsay declarants cannot be classified under the standards of accuracy established by Mansfield, supra note 28, at 413-19. The generalizations about reliable testimonial qualities underlying most of the categorical exceptions cannot possibly qualify as appropriate for judicial notice. They do not have the probative force of generalizations imposed upon the trier in the form of legislative or judicial presumptions. Unlike events controlled by laws of nature, or subject to objective verification, any hearsay declarant can be reliable or unreliable regardless of how the categorical exceptions characterize her testimony. The exceptions do not correspond to real beliefs held by real people about real declarants. No trier of fact would make a judgment about reliability based on such broad and abstract characterizations.

36. The empirical research available on the hearsay exceptions for dying declarations, state of mind, and spontaneous and contemporaneous utterances illustrates these contradictions. See, e.g., Hutchins \& Slesinger, Some Observations on the Law of Evidence, 28 CoLum. L. REv. 432, 436-38 (1928); Hutchins \& Slesinger, Some Observations on the Law of Evidence-State of Mind to Prove an Act, 38 YALE L.J. 283, $295-96$ (1929); Jaffee, The Constitution and Proof by Dead or Unconfrontable Declarants, 33 ARK. L. Rev. 227, 308-63 (1979); Stewart, Perception, Memory, and Hearsay: A Criticism of Present Law and The Proposed Federal Rules of Evidence, 1970 UTAH L. REV. 1, 27-29; Sivanson, The Law of Res Gestae and Considerations of Perception, 49 INs. Couns. J. 381, 384 (1982). 
Just as there is no objective point of view to verify the accuracy of outcomes, there is no systematic way to match individual hearsay statements against a verified account of what actually happened. Moreover, categorical exceptions, particularly as liberalized by the Federal Rules of Evidence, do not admit perfectly reliable hearsay. ${ }^{37}$ General categories will always contain particular instances that are marginal or ambiguous. Categorical terms that are broad and abstract, and hence applicable to a broad range of statements, can include both reliable and unreliable statements. ${ }^{38}$ Further, the Federal Rules based inany exceptions on generalizations about only one testimonial quality-sincerity. ${ }^{39}$ Circumstances that supposedly affect sincerity leave the reliability of the declarant's perception in great doubt, and vice versa.

Still worse, the categorical approach frustrates the function of the trier of fact. As stated above, the categorical exceptions necessarily admit hearsay of dubious quality. Yet the trier still has to draw inferences about the declarant's testimonial quahities to evaluate each iten.. ${ }^{40}$

37. "The large variation in reliability of hearsay admissible under the various exceptions has been devastatingly demonstrated by Morgan and others and needs no further discussion among experienced attorneys." Weinstein, Alternatives to the Present Hearsay Rules, 44 F.R.D. 375, 379 (1968); see also E. Morgan, Some Problems of Proof Under the ANglo-American System OF LITIGATION 169-95 (1956).

See, e.g., Comment, Ancient Documents as an Exception to the Hearsay Rule, 33 YALE L.J. 412, 417 (1924); Note, Dealing With the Problem of Unreliable Evidence Admitted Under a Literal Interpretation of Federal Rule of Evidence 803-18, 14 VAL. U.L. REV. 329, 339-40, 342, 346 (1980) (interpretation of term "science," writings, and expert testimony regarding writings) [hereinafter VAL. U.L. REv. Note]. See generally Morgan, The Relation Between Hearsay and Preserved Memory, 40 HARV. L. REv. 712 (1927) (listing and criticizing various hearsay exceptions); Stewart, supra note 36 (empirically challenging reliability of exceptions for excited utterances, present sense impressions, statements of a then-existing mental or physical condition, and statements for purposes of medical diagnosis).

The Federal Rules liberalized a number of hearsay exceptions, making them more problematic and less generically reliable. FED. R. EvID. 803(4), 803(6), 803(8)(C), 803(18), 804(b)(1), 804(b)(2), 804(b)(3), 804(b)(4), \& advisory committee's notes; Stewart, supra note 36; Note, The Scope of Federal Rule of Evidence 803(8)(C), 59 TEX. L. REV. 155 (1980); VAL. U.L. REv. Note, supra.

38. For example, rule $803(6)$, the categorical exception for business records, has been applied to admit a wide range of items. See, e.g., United States v. Kasvin, 757 F.2d 887, 892 (7th Cir.) (admitting records of drug sales despite testimony they "were made by persons who may have been under the influence of coeaine," probably "contained errors," and " that there was no consistency of records as ordinarily found or supposed to be found in a legitimate business" "), cert. denied, $106 \mathrm{~S}$. Ct. 592 (1985); United States v. Licavoli, 604 F.2d 613, 622 (9th Cir. 1979) (admitting appraisal of stolen painting prepared for insurance claims adjustment purposes with no qualification of the appraiser as an expert witness), cert. denied, 446 U.S. 935 (1980); United States v. Reese, 568 F.2d 1246, 1252 (6th Cir. 1977) (admitting scrapbook of newspaper clippings kept by hospital employees to prove the hospital's visiting hours).

39. See supra note 24 .

40. See, e.g., United States v. DiMaria, 727 F.2d 265, 271 (2d Cir. 1984) ("if [defendant's exculpatory statement] fell within Rule 803(3), as it clearly did if the words of that Rule are read to mean what they say, its truth or falsity was for the jury to determine"); sec also United States v. Harris, 733 F.2d 994, 1004-05 (2d Cir. 1984); Ladd, The Relationship of the Principles of Exclusionary Rules of Evidence to the Problem of Proof, 18 MINN. L. REv. 506, 509-16 (1934). 
In order to make inferences, the trier needs facts about declarants and the circumstances affecting their perception, memory, sincerity, and use of language. But the only facts that the proponent of hearsay must produce in an actual case are those that prove that the item of hearsay conforms to the categorical exception. This information, as Part IV demonstrates, does not necessarily address the trier's problem of evaluation.

Once these adverse effects on the trier's evaluation are recognized, the only basis for claiming that the categorical approach increases accuracy is a belief that the substantive generahizations imposed on the trier by the exceptions are simply more accurate than the generalizations the trier would apply on its own. But lacking verification, this belief bankrupts the categorical approach. The legal profession's complacency about the current hearsay rule reflects subjective impressions about what hearsay categories are intrimsically reliable enough to help reliable outcomes. The profession then beheves that the categories are valid because the outcomes are accurate. ${ }^{41}$ The categorical approach is a closed system that can neither be validated nor spontaneously expose its own shortcomings.

Some commentators propose abohishing the hearsay rule, contending that there are no objective standards of accuracy that judges are competent to enforce. ${ }^{42}$ Others agree that the hearsay rule cannot increase accuracy, but have formulated an apologia for the rule based on its effect on the public's acceptance of verdicts after trial. ${ }^{43}$ The abolitionists and

41. One example of this circular reasoning is the Commonwealth Fund Special Committee's investigation of the hearsay exception for statements of deceased persons made in good faith prior to the action. The Massachusetts bar's satisfaction with the exception was based on its belief in accurate outcomes. See E. MORGAN, supra note 11, at 39 (conceding that, "There exists no body of data from which it can be demonstrated whether any or all the exceptions to the hearsay rule help or obstruct the search for truth.").

42. See, e.g., James, The Role of Hearsay in a Rational Scheme of Evidence, 34 U. ILL. L. REv. 788, 794 (1940); Smith, The Hearsay Rule and the Docket Crisis: The Futile Search for Paradise, 54 A.B.A.J. 231, 235-37 (1968); Younger, Reflections on the Rule Against Hearsay, 32 S.C.L. REV. 281, 291-93 (1980); Note, The Theoretical Foundation of the Hearsay Rules, supra note 18, at 1815; Comment, Abolish the Rule Against Hearsay, 35 U. P1TT. L. REv. 609 (1974).

43. The most elaborate of such theories, proposed by Professor Charles Nesson, attempts to justify the hearsay rule by its purported effect on the stability of verdicts. Nesson, The Evidence or the Event? On Judicial Proof and the Acceptability of Verdicts, 98 HARV. L. REV. 1357 (1985); see also Note, supra note 18, at 1807-14. Nesson's stability theory holds that limiting the use of hearsay protects verdicts against turncoat, reeanting declarants. However, his claim that hearsay exceptions actually admit statements that declarants will either not recant, or that will not be affected by recantation, is simply unsupported.

Park's critique of Nesson's theory points out that the exclusion of hearsay actually presents a serious threat to the general acceptance of verdicts. Under Nesson's theory, the reappearance of any excluded declarant could substantially challenge a verdict. Hence, a policy completely consistent with Nesson's theory would require both the admission of all statements of deceased declarants and the testimony of all available declarants. Park, supra note 4, at 1064-66.

Moreover, Nesson's broader theory of evidence law is a legal nightmare. It focuses on what 
apologists are correct that the categorical approach undermines the central justification for the current hearsay rule. But this critique does not leave one with the dismal choice of either abolishing or apologizing for the hearsay rule. As an alternative, a foundation fact approach to hearsay and the values it implements must be considered.

\section{II}

\section{The Foundation Fact APproach IN THEORY}

The values of operational accuracy, independence, and fairness legitimate the results of adjudicative factfinding because they effectuate the functions performed by the participants in trials. The trier of fact evaluates the proof presented to it about disputed questions of fact on the basis of its own general knowledge and experience. The proponent of evidence submits proof, chosen from the widest range of accessible potential proof. The opponent challenges the proponent's sources of proof. Operational accuracy enhances the trier's ability to evaluate proof. Independence increases the trier's freedom from substantive governmental controls on the use of its own general knowledge and experience. Fairness imposes a basic obligation on the proponent to make sources of proof accessible for challenge at trial, and adjusts this obligation when it would be unfair to the proponent.

While a foundation fact approach to the admission of hearsay implements these values, the categorical approach of the current hearsay rule actually subverts them. The objective, categorical generalizations about reliability that the current rule imposes on the trier undermine the operational accuracy and independence of the trier, and the hearsay that is admitted unfairly denies opponents access to the proponents' sources of proof at trial.

Part II describes the foundation fact approach and formulates a workable standard for the admission of hearsay. It then shows why this approach is preferable to the current categorical rule in terms of solving the problems of hearsay and serving the values of operational accuracy, independence, and fairness.

persuades the public to accept a verdict as a decision about real events, rather than on what enables the jury to decide that a real event took place. What empirical tools do judges have to gauge the public's acceptance of various kinds of evidence as proof that events occurred? Speculation about what pleases the public could vary from case to case and from public to public. Should judges abandon all other standards of admission if they discover what the public will accept? Public and political demand for wider admission of a criminal defendant's prior convictions is just one example of the problems with this theory. Cf. People v. Castro, 38 Cal. 3d 301, 696 P.2d 111, 211 Cal. Rptr. 719 (1985). 


\section{A. The Basic Standard: The Requirement that the Proponent Produce a Knowledgeable Process Foundation Witness}

The foundation fact approach focuses on the trier of fact's problem of deciding whether to rely on what declarants claim to know about relevant facts. The final decision about reliability will be the result of a confluence of inferences about all of the evidence presented in the case. But it is well established in hearsay scholarship that inferences about the declarant's perception, memory, sincerity, and language use are important factors in this decision. ${ }^{44}$

Information about the declarant and the circumstances that influenced her when she perceived, remembered, and spoke about the relevant facts help the trier draw these inferences. This Article refers to this information as "foundation facts," as distinguished from case-specific "evidentiary" facts that go to the merits of the dispute. Foundation facts are relevant to the merits, but only indirectly: they affect the likelihood that the declarant's statement is or is not reliable.

To illustrate the relevance of foundation facts, consider a lawsuit arising out of a bus accident. The proponent offers the hearsay statement of a declarant who said, "I saw that bus driver drive straight through the stop sign." Foundation facts-such as where the declarant was standing when the accident occurred and whether she was paying attention-are relevant to evaluating the reliability of the declarant's perception. Information about the lapse of time between the declarant's perception and statement is relevant to the declarant's memory. And facts about the declarant's identity and audience when speaking are relevant to sincerity.

The foundation fact approach produces information relevant to evaluating the declarant's testimonial quahities. Unlike the categorical approach, it does not depend on externally imposed generalizations that supposedly enhance the declarant's reliability. Some hearsay commentary recognizes that the problem of hearsay is its evaluation, and not necessarily its untrustworthiness. ${ }^{45}$ But the categorical exceptions, based

44. E. MORGAN, supra note 28 , at 245 ; J. WIGMORE, supra note 28 , $\$$ 170-71; Weinstein. supra note 6 , at 332-34. Other writers emphasize that other evidence in the case can also influence the trier's evaluation of a declarant's (or a witness') reliability. See, e.g., Lempert, supra note 28, at 1053-54 (discussing the influence of cumulative evidence and presenting criteria for its identification). Nevertheless, the probative value of hearsay depends primarily on specific aspects of the declarant's behavior: whether the declarant used appropriate language (including connotations of particular words and phrases), whether the declarant spoke sincerely, whether the declarant accurately perceived the relevant event when it occurred, and whether the declarant accurately remembered what she once perceived.

45. See, e.g., FED. R. EvID. art. VIII, Introductory Note: The Hearsay Problem (Preliminary Draft), 46 F.R.D. 161, 327 (1969) ("The only way in which the probative force of hearsay differs from the probative force of other testimony is in the absence of oath, demeanor, and crossexamination as aids in determining credibility." (emphasis added)); G. LILLY, supra note 23, at 271 (whether accurate factfinding is advanced depends in part on "the extent to which the trier ean be 
on generalizations about reliability, conflate the two concerns. In contrast, the foundation fact approach addresses the problem of evaluation, and leaves the problem of reliability to the trier of fact. ${ }^{46}$

Foundation facts produced when a witness testifies offer a standard for determining what facts the adjudication system considers necessary to evaluate testimony. First, the circumstances in the courtroom when the witness is speaking are foundation facts relevant to the witness' use of language ${ }^{47}$ sincerity, ${ }^{48}$ and memory ${ }^{49}$ The trier observes these circumstances and the witness' behavior while testifying, which may yield additional facts that affect evaluation. ${ }^{50}$ Second, specific circumstances outside of court-such as the setting, the declarant's own location and

alerted to [hearsay's] possible infirmities"); Note, supra note 34, at 1307 ("the proper focus in the area of hearsay is not reliability but the means of determining how much weight should be accorded any hearsay statement").

46. The question whether hearsay should be excluded because it cannot be cvaluated is different from the question whether hearsay should be excluded because it lacks adequate reliability. Other commentators erroneously conflate the two questions. See, e.g., McCoRMICK, supra note 2, $\S 252$, at 752 ; James, supra note 42 , at 794 (equating the difficulty of evaluating hearsay with the problem of placing a proper value on questionable hearsay); Lilly, Notes on the Confrontation Clause and Ohio v. Roberts, 36 U. FLA. L. REV. 207, 228 n.115 (1984) ("the ability of the trier to evaluate the credibility of the hearsay evidence should turn in large part, if not exclusively, upon the presence or absence of indicia of reliability.").

Most scholars who recognize the preeminence of evaluation offer no way to address this problem without imposing external generalizations about reliability. For example, Morgan proposed a test for admitting hearsay that recognizes the difference between a foundation fact approach and a categorical approach in part (a), but interjects judicial generalizations about reliability in part (b): "(a) whether the hearsay is such that the trier can put a reasonably accurate value upon it as evidence of the matter it is offered to prove, (b) whether direct testimony of the declarant is unavailable or, if available, is likely to be less reliable." E. MoRGAN, supra note 28, at 254 (emphasis added); see also R. LEMPERT \& S. SALTZBURG, A MODERN APPROACH To EVIDENCE 598-99 (2d ed. 1982) (proposing a standard under the Confrontation Clause in criminal cases for a foundation "sufficient to warrant an inference that the statement is true," but also recognizing that the foundation should also "enable the jury to assess [the hearsay statement's] weight"); Comment, supra note 42, at 624-26 (emphasizing the importance of information from a foundation witness for the evaluation of hearsay, but offering no standard for admission to insure the availability of this information); Note, supra note 34, at 1310 (arguing that the focus of the hearsay rule "should be on what is known about any particular hearsay statement and whether it is enough to draw a conclusion about the accuracy of the statement," but conceding that the author "does not attempt to resolve what constitutes an adequate basis for evaluation.").

47. For example, the witness speaks in response to the language used in the lawyer's questions. If the lawyer defines words, or puts them in context ("Was she very tall? By very tall, I mean over six feet"), it may affect the witness's use of language.

48. Courtroom circumstances also reveal the witness's motive and opportunity to be truthful. She says she will honor her duty to speak the truth. She may fear discovery of a lie through crossexamination, or she may fear the penalty of perjury. She may know which party is relying on her testimony and how it may affect the outcome. All of the circumstances made known to the trier can affect evaluation, whether they seem to affect reliability positively or negatively.

49. Refreshing the witness's recollection may generate foundation facts which can be used in generalizations about the actual accuracy of the witness's memory.

50. Calmness, nervous behavior, aggressiveness or a reluctance to answer questions are characteristics that the trier might think relevant. The variety of such facts is enormous. Indeed, 
opportunity to observe, and the lapse of time since the event or pretrial preparation-are facts relevant to perception and memory. The witness must answer questions about these circumstances if asked. Finally, facts about the witness' identity, imcluding her relationship to the lawsuit, are gained through observation and questioming, and are relevant to all four testimonial qualities. ${ }^{51}$

The same types of facts are relevant to the trier's evaluation of a declarant's reliability. First, when a hearsay declarant makes a statement out of court, the circumstances then existing establish the context within which to evaluate the declarant's use of language and sincerity, and perhaps memory and motive as well. ${ }^{52}$ Second, the specific circumstances existing when the declarant perceived and remembered the relevant event before speaking about it are relevant to evaluating perception and memory. ${ }^{53}$ Finally, facts about the declarant's identity, relationship to the parties or to the case at issue, general testimonial qualities, and behavior

the only relevant characteristic that the trier does not observe is the specific exercise of perception that took place in the past.

Moreover, some of the witness' general and specific testimonial qualities can be tested right in front of the trier. Mistakes, idiosyncracies, and ambiguities in speech can be tested on the spot by asking the witness what she means. Perception can be tested by asking the witness to perform perceptual tasks (such as reading a sigu across the courtroom, identifying specific colors, or listening to specific sounds). Memory could be tested if there were objective agreement as to what would constitute the right result. The need for memory refreshment is itself relevant to the trier's evaluation.

The witness's sincerity is less amenable to testing. Tests that disclose the mental state that accompanies lying have eluded scientists and cross-examiners for centuries. The only concrete demonstration of insincerity is a witness who renounces the lie she has already told in court, but renunciation occurs rarely.

51. The witness' name, address, and occupation identify her generally to the trier. Details about the witness's appearance, dress, behavior, manner of speaking, and responsiveness manifest themselves in court. The trier of fact can use these background facts to evaluate all testimonial qualities.

The adversaries may inquire about the witness's habits, including her use of language and physical capacities, which might be relevant to perception and memory. Questions related to special experience or training that affect these testimonial qualities are also relevant. Questions to the witness about her general character for honesty, however, are not permitted. FED. R. EviD. 608(a)(2). But see FED. R. EvID. 608(b) (specific acts that show an untruthful character may be the subject of cross-examination and may be used by the jury to evaluate truthfulness). Questions about special relationships or specific interests that affect sincerity are also permissible. See United States v. Abel, 469 U.S. 45 (1984).

52. Some courts explicitly acknowledge the value of foundation facts about the circumstances in which a declarant made a statement. For example, one court admitted a Treasury Department claim form under the residual exception. United States v. White, 661 F.2d 531, 538 (5th Cir.) ("Hess, who helped prepare the [declarant's] statement and who had personal knowledge of many of the facts it contained, was available for cross examination regarding the circumstances surrounding the execution of the claim form and the facts giving rise to the filing of the claim."), cert. denied, 446 U.S. 992 (1980).

53. See, e.g., Hilyer v. Howat Concrete Co., 578 F.2d 422, 424, 427 (D.C. Cir. 1978) (issue concerning declarant's opportunity to perceive was for the jury to decide, despite declarant's subsequent assertion that he had not even seen the accident in question). 
when perceiving, remembering, or speaking may also be relevant. ${ }^{54}$

The key to obtaming these analogous foundation facts is to introduce hearsay to the trier through a knowledgeable foundation witness. A foundation witness is anyone, including the declarant, who knows about the same types of foundation facts the trier can learn when a witness testifies. This insight can be translated into a general principle of admissibility under the foundation fact approach to hearsay: The proponent of a hearsay statement is obligated to produce a process foundation witness knowledgeable about the circumstances at the time the declarant perceived, remembered, and made her statement. This basic standard of admissibility presents information relevant to evaluating the specific statement on the basis of all four of the declarant's testimonial qualities. The entire process foundation usually can be produced through one, or perhaps two, foundation witnesses, as in the following four examples.

Example 1. A bus accident occurred in an intersection controlled by a stop sign. The bus hit a car, and several people were injured. The driver of the car claims that the bus did not stop at the stop sign. The bus driver claims that she did. The injured victims sue the bus company. A woman who witnessed the collision said to her husband later that day, "I saw the bus driver drive straight through the stop sign." At trial, the same woman appears in court to testify about the accident and about making her prior statement to her husband.

The woman in this Example can provide a process foundation for her own hearsay statement: she can describe where she was standing and what she was doing when she perceived the collision. She can relate when and why she made her prior statement. And of course she can answer additional questions about all these circumstances. The declarant who serves as a foundation witness, like this woman, is usually the most knowledgeable source of foundation facts. Current evidence law may prefer declarants who appear as witnesses to testify about their memory of events like the bus accident, rather than about their memory of their own hearsay statements, but sometimes it permits both. ${ }^{55}$

Example 2. In the bus accident case, an unidentified declarant at the

54. The interest of the declarant in making the statement is often related to the declarant's job or role, and this interest may be quite probative of accuracy and sincerity. See, e.g., Donovan v. Crisostomo, 689 F.2d 869, 877 (9th Cir. 1982); United States v. Vacca, 431 F. Supp. 807, 812 (E.D. Pa. 1977), aff'd, 571 F.2d 573 (3d Cir. 1978).

55. Admission of a testifying witness' prior out-of-court statements consistent with her testimony is regulated by the concept of cumulativeness. See M. GraHAM, Evidence 127-30 (1983); Waltz, The Present Sense Impression Exception to the Rule Against Hearsay: Origins and Attributes, 66 IowA L. REv. 869, 881 (1981) (contending that present sense impressions of a testifying witness are not cumulative.)

Under the Federal Rules, the statement in Example 1 does not fall within any traditional categorical exception and it does not qualify under rule 801 (d) as a statement of a testifying witness. Thus, it would be excluded. 
scene of the accident said, "That bus driver drove straight through the stop sign." The foundation witness is a bystander who was standing near the declarant at the scene of the accident. The bystander testifies that she and the declarant were both waiting and watching for the bus just before the accident; that she herself was looking the other way when the collision occurred; and that she heard the declarant make the hearsay statement immediately afterward.

The bystander in this Example can provide a process foundation for the declarant's statement. She observed the declarant's location and other specific circumstances when the declarant perceived, remembered, and made a statement about the bus accident. ${ }^{56}$ No facts about the identity of the declarant are presented. If the bystander knows the declarant, such facts are, of course, relevant. If not, the declarant may remain unidentified. When process foundation facts relevant to all four of the declarant's testimonial qualities are available, anonymous hearsay can be evaluated and should be admitted. If the declarant had made the statement about the accident some time after perceiving it, an additional foundation witness might be needed to complete the foundation. ${ }^{57}$

Example 3. In the bus accident case, the declarant is a doctor who made a statement on an office chart that "bus driver's eyesight is 20/20." The foundation witness is the doctor's office supervisor, who testifies about how charts are kept in the office, and that the doctor records her opinions only after giving certam examinations pursuant to an established routine.

The office supervisor can provide a process foundation for the doctor's hearsay statement. The supervisor is knowledgeable about the circumstances that usually affect the doctor's perceiving, remembering, and making a recorded statement about the driver's eyesight. This Example shows that the foundation witness may be someone who knows about a job, a public or private duty, or other general circumstances affecting the testimonial qualities of the declarant.

Example 4. In the bus accident case, multiple declarants have made a recorded hearsay statement that the bus involved was inspected a week before the accident and that its brakes were in good working order. The foundation witness is the bus company's service manager, who testifies that, according to company routine, an original declarant inspects the brakes and reports the results to the reporting declarant, who writes the inspection report and dates it.

Here, the service manager can provide a process foundation for the

56. The statement in Example 2 would be admitted today under rule $803(1)$ as a present sense impression. See, e.g., Houston Oxygen Co. v. Davis, 139 Tex. 1, 5-6, 161 S.W.2d 474, 476 (1942). Even if the bystander had also observed the bus at the stop sign, she could still testify about the hearsay statement she overheard. The probative value of corroborative hearsay can be substantial.

57. If the time elapsed between perception and speaking is significant, the statement would be excluded under rule $803(1)$, no longer qualifying as a present sense impression. But see infra note 204. 
recorded statement. The manager is knowledgeable about two declarants. She can testify about circumstances that affect the original declarant's perception of the brakes and her statement to the reporting declarant, and about the reporting declarant's making of a record based on that statement. Again, even if the two declarants are not identified, facts about the circumstances affecting their testimonial qualities permit evaluation of their statements. ${ }^{58}$

In all four examples, admission of the hearsay depends on the proponent's production of a knowledgeable process foundation witness. The trial judge decides whether the qualifications of this foundation witness must conform to the basic requirements of the foundation fact approach and to current principles of evidence law. In terms of content, the testimony of a process foundation witness must relate to the three process circumstances described above. First, foundation testimony must show that the declarant was a percipient witness, or "one who was in a position to perceive the event or condition which his declaration purports to describe."59 Proving the declarant's perception opportunity is an essential part of a foundation for hearsay. ${ }^{60}$ Second, circumstances pertinent to the declarant's memory of the relevant event or condition must be shown. This requirement is normally satisfied by testimony that shows the time elapsed between the perception and the statement. But if special factors intervene, such as memory refreshment prior to the making of the statement, they must be included in the foundation. ${ }^{61}$ Third, foundation testimony must describe the circumstances when the declarant made the hearsay statement. The context in which the statement was made affects both language use and sincerity.

The trial judge must also test the extensiveness of the foundation witness' knowledge. The trial judge could apply a standard that is already used in the Federal Rules of Evidence: the process foundation witness must have sufficient recollection "to enable him to testify fully and accurately" about the declarant's circumstances. ${ }^{62}$ A crucial characteristic of a knowledgeable foundation witness is that she be subject to

58. Both the written statements in Example 3 and Example 4 could be admitted as business records under the categorical approach of rule 803(6), which requires the testimony of a custodian of the records. See infra note 186.

59. Waltz, supra note 55 , at 877 .

60. Firsthand knowledge of events and conditions is required of all witnesses under rule 602 . The same prerequisite should extend to hearsay declarants. Waltz calls this requirement "a matter of testimonial competence." Waltz, supra note 55, at 878 .

61. An additional foundation witness would not be necessary in the obvious situations ivhere memory refreshment occurs: prior testimony and prepared statements. Usually the person knowledgeable about the making of such a statement will also know about the declarant's preparation. Otherwise, establishing the time lapse between the perception of the event and the statement about it requires no additional foundation witness.

62. FED. R. EvID. 803(5). This standard, adopted in the exception for past recolleetion 
cross-examination. This provides the opponent with a fair opportunity to test the witness' knowledge by inquiring about additional facts. ${ }^{63} \mathrm{~A}$ knowledgeable foundation witness, tested by the above qualifications and questioned by both parties, can generate foundation facts analogous to the kinds of facts available to the trier of fact when a witness testifies.

Examples 1-4 all involve simple forms of hearsay: declarants making statements about disputed facts in the context of their everyday lives. The basic standard of admission is easy to apply in these situations. But relevant hearsay statements are generated in a wide variety of more complicated circumstances. Adjustments can be made in the basic standard of admission to reflect these complexities. I describe these adjustments in Part III. Before doing so, however, I first discuss why the values of operational accuracy, independence, and fairness justify the basic foundation fact approach to admission.

\section{B. The Underlying Values}

\section{Operational Accuracy: Evaluating Hearsay by the Trier's General Knowledge and Experience}

The goal of achieving accurate outcomes should not be the sole basis for choosing evidence rules smce it cannot be ever determined which rules produce accurate outcomes, or even rehable items of evidence. However, accuracy is a powerful societal expectation for our system of justice. Adjudicative factfinding is treated as if it were true, despite all uncertainties. ${ }^{64}$ Thus, debate about theories of accuracy are important.

This Article argues that a theory of operational accuracy should

recorded, is used to test a witness's memory of a relevant event. Failed memory is a prerequisite for application of rule 803(5).

In contrast, failed memory should disqualify a foundation witness. For example, a foundation witness cannot be qualified as "knowledgeable" if she is "reluctant," "uncooperative," or a "stone wall." See United States v. Campbell, 684 F.2d 141, 146 (D.C. Cir. 1982). A fiat claim of loss of memory should also disqualify her. See, e.g., United States v. Ray, 768 F.2d 991, 994-95 (8th Cir. 1985), cert. denied sub nom. Felton v. U.S., 107 S. Ct. 3235 (1987). If a witness "becomes vague or evasive or claims he cannot remember a particular aspect of the event in question," his memory should be deemed insufficient to form a foundation. Cf. $4 \mathrm{~J}$. WEINSTEIN \& M. BERGER, supra note 12 , I 803(5)[01], at 803-159.

63. The trial judge's discretion has historically included "the power to strike the testimony of a witness who improperly refuses to answer questions on cross-examination." United States v. Panza, 612 F.2d 432, 438 (9th Cir.) (citing 5 J. WIGMORE, supra note 2, at $\$ \S 1364,1390$ and MCCoRMICK, supra note $2, \S 19$ ), cert. denied, 447 U.S. 925 (1980). A court may refuse to allow cross-examination only if "the jury is otherwise in possession of sufficient information upon which to make a discriminating appraisal of the subject matter at issue." Skinner v. Cardwell, 564 F.2d 1381, 1389 (9th Cir. 1977), cert. denied, 435 U.S 1009 (1978).

64. Nonrational influences do operate on the trier of fact. See Weinstein, supra note 26, at 23236, 237-39 (discussing unconscious and conscious distortions of the trier's factfinding process); infra text accompanying note 81 . The aim of evidence rules should be to maximize the trier's potential for rational factfinding. 
underlie evidence rules. The premise of this theory is that because we are unable to get behind the evidence presented to the trier, accuracy inheres in the process of the trier applying its own general knowledge and experience to evaluate evidence. ${ }^{65}$ Rules that maximize the trier's ability to apply its general knowledge and experience serve the value of operational accuracy. This view of accuracy already informs much of modern evidence law, and should apply to the hearsay rule as well.

The decision whether or not to rely on what people say is a common experience, encountered in everyday life as well as in trials. The general knowledge of the jury members or the judges who serve as the trier of fact derives from such ordinary daily experiences. Experience that relates to the reliability of testimonial qualities is gained from observing a person's behavior, her characteristics, and the specific circumstances affecting her. ${ }^{66}$ The trier's knowledge also has been tested in the real world by actual reliance on what other people say and do. The rational decisionmaker applies generalizations from this experience to evaluate the reliability of what a person claims to know about something like a bus accident. ${ }^{67}$ This application process probably occurs unconsciously and virtually instantaneously most of the time, so it is impossible to articulate all the general knowledge that may feed a single conclusion. ${ }^{68} \mathrm{Nev}$ ertheless, it seems plausible to use the concept of applying generalizations to account for why we think decisionmaking can be rational. Both evi-

65. All factfinders must apply their general knowledge and experience to evaluatc proof. A trier of fact, whether juror or judge, is supposed to use individual background knowledge as the basis for inferences.

66. For example, experience may teach that "people who respond automatically to questions" probably have a good memory; or, "people who are nervous" probably are insincere. Particular characteristics such as age, occupation, or education may relate to character traits that in turn relatc to testimonial qualities. Experience may cause the trier to believe, for example, that "school teachers are careful observers of written documents," or that "bus drivers always exaggerate their own carefulness." Evidence law does not preclude the trier from using information about such general testimonial attributes, even character for truthfulness, as a basis for inferences about testimonial reliability. In contrast, evidence law disfavors using generalizations about character to draw conclusions about specific disputed instances of conduct. FED. R. EvID. 404(a). Finally, a person who witnesses a bus accident may have an unobstructed view, but may not be paying attention. These kinds of circumstances relate to the trier's ordinary experience with perception.

67. Evaluation of credibility is always based on circumstantial reasoning. Weinstein, supra note 6, at 333 ("Since no one can read another man's mind or judge his capacities directly, evidence of specific credibility, including demeanor, is always circumstantial . . ..").

68. Current scholarship is exploring the "complex 'web of belief' that typically constitutes the background knowledge on which we base our judgements [sic]." W. TwiNING, supra note 26, at 148; see also W. BENNETT \& M. FeldMan, Reconstructing ReAlity IN THE Courtroom 50 (1981)("various types of background understandings . . can enter into the interpretation of social action: empirical knowledge, language categorization, logical operations, norms, and aesthetic criteria."); Kaplan, Decision Theory and the Factfinding Process, 20 STAN. L. Rev. 1065, 1089-91 (1968) (demonstrating the complexity of estimating probabilities of all the relevant data to determine a witness' credibility, a task that "would be unbearably complicated" if not left to a "factfinding body that could reach intuitive judgments based at least in part on its own experience"). 
dence and social science scholarship rely on this construct to describe factfinding. ${ }^{69}$

The categorical exceptions restrict the trier's use of its own general knowledge and experience to evaluate hearsay in two ways. First, the hearsay that the exceptions exclude as unreliable is classified on the basis of a far narrower range of knowledge about reliability than that available to the trier. As the distillation of experience, the trier's general knowledge is superior to the categorical generalizations drafted by the judges and legislators. This is true even if the categorical exceptions were wholly abstracted from experience. In the arena of everyday life, judicial and legislative drafters have no special expertise about reliability that justifies imposing their beliefs on triers of fact. But the categorical generalizations are not simply derived from real experience with reliability. Rather, they are the product of the necessities of proof encountered during a different historical era, value-laden with bureaucratic concerns about administering the trial process, and fashioned to serve as precedent for the general run of cases.

Second, the hearsay admitted by the categorical exceptions is usually presented with incoinplete foundation facts that limit the range of real-life knowledge and experience the trier can use for evaluation. The hearsay admitted under the categorical exceptions must still be evaluated since the exceptions, because of their broad and abstract nature, cannot correspond with any more than a low degree of probability to the conclusions they assert about reality, which is concrete and full of detail. If hearsay statements are admitted with only the limited facts necessary to conforn to the exceptions, the only generalizations that are available to the trier are tliose grounded on these limited facts.

An approach that does not impose external generalizations about reliability on the trier attempts instead to enhance the trier's functioning by increasing the quantity and quality of the foundation facts available. More foundation facts trigger the trier's use of a wider range of more specific knowledge and experience. More detailed information about the declarant allows the trier to apply general knowledge that is both closer to its level of experience in the real world and more directly pertinent to testimonial qualities.

More specific foundation facts facilitate evaluation in another way as well. Rational decisionmaking posits that one way the trier can decide about the reliability of a particular hearsay declarant is to make a rougl estiunate of the probable correlation between the general class of people who share characteristics of the declarant-for example, "people wlio are

69. R. Hastie, S. Penrod, \& N. Penningron, supra note 28 , at 18 ; W. Twining, supra note 26 , at $131-35$. 
waiting for a bus"- and the related testimonial quality of perceptionfor example, "are likely to perceive accurately whether the bus stopped at the corner stop sign." A more abstract general class-for example, the class defined by the categorical exception for present sense impression of "people who say they have just seen a bus accident"-increases the difficulty and uncertainty in estimating such a correlation. ${ }^{70}$

More specific foundation facts help reduce or avert this uncertainty by triggering a network of applicable general knowledge and experience. Intersecting generalizations may describe a narrower class of declarants that provokes estimation of more influential probabilities, whether higher or lower. ${ }^{71}$ Other generalizations pertinent to the declarant's perception-such as "people who have good eyesight" or "people who are exhausted after work"-may simply coalesce at the final application stage to tip the balance for or against an inference about the declarant's reliability.

Hearsay admitted under the categorical approach requires the presentation of only those facts pertinent to the category's terms. Because many current exceptions focus only on the circumstances affecting one testimonial quality, typically sincerity, deficiencies in foundation facts are even more likely. For example, the class of people defined by the exception for excited utterances-"people who speak excitedly about bus accidents"-may bear no relationship to the testimonial quality of accurate perception. Only fortuitously miglit the proponent present information relevant to the declarant's perception opportunity. ${ }^{72}$

Focusing learsay policy on foundation facts to enhance the trier's use of its own general knowledge and experience is consistent witl the value of operational accuracy underlying much of modern evidence law. The general policy of maximizing the admission of evidence for the trier's evaluation has fueled the reform of many common law strictures on proof, including the ascendance of logical relevancy and the liberalization of the authentication and best evidence rules. ${ }^{73}$ These reforms

70. Lempert, supra note 28 , at 1029 ("An estimation problem . . . exists when there is so little information about the relationship of certain evidence to the hypothesis in question that the implications of the evidence are unclear.").

71. For example, the class of "people who are speaking to their children while waiting for a bus" may be much less likely to perceive the bus accurately.

72. See infra note 217 and accompanying text.

73. See FED. R. Evid. 401 and 402 (logical relevance); James, Relevancy, Probability and the Law, 29 CALIF. L. REv. 689 (1941); Trautman, Logical or Legal Relevancy-A Conflict in Theory, 5 VAND. L. REV. 385 (1952).

Rule 901 has turned the issue of authenticity into a question for the trier of faet. FED. R. EvID. 901 advisory committee's note (authentication falls into category of relevance dependent on fulfillment of a condition of fact, which under rule 104(b) is a question for the trier of fact); McCoRM1CK, supra note 2, at $\$ 227$; S. SALTzBuRG \& K. REDDEN, supra note $24, \S 351$, at 1008 (contending that rule 901 should modestly be applied to modify the common law "in the light of reason and experience"); see also FED. R. Ev1D. 1001(4), 1003 (adopting a reasonable approach to 
have increased the adversaries' ability to present all relevant evidence to the trier of fact on the premise that this is "the way to find the truth."74

Imposing external generalizations about reliability on the trier of fact not only departs from this general trend, it also runs counter to the explicit policy that the trier of fact should evaluate the credibility of witnesses. Judicial and legislative beliefs about unreliable witnesses once hampered the trier's evaluation of testimonial reliability. For centuries, common law rules and statutes permitted judges to exclude whole classes of people from testifying on the grounds that they were categorically untrustworthy. ${ }^{75}$ Judges always decided the factual questions upon which individual cases of incompetency turned. ${ }^{76}$ The trier might well have found these sources of knowledge useful, but imposing the judges' belief in their lack of trustworthiness foreclosed this option. ${ }^{77}$

This legislative and judicial power over the trier's evaluation of witnesses has been reduced substantially during the past century. In many jurisdictions, the rigid categories of incompetent witnesses have been abolished. ${ }^{78}$ Comment is permitted in the federal courts, but must be

modern copying techniques); FED. R. EvID. 1004 (eliminating any ranking of "degrees" of secondary evidence).

Under rule 702, admissibility of expert and scientific knowledge is premised on it being outside the normal realm of the trier's knowledge and experience. Maintaining substantive external controls on the admission of such knowledge is a sensible precaution.

74. MCCORMICK, supra note $2, \S 184$, at 540; see also Saltzburg, $A$ Special Aspect of Relevance: Countering Negative Inferences Associated with the Absence of Evidence, 66 CALIF. L. REV. 1011, 1015 (1978) (asserting that "irrational exclusion of evidence may harm a rational decisionmaking process more than irrational admission of evidence," while acknowledging that "[a]n important judicial interest is to promote decisionmaking aceuracy by admitting only evidence that meets established standards of reliability" (footnote omitted)).

75. MCCoRMICK, supra note 2 , §§61-67; see also 2 J. WIGMORE, supra note $2, \S 488$ (a compilation of the statutes on competency for each state). Categories of incompetent witnesses included parties, other persons with interests in the litigation, convicted felons, and children or insane persons disqualified on grounds of immaturity or mental incapacity. Witnesses who could not satisfy rigorous oath-taking requirements were also excluded. MCCoRMICK, supra note $2, \S 63$, at 157 ("Belief in a Divine Being who, in this life or hereafter, will punish false swearing was a prerequisite at common law to the capacity to take the oath." (footnote omitted)).

76. MCCoRMICK, supra note $2, \S 70$, at 168 .

77. A judge could also directly influence the jury's generalizations by expressing her view of the evidence in the case, including her opinion of the credibility of witnesses. F. JAMES \& G. HAZARD, supra note $31, \S 7.14$, at 358 . Although comments do not have the force of judicial instructions, their influence is significant.

78. MCCoRMick, supra note $2, \S \S 61,71$, at $155,168-69$. Rule 601 , for example, states that every person is competent. Rule 601 also provides that state law on competency shall govern in cases where state law supplies the rule of decision. Of the former common law strictures on competency, generally only the Dead Man's Statutes remain in force in some states. McCoRMick, supra note $2, \S 65$, at 159 . The issue of incompetency, when raised, may even be a question of fact for the jury. Cf. S. SALTZBuRg \& K. REDDEN, supra note 24, at 423.

The requirements of oath-taking also have been relaxed under the Federal Rules. Only if a person cannot respond to questions or cannot acknowledge her obligation of truthfulness may the judge exclude her testimony. FED. R. EvID. 603 advisory committee's note ("The rule is designed to 
used with restraint. ${ }^{79}$ The judge generally may not refuse to submit a case to a jury or enter judgment notwithstanding the verdict based on her own evaluation of credibility. ${ }^{80}$ In short, setting normative standards of belief about testimonial reliability is thought not to be the business of government.

The legal system's preference for using the trier to evaluate the reliability of proof does not mean it is naive about the potential for inaccurate results. Despite the rules regulating the admission of relevant evidence and the instructions given to the trier to adhere to rational decisionmaking, there are well-recognized risks that decisions will be made on nonrational grounds. ${ }^{81}$ The institution of trial adjudication, with its fact outcomes shielded from any process of de novo review, developed because there is generally no independent means of verifying the historical accuracy of the trier's decisions about facts. The process itself is constitutive of the facts it purports to uncover. ${ }^{82}$ Truth, if viewed as the

afford the flexibility required in dealing with religious adults, atheists, conscientious objectors, mental defectives and children.").

79. The populist political movement in the 19th century was influential in limiting the power of the trial judge over the jury. In many states, statutes and constitutional provisions restricted judicial comment on the evidence. Sunderland, The Inefficiency of the American Jury, 13 Mich. L. REV. 302, 307-09 (1915). Federal Rule 105, as originally proposed, gave federal judges explicit authority to comment on the credibility of witnesses. See Preliminary Draft of Proposed Rules of Evidence for the United States District Courts and Magistrates, 46 F.R.D. 161, 191 (1969). This provision was not enacted, however, leaving federal judges' discretionary authority to comment undisturbed, so long as the comment does not "excite [in the jury] a prejudice which would preclude a fair and dispassionate consideration of the evidence." Quercia v. United States, 289 U.S. 466, 46972 (1933).

80. F. JAMES \& G. HAZARD, supra note 31 , $\$ 7.11$, at 341 ; see J. FR1EDENTHAL, M. KANE \& A. Miller, Civil. Procedure $\S 12.3$, at 547 (1985); E. Morgan, supra note 28, at 80 (" The judge may reject the testimony of a witness that he perceived a matter if he finds that no trier of fact could reasonably believe that the witness did perceive the matter.' This last sentence expresses a proposition of judicial notice. If no trier of fact could reasonably believe the assertion, the court judicially knows it is untrue.") (quoting UN1F. R. Ev1D. 19); Dow, Judicial Review, 88 NEB. L. REV. 835, $841-48$ (1959) (grounds for requiring belief or disbelief of a particular witness are judicial admissions, equivocation, unreasonableness, and estoppel).

With regard to motions for a new trial, see Lind v. Schenley Indus., 278 F.2d 79, 89 (3d Cir.) ("since the credibility of witnesses is peculiarly for the jury it is an invasion of the jury's province to grant a new trial merely because the evidence was sharply in conflict") (quoting 6A J. MOORE, J. Lucas \& G. Grotheer, MOORE's Federal Practice \ 59.08[5], at 59-146 to -47 (2d ed. 1948)), cert. denied, 364 U.S. 835 (1960); C. Wright \& A. Miller, Federal Practice and Procedure $\S 2806$, at 44,49 (1973).

81. MCCORMICK, supra note $2, \S 185$, at $544-45$ (some of these risks are categorized as "costs" justifying the exclusion of relevant evidence under rule 403).

In part due to the nature of the trier's background knowledge discussed supra note 68 , we do not, and probably cannot, check to see how carefully or closely the trier adheres to rational decisionmaking. The trier should not, however, engage in conscious deviations from the processsuch as speculating unnecessarily, flipping a coin to reach a conclusion, or reaching a decision unsupported by an affirmative belief.

82. One does not have to posit that a real material world does not exist to agree with this point. Trial and appellate courts defer to the factual findings of the trier on the basis of a standard even less stringent than a coherence theory of truth. The courts ask only whether the trier has reached a 
correspondence between outcomes and actual past events, cannot legitimate results. Values related to the political role of the factfinder and to the nature of the general knowledge applied are critical to legitimacy. ${ }^{83}$

\section{Increasing the Independence of the Trier of Fact}

The independence of the trier of fact from government control legitimates the outcomes of trials in a democratic state. Independence means that the trier's conclusions about reliability are nonaccountable, and that its general knowledge can be nonprecedential. The lay jury is the paradigm independent factfinder, but the values of independence attach to the trial judge in her role as factfinder as well.

The jury's decisions are nonaccountable, meaning that in its verdict, the jury does not give an account of what sources of knowledge it relied on, or how it evaluated their credibility. ${ }^{84}$ The jury does not disclose which foundation facts it used, does not explain the coherence and validity of the general knowledge it applied, and does not have to justify its conclusions as against other possible choices.

Keeping the jury nonaccountable is desirable for many reasons. It permits the decisionmaking system to function efficiently. Moreover, accounting for how inferences are made may not even be possible. ${ }^{85}$ The

conclusion which could best explain all the relevant evidence made available to it; the courts do not impose their own view of the coherent result. See supra note 31.

83. Hart \& McNaughton, supra note 30 , at 45 (adjudicative factfinding is "a last-ditch process in which something more is at stake than the truth only of the specific matter in contest. There is at stake also that confidence of the public generally in the impartiality and fairness of public settlement of disputes which is essential if the ditch is to be held and the settlements accepted peaceably."). Values that legitimate the outcomes of adjudication on grounds other than accuracy are those attached to the use of lay jurors, see J. Friedenthal, M. KANE \& A. Milier, supra note 80, $\S 11.1$, at 472-73; Mansfield, supra note 28 , at 402-06, and those values attached to the adversary system of proof, see Hart \& McNaughton, supra note 30, at 63; Professional Responsibility: Report of the Joint Conference of the American Bar Association and the Association of American Law Schools, 44 A.B.A. J. 1159, $1160-61$ (1958); Saltzburg, The Unnecessarily Expanding Role of the American Trial Judge, 64 VA. L. REv. 1, 17-19 (1978).

84. The grounds of a general verdict "are not ascertainable even on a theoretical basis." $F$. JAMES \& G. HAZARD, supra note $31, \S 7.15$, at $366 \mathrm{n} .15$. Special verdicts, or interrogatories on the issues made by the pleadings, focus attention on the questions allocated to the jury and require specific answers. Id. at 368. But, "In most cases, the variety of factual issues and the number of possible combinations of findings make it impossible even for judge and litigants to frame adequately detailed, alternative specific findings." Cooper, supra note 31, at 906 . Federal Rule of Evidence 606 (b) prohibits official inquiry into the jury's reasoning underlying its verdict.

85. The decision that hearsay is reliable may involve subjective or intuitive choices that cannot be articulated. See supra note 68 and accompanying text. Even when a consensus agrees on a certain decision, it may not agree on the reasons for that result. No rules or mediating principles exist to govern, and therefore to account for, jury decisions. The jury is not instructed that it must or should make all inferences that it deems more probable than not.

If the jury were accountable, it might have to rely on the relevant burdens of proof whenever it could not articulate a justification for its conclusions about reliability. This would increase the burden on plaintiffs and prosecutors, who would then have to produce the kinds of proof that constitute a preponderance (or eliminate all reasonable doubt) in easily describable ways. 
jury's nonaccountability also prevents judicial review of the jury's generalizations. Review of what general knowledge the jury relied on in its evaluation of proof would inevitably engender disagreement, particularly in close cases. Judges' attempts to impose their own view of experience through rigid common law rules (such as the "stop, look, and listen" rule) necessarily result in displacement of the jury's general knowledge. If the uncertainties inherent in evaluating testimonial reliability were subject to judicial second-guessing, a crucial basis for the jury's independence would disappear.

It is no more a proper function of government to set normative standards about the reliability of particular types of declarants, than it is to set such standards about the reliability of witnesses. The general knowledge and experience that a jury uses to evaluate proof is preferable because it is nonprecedential. If the jury were accountable, or if it decided more than one case, it might start aiming for consistency. Instead, to the jury, each dispute and the people it involves are unique. Jurors apply general knowledge from their daily experiences rather than generalizations that characterize and evaluate a general run of similar cases.

Nonprecedential generalizations contribute to trial adjudication's goal of individualized justice, "the just result in the light of concrete circumstances of the case." 86 In contrast, precedential bureaucratic generalizations give undue weight to government or other established interests and policies that go beyond the outcome in a particular case. The jury is unlikely to have knowledge of the wider impact of legal rules; thus, its generalizations take no account of outcomes beyond the case before it.

Nonprecedential adjudication protects individual freedom of action froin unjust coercion by the state. The function of the independent jury as a bulwark against the application of unjust laws depends on judges deferring to the jury's factfinding. ${ }^{87}$ The diverse and democratic nature of the lay jury reduces the risk of systematic bias or other prejudice.

Unaccountability of the jury can therefore be viewed as a limit on their burden, and a counterweight to the conservative structure of adjudication established by such burdens of proof.

86. Damaska, Presentation of Evidence and Factfinding Precision, 123 U. PA. L. REV. 1083, 1103-04 (1975); see also 1 T. Starkie, A Practical Treatise on the LaW of Evidence 444 (3d ed. Philadelphia 1830) ("A Juror, . . . called on to discharge his duty but seldom, posesses neither inclination or opportunity to generalize and refine; unfettered, therefore, by technicalities, he decides according to the natural weight and force of the evidence."); $c f$. Saltzburg, supra note 83, at 37 ("the judge's past experiences may well bias the inferences drawn or lead the judge to a premature conclusion").

87. The Supreme Court's articulation of the purpose of jury trial in criminal cases- "to prevent oppression by the Government," Williams v. Florida, 399 U.S. 78, 100 (1970)—applies equally to factfinding and application of law. See J. FRIEDENTHAL, M. KANE \& A. MILLER, supra note $80, \S 11.1$, at $472-73$; F. JAMES \& G. HAZARD, supra note $31, \S 7.15$, at 369; $c$. Mansfield, supra note 28, at 401-02 (suggesting considerations for drawing inferences of fact and law). 
A foundation fact approach would enlarge the independence of the jury's conclusions about reliability. Hearsay statements would not be excluded on the basis of legislative and judicial generalizations. The standards of admission would focus on the proponent's obligation to produce knowledgeable foundation witnesses. Foundation facts available for the trier's evaluation would not focus primarily on the specific circumstances that rule drafters believe to be important. Hearsay policy would also be independent of judicial and legislative concerns about the effects of admission or exclusion on the administration of substantive law. ${ }^{88}$ These issues, if they are resolved, require consideration of values beyond the scope of hearsay policy. ${ }^{89}$

It makes no difference to this analysis that judges serve as factfinders in non-jury trials. The values attached to independence from precedential judicial control are still at stake. A judge in a bench trial is expected to act as a lay factfinder, applying her own general knowledge and experience like any individual juror. The foundation fact approach frees the judge from having to apply the more rigid and precedential categorical approach when accounting for an evaluation of hearsay in making findings of fact. It thus proinotes individualized and nonprecedential factfinding by a trial judge as well as by a jury. Its standards also direct the judge's attention to the primary subject of evaluation: the facts produced by foundation witnesses. And it still permits the judge to apply any personal expertise that she inay possess.

\section{Achieving Fairness Through Trial Accèss to Proof}

Fairness between the parties legitimates the outcomes of trial adjudication in an adversary system. The proponents' fairness claim is to be allowed to perform their trial function-proving their own cases and enforcing the substantive law, with the freedom to use the widest range

88. Commentators recognize that substantive law values shape the admission of hearsay. See Bein, Substantive Influences on the Use of Exceptions to the Hearsay Rule, 23 B.C.L. REV. 855, 861 (1982) (contending that certain hearsay exceptions were created when the substantive law turned on facts that were only, or best, proved through hearsay); see also R. LEMPERT \& S. SALTZBURG, supra note 46, at $390 \& \mathrm{n} .71$ (arguing that employer accountability for the unauthorized statements of agents is not justified by the adversary system rationale used to justify other hearsay admissions); James, supra note 42 , at 798 (suggesting that freer admission of hearsay can resolve burden of proof problems where the evidence is largely controlled by parties not bearing the burden such as large corporations); Saltzburg, Standards of Proof and Preliminary Questions of Fact, 27 STAN. L. REV. 271, 303-04 (1975) (advocating a preponderance burden of proof for preliminary facts establishing that a conspiracy exists before admitting hearsay to enable prosecutors to prove the conspiracy).

89. See, e.g., Motomura, Using Judgments as Evidence, 70 MiNN. L. REv. 979, 991-1002 (1986) (discussing the value of minimizing the evidentiary burden on private plaintiffs in antitrust and employment discrimination litigation, and the value of relieving patent holders from the expense and uncertainty of continually reestablishing patent validity in patent litigation, as grounds for making prior judgments admissible evidence). 
of accessible evidence. ${ }^{90}$ The opponents' fairness claim is to have access to the proponent's sources of proof at trial. Admitting hearsay deprives opponents of access to the declarant who is the proponent's source of knowledge. This protects the declarant from public scrutiny, forestalls immediate cross-examination, and thus may generate mistakenly positive inferences about the declarant's reliability. ${ }^{91}$ The opponent bears the risk of this mistaken evaluation.

An opponent's access to the proponent's sources of proof is also a normative standard of fairness, independent of any instrumental effect on the accuracy of outcomes. Use of a hearsay declarant creates burdens for the opponent beyond any risk of mistaken reliance. Losing trial access to the sources of the proponent's proof means losing access to foundation facts that are crucial to evaluation, and for which the proponent normally incurs the greater burden of expense by having investigated, prepared, and produced the only source of proof in court. An opponent who wants to reduce the risk that the trier will rely on a declarant must bear the burden of producing a source of foundation facts, either the declarant or another witness. ${ }^{92}$ To the extent that the proponent avoids producing sources of foundation facts altogether, more risks and costs shift to the opponent.

The categorical approach to hearsay does not achieve a principled resolution of the conflict between the fairness claims of proponents and opponents. Wigmore developed a principle of necessity, along with his categorical principle of circumstantial trustworthiness, to justify the admission of hearsay and the resulting harm to the opponent. ${ }^{93}$ This principle was based on the fairness claim of the proponent: if a hearsay declarant was unavailable to be a witness, the declarant's knowledge

90. The parties exercise an entrepreneurial role in adjudication. They know about the range of disputes and the range of admissible evidence that could be presented for decision. Their choices have outcome-determinative effects. When the accuracy of factfinding is uncertain, the private sector's freedom to make these choices legitimates the outcomes of the adjudication system. This entrepreneurial role is limited, of course, by judge-imposed rules controlling the admission of proof.

91. For example, if the proponent uses a declarant whose language on its face is favorable to her version of the case, the proponent gets the benefit of the generalization that people usually use language according to its ordinary meaning. All risks of mistake, peculiarity, and ambiguity in the declarant's use of language are borne by the opponent, who cannot test the language through crossexamination as with a testifying witness. In addition, hearsay declarations foreclose at least one typical method of impeachment. A typical witness may be cross-examined about her own specific acts that show a dishonest character. The opponent cannot ask anyone about a declarant's speeific acts, however, unless the proponent offers an opinion witness pursuant to FED. R. EvID. 608(a)(2).

92. The opponent has three options. First, the opponent can try to produce the declarant as a witness, if known and available. Second, she can investigate and try to produee other witnesses to furnish the foundation facts that the proponent has ignored or tried to suppress. Finally, the opponent can try to present case-specific proof contradicting the declarant's version of the facts. If the declarant's identity is unknown, this last option is the only way of discrediting or impeaching the declarant's perception.

93. 5 J. WIGMORE, supra note 2 , $\S \S 1420-1422$, at 202-05. 
would be lost to the proponent and the trier unless admitted in hearsay form. Some hearsay statements were admitted from the very beginning of the exclusionary rule for this reason. But admitting hearsay solely to accommodate the proponent is unprincipled. No principle of fairness justifies admission of evidence simply because a proponent needs it to win. $^{94}$

Under the Federal Rules, the arguments of necessity remain unprincipled. A few of the categorical exceptions under rule 804 require that the declarant be unavailable, but they also are supposedly cloaked with circumstantial guarantees of trustworthiness. ${ }^{95}$ Moreover, expedience not even approaching necessity motivates the admission of much hearsay under rule $803 .^{96}$

The resulting increase in the proponents' freedom to use hearsay declarants is deemed fair to opponents because the declarants are deemed reliable enough to forego testing by cross-examination. But this ignores the extra burdens visited upon opponents who lose trial access to witnesses. It collapses the full meaning of fairness into merely a means to increase externally defined, reliable inputs. ${ }^{97}$ In practice, this has meant

94. A standard for admitting hearsay based on true necessity is also unadministrable. Judges would have to scrutinize all of the proponent's available proof sources, a task they are unable to perform, either alone or by relying on opponents to serve as an adversarial foil. Indeed, this would require opponents to uncover proof against themselves.

The residual exceptions require the proponent to show that the offered item of hearsay is "more probative on the point for which it is offered than any other evidence which the proponent can procure through reasonable efforts." FED. R. EvID. 803(24), 804(b)(5). Cases considering "reasonable efforts" have required live testimony from available witnesses instead of correspondence in attorneys' files, In re Fine Paper Antitrust Litig., 751 F.2d 562, 586 (3d Cir. 1984), and conversely, have also required business records themselves rather than hearsay statements describing their contents. United States v. Kim, 595 F.2d 755, 764-66 (D.C. Cir. 1979). In these cases, obvious substitute sources of proof existed even if these substitutes were less convenient for the proponent.

95. The Advisory Committee attributes a "specified quality" to the four categorical rule $804(\mathrm{~b})$ exceptions that make the admission of the hearsay statements preferable to the loss of the evidence: Exception (I) (former testimony) ("Both oath and opportunity to cross-examine were present in fact"); Exception (2) (dying declarations) ("[I]t can scarcely be doubted that powerful psychological pressures are present"); Exception (3) (declarations against interest) ("[P]ersons do not make statements which are damaging to themselves unless satisfied for good reason that they are true"); Exception (4) (statement of personal history) ("[D]eclarant is qualified if related by blood or marriage [or] . . . by virtue of intimate association with the family."). FED. R. EvID. 804(b) advisory committee's note.

96. Wigmore divided the principle of necessity into two categories: circumstances making the hearsay declarant unavailable and circumstances "such that we cannot expect . . . to get evidence of the same value from the same or other sources." $5 \mathrm{~J}$. WIGMORE, supra note $2, \S 1421$, at 253 (emphasis in original). Neither of these categories reflects true necessity, which occurs only when one side has no proof of a disputed fact other than the hearsay statement. Wigmore recognized that merely being threatened with the loss of some valuable source of evidence was "perhaps hardly a necessity, only an expediency or convenience," but he still insisted on calling necessity a principle. Id.

97. See E. MORGAN, supra note 28 , at 245. By characterizing the problem of hearsay as the risk of misleading the trier, rather than the difficulty of evaluating vel non due to lack of foundation 
that almost any broad categorical generalization about reliability can justify the opponent's loss of trial access to the proponent's source of proof. This is an especially pernicious result when the categorical generalizations actually used focus too narrowly on sincerity, ${ }^{98}$ are unsupported, and even unsound. ${ }^{99}$

The foundation fact approach addresses the opponent's access to the proponent's sources of proof in functional ternis. It imposes an obligation on the proponent to present hearsay through a foundation witness knowledgeable about the circumstances affecting the reliability of the hearsay statement. Trial access to this witness allows the opponent to test and impeach the foundation for the hearsay statement through crossexamination, to use the witness as a source of foundation facts crucial to evaluating reliability, and to do all this efficiently because the proponent bears the greater burden of expense.

This standard of admission achieves a fair balance between the conflicting claims of proponents and opponents of evidence. It is fair to the proponent because it eliminates the external judgments of categorical reliability that currently constrain proponents' choices of proof. It does not impose on proponents, or on the trier, governmental notions about who is and is not reliable. It himits proponents' freedom of choice only in order to protect the functions of the trier of fact and the opponent. The foundation fact approach is also fair to the opponent. Providing trial access to the foundation witness is a fair way to counterbalance the advantages gained by admitting hearsay. Trial access to a source of knowledge about the circumstances affecting the declarant is the most direct compensation for the opponent's loss of immediate cross-examination of the declarant.

The foundation fact approach is also fair in that it is consistent with the protection of defendants achieved by the burdens of proof in civil and criminal litigation. A trial results in coercive governmental action, effected by means of judicial judgment, that changes the status quo of private ordering. ${ }^{100}$ In civil cases, plaintiffs typically seek a judgment that will benefit themselves to the detriment of specific defendants. The judgment is a governmental act that changes the defendant's circumstances, however just the result. In criminal cases, prosecutors represent

facts, Morgan at least partially accepts the fallacy of the categorical approach: that externally imposed generalizations about declarants' reliability exhaust the opponent's fairness claim.

98. See supra note 24.

99. See supra text accompanying notes 35-39.

100. See, e.g., J. Frank, CoURTS ON TRIAL 92 (1949) (drawing an analogy between the adversary system and classical laissez-faire economic theory); F. JAMES \& G. HAZARD, supra note $31, \S 6.2$, at $281-82$ ("From the viewpoint of the litigants a civil action is a struggle over the coerced resolution of a controversy. ... litigation is not an exercise in pedagogy, a debate, or participatory democracy."); E. MORGAN, supra note 28, at 17. 
the executive branch of government in seeking judgments of guilt against specific defendants, to the benefit of the public. A guilty verdict drastically changes a defendant's status.

Limiting plaintiffs' and prosecutors' freedom to use adjudication to change the status quo limits the government's use of its coercive power against specific individuals. In crimmal trials, burdens of proof imposed on the prosecutor's case obviously assume the political dimension of protecting the individual defendant in the specific case from loss of liberty at the hands of the state. These burdens also reflect the priority given to the values of individual liberty by the social and political order. ${ }^{101}$ These values structure adjudication in civil disputes as well. Placing the burden of production and persuasion on the civil plaintiff discourages casual lawsuits and institutionalizes skepticism toward court intervention to change the private order in a particular case. ${ }^{102}$

The traditional allocation of the burdens of proof protects defendants' freedom from government intervention. It does not increase the number of accurate outcomes in most factual disputes, ${ }^{103}$ but rather

101. The justifications offered by decision theorists for the risk of nonpersuasion and the reasonable doubt standard in criminal cases support this view of the values that structure adjudication in criminal cases. See, e.g., Kaplan, supra note 68, at 1073. These theorists compare the costs or harms of triers of fact making different kinds of mistakes. In criminal cases, society considers the harm from mistakenly convicting an innocent person much greater than the harm of mistakenly acquitting a guilty person. Id. Thus, triers are instructed to resolve their doubts in favor of acquittal. Convicting the innocent is more harmful because of the priority given to values of individual liberty. This value outweighs other values, such as accuracy, truth-seeking, and communal safety.

102. The cost of an erroneous judgment in a civil case is typically measured in dollars. The two sides are assumed equally able to bear this loss, and thus equally harmed by a mistaken judgment. Thus, when the trier's doubts about the facts in a civil dispute are in equipoise-if it doubts equally both versions of the events-the trier could be left free to decide either way. Instead, society instructs the trier to find against the plaintiff under the preponderance of the evidence burden of proof. This result preserves the status quo. Thus, the system prefers mistakes that conserve the status quo to mistakes that change it. An erroneous judgment in favor of the plaintiff would impose on the defendant a government-sanctioned order to transfer dollars. Such an outcome is undesirable under a laissez-faire tradition that prefers minimal use of goverument to reorder private affairs.

Where interests other than dollars are at stake, decision theory would adjust the burden of persuasion to reflect society's value preference. $C f$. id. at 1072 (noting, however, that this assumption "becomes increasingly dubious" as society "tend[s] more and more to the view that compensation, not fault, is the primary stuff of tort law"); Lempert, supra note 28, at 1033-34 (also noting the caveat that "[t]here are many civil cases in which a factfinder might feel uncomfortable with a norm that ascribes equal regret to the two kinds of mistakes").

103. See, e.g., Saltzburg, supra note 88, at $280 \mathrm{n} .33$ (imposing "beyond a reasonable doubt" persuasion burden on prosecutors does not yield the maximum number of accurate outcomes in criminal cases). Ball suggests that the burden of proof in civil cases may lead to more accurate outcomes when general preexisting probabilities concerning the general types of events disputed in the civil case favor the defendant. Thus, if the plaintiff does not move the trier beyond equipoise, the verdict should be against the plaintiff, which should correspond to the more probable version of the events in question. Ball, The Moment of Truth: Probability Theory and Standards of Proof, 14 VAND. L. REV. 807, 818-30 (1961).

This theory is unpersuasive. Actual empirical knowledge of the preexisting probabilities 
establishes institutional skepticism toward court intervention in specific cases. This skepticism is appropriate, given the pervasive uncertainty about the accuracy of adjudicative factfinding, and it limits both private and public abuse of the adjudication system. ${ }^{104}$

A foundation fact approach is consistent with the value of fairness underlying the burdens of proof. Within an adversary system of proof, the burden of producing foundation witnesses must be placed on either the proponent or the opponent of evidence. Under the foundation fact approach, plaintiffs and prosecutors bear this burden. They must investigate, prepare, and present a foundation witness if they rely on a hearsay declarant to prove the required prima facie case. Admitting hearsay without knowledgeable foundation witnesses shifts more costs and risks to defendants ${ }^{105}$ who must then develop and present impeaching foundation facts (or rebuttal evidence). A foundation fact approach would constrain plaintiffs' and prosecutors' current ability to overwhelm the defendant with hearsay statements of declarants whose evaluation may be dependent only on the indiscriminate probabilities underlying the categorical exceptions and exemptions. ${ }^{106}$

Of course, this constraint on plaintiffs and prosecutors means that if no qualified foundation witness is produced for a particular hearsay statement, the statement will not be admitted. It necessarily follows that a prima facie case dependent on this statement cannot be submitted for decision. But this result would be consistent with the common law's rejection of prima facie cases that subject the defendant to the risk of adverse judgment on the basis of indiscriminate probabilities. ${ }^{107}$

Finally, the foundation fact approach is also consistent with an obligation of fair disclosure between the parties. Although full disclosure is not required by our adversary system, a requirement of fair disclosure, such as modern rules of discovery, actually reduces any preexisting

concerning the types of general cvents in question is essentially nonexistent. Moreover, society does not allocate civil burdens of persuasion on grounds of probabilities, but rather for reasons of fairness, convenience, and policy. See Cleary, Presuming and Pleading: An Essay on Juristic Immaturity, 12 STAN. L. REV. 5, 11 (1959).

104. Cf. F. JAMES \& G. HAZARD, supra note $31, \S 6.2$, at 284 ("The parties to litigation can exercise coercion on each other. ... The simplest example[ [is] the threat to bring a lawsuit in the first place . . . there is an element of blackmail in every lawsuit.").

105. R. LEMPERT \& S. SALTZBURG, supra note 46 , at 522-24.

106. The categorical approach may waste judicial resources, as well as be unfair to defendants, by permitting plaintiffs to use declarants who appear to be reliable, but whose reliability in the particular case cannot be evaluated. Cf. S. SALTZBURG \& K. REDDEN, supra note 24, at 841 (it wastes judicial resources to force a defendant "to rebut the possible implications of a generally reliable treatise that no expert would rely on in a particular case" (emphasis in original)).

107. See, e.g., Guenther v. Armstrong Rubber Co., 406 F.2d 1315, 1318 (3d Cir. 1969); Smith v. Rapid Transit Inc., 317 Mass. 469, 58 N.E.2d 754 (1945); see also Swift, Abolishing the Hearsay Rule, 75 CAL1F. L. REV. 495, 504-05 (1987) (discussing these cases and the commentary surrounding their rejection of high statistical probabilities). 
advantages and reflects a just society's values. ${ }^{108}$ The foundation fact approach does not impose an obligation of full disclosure because the proponent need not ask questions that reveal negative foundation facts, nor produce the witness who lias the most knowledge of the most negative facts (if such a witness exists). But the obligation to produce a knowledgeable foundation witness lessens the conflict between values of adversarial competitiveness and forthright disclosure.

\section{Calculating the Costs of the Foundation Fact Approach}

At this point, some obvious concerns about a foundation fact approach can be raised. First, it may appear that requiring foundation witnesses to admit hearsay may add to the length and complexity of trials. However, presenting hearsay to the trier under the current categorical rule already requires a type of foundation witness-either someone who overheard oral hearsay or someone to authenticate written hearsay. ${ }^{109}$ Thus, using one foundation witness, or perhaps two, to satisfy the basic foundation fact approach may not be more time consuming. Traditional judicial power to exclude cumulative and needlessly distracting evidence will still exist. ${ }^{110}$ If the learsay declarant's knowledge of events is an important factor in the case, time spent on evaluating it is justi-

108. Cf. J. RAwLS, A THEORY OF JUSTICE 12 (1971). One can evaluate proposed hearsay rules under a social contract theory. Since no one knows beforehand whether they will become a proponent or opponent of hearsay, it seeins fair to agree on a process that insures the opponent's access to sources of proof about the hearsay dcclarant. See supra note 91 and accoinpanying text. Of course, complete access runs contrary to the lack of discourse and sharing viewed by most lawyers as equivalent to the ethical imperative of zealous advocacy within an adversary systein. Hart \& McNaughton, supra note 30, at $44-45$ ("When a question has reached the point of a contested trial ... its whole context is changed. Victory, and not accoininodation, is the objective of the parties. ... [Available evidence] is culled by the parties with a view not so much to establishing the whole truth as to winning the case."). Attempts to impose ethical duties of full disclosure in negotiations between lawyers, for example, have failed. See Model RULES of Professional CoNDUCT Rule 4.1 (1983); but cf. Rubin, A Causerie on Lawyers' Ethics in Negotiation, 35 LA. L. REV. 577 (1975) (calling for a standard of honesty and good faith in negotiations).

Professor Nonet posits a inoral source for both the hearsay rule and the confrontation clause in "the general duty opponents owe each other to make their positions open to scrutiny and refutation. The principle of this duty is constitutive of reasoned discourse, and has been the inspiration of all procedure." Unpublished memorandum from Professor Philippe Nonet, School of Jurisprudence and Social Policy, University of California at Berkeley, to author (March 17, 1986).

However, to impose the full moral obligation of philosophic discourse onto trial lawyers would mean abandoning the competitive underpinnings of the adversary systein. Some may prefer this result, but it is not the prevailing legal norm. Until it is, rules of evidence will have to mediate the conflict between the values of adversarial competitiveness and the values of forthright disclosure. The foundation fact approach respects both sets of values.

109. FED. R. Evid. 901.

110. FED. R. EviD. 403. This rule can be applied to control the number of foundation witnesses regarding even an inportant hearsay statement, and to limit the introduction of cuinulative hearsay altogether. Contrary to fears of an endless parade of foundation witnesses, the jury's attention span and the judge's patience motivate trial lawyers to reduce the number of witnesses. 
fied. ${ }^{11}$ Pretrial procedures can be used to resolve disputes over the qualifications of foundation witnesses, ${ }^{112}$ and even over the foundation facts themselves, whenever possible. ${ }^{113}$

Second, framing the legal standard in terms of foundation witnesses will require trial judges to apply new standards of admission. Testing the extent of the foundation witnesses' knowledge requires individualized judgments, but is not unduly discretionary. The standard of knowledge is objective, and obvious cutoffs will be drawn by both trial and appellate courts. ${ }^{114}$ The time and effort spent in qualifying a problematic foundation witness may be no greater than is currently expended in applying the categorical terms of some hearsay exceptions. ${ }^{115}$ Nor is the judgment involved in qualifying a foundation witness an atypical judicial function. ${ }^{116}$ Administering some of the categorical exceptions currently requires evaluation of the knowledge of a foundation witness. ${ }^{117}$ Expan-

111. As Cleary has commented, "Courts exist for the purpose of trying lawsuits. If courts arc too busy to decide cases fairly and on the merits something is wrong." Cleary, Res Judicata Reexamined, 57 YALE L.J. 339, 348 (1948). Of course, administration of evidence at trial must be manageable. Hence, some commentators have argued that the hearsay rule exists to promote trial efficiency because it is a "handy tool for excising time-consuming, but usually relatively useless, testimony." Hart \& McNaughton, supra note 30, at 48. Such a justification of the hearsay rule, however, is like using a cannon to kill a fly. Moreover, other commentators have asserted that society should not consider efficiency to be an independent value in litigation because it is difficult to mcasure the impact of evidence rules on the time actually consumed by courts. See, e.g. Motumura, supra note 89 , at $1004-05$.

112. See United States v. American Tel. \& Tel. Co., 516 F. Supp. 1237, 1242-43 (D.D.C. 1981) (court order specifically created a process for pretrial resolution of disputes over hearsay).

113. Judicial notice may be applicable to some process foundation facts. See infra text accompanying notes $259-79$.

114. The trial court is not concerned with a positive showing of the declarant's reliability or credibility. See supra note 46 . The basic foundation requires a witness's knowledge of three objective sets of circumstances affecting the declarant: circumstances affecting the declarant's perception of, memory of, and making a statement about a relevant event. This standard lends itself to appellate review, in contrast to the subjective nature of what constitutes both a "bad faith" memory lapse by a witness and what constitutes an "adquate basis" for evaluating a declarant. See 4 J. WEINSTEIN \& M. BeRGER, supra note 12, ๆ 803(5)[01], at 803-160.

115. The categorical approach has frequently been criticized for being overly complicated and difficult to apply. See Morgan \& Maguire, Looking Backward and Forward at Evidence, 50 Harv. L. REV. 909, 921 (1937). The Federal Rules of Evidence represent a response to complaints about the extent, complexity, and uncertainty of the common law rules. See S. SALTzBURG \& K. REDDEN, supra note 24 , at 844 . With regard to certainty and complexity, however, the sheer number of the exceptions is still ground for complaint. See, e.g., Smith, supra note 42, at 235 ("some day this kind of creation must reach its limit, and the whole structure will simply collapse from its sheer weight"). But see MCCoRMICK, supra note 2, $\$ 253$, at 753 (the number of categorical exceptions adds to the complexity but "the actual working collection probably numbers no more than 10 or a dozen").

116. One should not confuse refusal to qualify a foundation witness with the judicial discretion to exclude hearsay "on the altogether atypical, extraordinary ground" that the judge does not believe the declarant. Chadbourn, Bentham and the Hearsay Rule-A Benthamic View of Rule 63(4)(c) of the Uniform Rules of Evidence, 75 HARv. L. REv. 932, 947 (1962).

117. See, e.g., United States v. Hathaway, 798 F.2d 902, 904-07 (6th Cir. 1986); United States v. Simmons, 773 F.2d 1455, 1457, 1460-61 (4th Cir. 1985). 
sion of this approach does not present judges or litigants with unfamiliar issues beyond their capacity to resolve.

Third, abandoning categorical reliability as the justification for admitting hearsay will affect constitutional doctrine developed under the confrontation clause. In Ohio v. Roberts, ${ }^{118}$ the Supreme Court acknowledged the underlying purpose of the clause was "to augment accuracy in the fact finding process by ensuring the defendant an effective means to test adverse evidence."119 This characterization of purpose is remarkably like the goals of operational accuracy and fairness under the foundation fact approach.

But in its second, and increasimgly dominant, reading of the confrontation clause's truth-determining purpose, the Court in Ohio v. Roberts equated "indicia of reliability" or "particularized guarantees of truthworthiness" with "the substance of the constitutional protection." ${ }^{120}$ Under this holding, the confrontation clause imposes an externalized objective reliability constraint on prosecutors. The Supreme Court then equated indicia of reliability with any firmly rooted current hearsay exception; other less well rooted but admissible hearsay must show "particularized guarantees of trustworthiness."121

Thus, under a foundation fact approach, the confrontation clause would impose a burden on the prosecution in criminal cases to produce additional facts to persuade judges that declarants' statements are reliable. The discarded categorical exceptions might serve as prototypes for reliability, or else case-by-case analysis would be required to satisfy confrontation doctrine. However, by developing the Supreme Court's reference to the operational approach to accuracy, courts could use foundation fact analysis to determine whether the trier had an adequate basis for evaluating the declarant, and whether the defendant had adequate trial access to the prosecution's proof sources.

\section{III}

\section{The Foundation Fact Approach in Practice}

The values of operational accuracy, independence, and fairness generally obligate the proponent of hearsay to satisfy the basic foundation fact standard, described in Part II, of producing a knowledgeable process foundation witness. However, adjustments in this obligation are necessary in certain recurring situations. Part III shows how the foundation fact approach can address these circumstances in terms of the three hearsay values. First, it discusses how the proponent's inability to produce a

118. 448 U.S. 56 (1980).

119. Id. at 65 .

120. Id. at 65-66.

121. Id. 
process foundation witness raises an issue about the proper balance of fairness between the parties and requires an adjustment in the basic foundation. Second, it explains that it is fair to release the proponent from the basic foundation altogether when the opponent has had prior access to the declarant. Finally, it describes efficient means of providing the basic foundation for written records that incorporate the perceptions of many declarants.

\section{A. Unavailability of a Process Foundation Witness}

Under the basic foundation fact approach discussed in Part II, the proponent of hearsay must present a foundation witness knowledgeable about the declarant's perceiving, remembering, and making a statement about a relevant event. Since the declarant herself can act as such a witness, the proponent is usually able to satisfy this obligation. But when the proponent cannot produce a process foundation witness, should hearsay statements be admitted?

Example 5. In the bus accident case, a declarant told her husband that "on my way home from work I saw a bus accident. The bus driver drove straight through the stop sign." The husband testifies about these statements and about the circumstances in which the declarant made them: for instance, he testifies that she was calm, not particularly angry or upset, and that it was the first thing she said when she came into the house.

In this Example, the proponent has produced no witness knowledgeable about the declarant's perception of the event. ${ }^{122}$ Under the basic foundation fact approach, the foundation witness must have knowledge of the declarant's location; a witness with knowledge of the general scene of the bus accident will not suffice. Without such a witness, the trier's inferences about the declarant's perception are based only on indiscriminate generalizations about how accurately people who say they saw a bus accident actually perceived it.

This defeats the purpose of imposing judicial control over the admission of hearsay. That purpose is to enhance the trier's ability to apply general knowledge and experience in evaluating the specific statement made by the specific declarant. Here, nothing is known about the declarant or her perception to distinguish her from the rest of the people who might say that they saw a bus accident. The opponent has no access to information about the declarant's perception. Under the basic foundation fact approach, the statement should be excluded. ${ }^{123}$

122. The declarant's statement would pass the test of relevance since she asserted that she saw the accident. See Miller v. Keating, 754 F.2d 507, 511 (3d Cir. 1985) (implying that the assertion of perception in the hearsay statement itself satisfies the threshold for relevance).

123. Under the Federal Rules, many categorical exceptions focusing on sincerity admit 
Thus, a problem arises for proponents of hearsay when a knowledgeable foundation witness is not available for trial due to circumstances such as death, loss of memory, or absence from the jurisdiction. ${ }^{124}$ Since the declarant is always a potential foundation witness, the declarant's unavailability must be shown. If no one else perceived the declarant when the event occurred, this is also grounds for a finding of unavailability.

The proponent of hearsay would argue that it is fair to admit the statement under these circumstances because the unavailability of the necessary foundation witness is a fortuity, not the product of the proponent's tactical choice. The proponent's claim to fairness is to have maximum freedom of choice to use evidence to prove her case. The opponent argues for exclusion since her right of access to the proponent's sources of proof is violated by admission of the statement in Example 5. However, exclusion of the statement im absolute deference to the opponent may not be the most fair resolution of competing claims if the hearsay values of accuracy and independence can still be satisfied.

Under the foundation fact approach, the proponent could produce a foundation witness knowledgeable about specific facts pertinent to the declarant's four testimomial qualities to supplement the incomplete process foundation. This identification foundation witness is someone who knows the declarant and who can identify the main facts influencing the declarant's statement. Most important is the declarant's relationship to the parties or to the case at hand. Also important are the declarant's work, domestic situation, and any special experience or training. Other relevant information includes observations of the declarant exercising her testimonial qualities and opinions of the declarant's truthfulness if it has been attacked. ${ }^{125}$ Facts and opinions about other testimonial qualities would be limited by existing evidence rules. ${ }^{126}$

statements despite lack of information about the declarant's perception. See infra notes 212, 216, 224, and accompanying text.

124. See FED. R. EVID. 804(a) (defining kinds of "unavailability" that are also appropriate for the foundation fact approach).

125. See supra notes 47, 50, 51 and FED. R. EvID. 608(a)(2) (providing that opinion evidence of truthful character of a witness "is admissible only after the character of the witness for truthfulness has been attacked by opinion or reputation evidence or otherwise").

126. Lay opinions must be based on firsthand perceptions and must be "helpful to a clear understanding of his testimony or the determination of a fact in issue." FED. R. EvID. 701. Lay witnesses are currently permitted to state opinions on the effect of alcohol on a person's behavior, Evans v. United States, 277 F.2d 354, 355-56 (D.C. Cir. 1960) and Singletary v. Secretary of Health, Educ. \& Welfare, 623 F.2d 217, 219 (2d Cir. 1980), and on specific states of mind, such as knowledge and understanding of agency regulations, United States v. Smith, 550 F.2d 277, 281 (5th Cir.), cert. denied, 434 U.S. 841 (1977). Lay opinions about the declarant's perception, memory, and use of language may be no more intangible, and thus equally helpful.

Proof of specific acts related solely to the declarant's credibility may be restricted to crossexamination of opinion witnesses. See FED. R. EvID. 608(b). Nevertheless, much probative 
Thus, the identification foundation witness, in testifying about the declarant, would not expand the range of proof that is relevant and admissible today. It would, however, permit the proponent of hearsay to introduce relevant identification information about the declarant prior to any attack on the declarant's credibility by the opponent. Federal Rule 806 now provides that "the credibility of the declarant may be attacked, and if attacked may be supported, by any evidence which would be admissible for those purposes if declarant had testified as a witness." 127 This change in the order of proof makes the presentation of declarants more like the presentation of witnesses. Witnesses commonly describe relevant identification information about themselves that supports their credibility prior to any attack from the opponent. The trial judge will test the qualifications of the identification foundation witness both in terms of the content and extensiveness of her testimony, and by reference to the current practice of qualifying character witnesses under the rules of evidence. ${ }^{128}$ The witness' knowledge must be based on personal observation of the declarant and the declarant's conduct. The trial judge will have discretion to limit the testimony of the witness to its proper scope, and to limit the number of witnesses as well. ${ }^{129}$

Facts about the declarant's identity enable the trier to make independent inferences about all of the declarant's testimonial qualities. Evaluation of the declarant's perception might be derived from observations about her eyesight, such as her use of glasses; from knowledge about her job or any special training or experience with perception she might possess; from knowledge of how her route home from work places

information about a declarant is categorized neither as an opinion of truthfulness nor as specific conduct related solely to credibility. In United States v. Abel, 469 U.S. 45, 49 (1984), for example, the Supreme Court upheld admission of extrinsic proof concerning the conduct of a witness bearing on motive and bias. Thus, information concerning perception, memory, and language use may not be subject to the ban of rule 608(b).

127. FED. R. EviD. 806. Evidence about a witness's credibility is a proper subject of crossexamination. FED. R. Evid. 611(b); see also CAL. Evid. CODE $\S 780$ (West 1966) (list of matters relevant to credibility).

128. See FED. R. Evid. 405. An opinion witness must have firsthand knowledge from observing "the defendant's behavior over a length of time," Government of Virgin Islands $v$. Petersen, 553 F.2d 324, 329 (3d Cir. 1977) (emphasis in original). Opinion witnesses may be asked their opinion directly, without an elaborate predicate. See United States v. Watson, 669 F.2d 1374, 1382-83 (11th Cir. 1982); United States v. Lollar, 606 F.2d 587, 589 (5tli Cir. 1979). This relaxation assumes, however, that the opposing side can test the foundation cross-examination and that "if the court finds the witness lacks sufficient information to have formed a reliable opinion, he can exclude relying on rules 403 and 602 ." $3 \mathrm{~J}$. WEINSTEIN \& M. BERGER, supra note 12, $\| 608[04]$, at 608-20; cf. MCCORMiCK, supra note $2, \S 11$, at 29.

129. See United States v. Watson, 669 F.2d 1374, 1382 (11th Cir. 1982) ("[w]e recognize that trial courts, in the exercise of their discretion, may limit the number of character witnesses a party may call and, absent an abuse of discretion, the district court's ruling will not be disturbed on appeal."); McCoRMiCK, supra note 2, § 191, at 569; 2 J. WEINSTEIN \& M. BERGER, supra note 12, I $405[03]$, at $405-37$ to -38 . 
her at the intersection; or from knowledge of any relevant habitual behavior. ${ }^{130}$ In Example 5, inferences based on facts would coalesce in the trier's evaluation of the declarant's statements about her perception-that she saw the bus accident on her way home from work and that she saw the driver drive through the stop sign. The identification facts do not insure that the declarant is reliable, but they enable the trier to inake inferences based on its general knowledge and experience with people who share characteristics with the declarant, rather than on less discriminate generalizations about people who speak about bus accidents.

Example 6 illustrates the adjusted foundation:

Example 6. In the bus accident case, declarant makes a statement to a police officer at the scene of the bus accident. She says, "On my way home from work this afternoon I saw a bus accident. I was waiting and watching for the bus, and I saw the bus driver drive straight through the stop sign." The police officer testifies that the declarant volunteered the statement one hour after the accident, and that the police officer told her to be accurate. The declarant is not available to testify at trial.

Although this statement contains facts about the declarant's perception of the accident, it would be excluded under the basic foundation fact approach since no witness knowledgeable about these facts can provide information for the opponent and the trier. ${ }^{131}$ Under the adjusted approach, the statement could be admitted if the proponent proves that no such witness, including the declarant herself, is available to testify, and if the proponent produces an identification witness, such as the declarant's husband, who can testify knowledgeably about the declarant's identity and relation to the case.

Production of this identification witness satisfies the values underlying the foundation fact approach. The information provided by the identification witness is relevant to the declarant's perception and sincerity in asserting that she saw the accident. This permits the trier to evaluate the declarant's entire statement and serves the values of accuracy and independence. It permits the trier to evaluate the declarant independent of

130. An opinion on the declarant's habit of waiting for a bus at a particular street corner might be admissible; an opinion that she was an attentive person probably would not be admissible as habit evidence. See FED. R. Evid. 406.

131. A statement of recent past perception like Example 6, made by an uninvolved bystander, would be admissible only under the residual exceptions today. Nevertheless, a court probably would admit a statement of this general type if it also recited facts necessary to fit within the exceptions for public records, excited utterances, ancient documents, or possibly even declarations against interest. Thus, statements of recent past perception are acceptable if made by a public official about her duties, if made in an excited tone, if made over twenty years ago, or if made so as to include some self-inculpation. These circumstances shed little light on the declarant's sincerity, and even less on her perception and memory since the only available foundation facts pertinent to these qualities depend on sincerity. Without knowledge about the declarant's identity and her general qualities, the trier is given little basis for evaluation. 
substantive judicial controls on reliability. The identification witness also provides the opponent access to a knowledgeable source of proof about the declarant. Thus, adjusting the proponent's obligation under the foundation fact approach also balances the competing fairness claims of proponents and opponents.

The limits of this adjusted foundation require that no foundation witness knowledgeable about either the declarant's perceiving, or remembering, or making the statement (including the declarant) be available, and that the missing facts are asserted in the declarant's own hearsay statement. Both requirements are imposed to serve hearsay values.

Requiring unavailability serves the basic commitment to fairness for the opponent. Even though the values of accuracy and independence are satisfied by admitting the statement in Example 6, assuming that the husband testifies as an identification witness, the statement should not be admitted when the proponent simply chooses not to produce either the declarant or another available process witness. Fairness to the proponent motivates admitting some hearsay; the proponent's reciprocal obligation, however, is to produce a process foundation witness knowledgeable about facts relevant to the specific hearsay statement in order to satisfy most effectively the values of accuracy, independence, and fairness to the opponent. Only if such a witness is unavailable does admission under the adjusted foundation achieve a principled balance of fairness between the parties.

The limit requiring that the declarant assert some basic process facts is illustrated in Example 7:

Example 7. In the bus accident case, the declarant's husband finds a
piece of paper in their home, written by declarant, which states, "At the
corner of Main and First I saw a bus driver drive through the stop sign
and cause an accident." The statement contains no facts about the cir-
cumstances surrounding the declarant's perceiving, remembering, or
making the statement about the accident, and none is available from any
other source, including the unavailable declarant herself.

This statement is relevant, assuming that a bus accident took place at the corner of Main and First, and that there is a dispute about whether or not the bus driver stopped at the stop sign. However, the statement should be excluded based on hearsay policy even if the declarant's husband testifies as an identification witness. Requiring the assertion of some specific facts about the circumstances of perceiving the accident, remembering it, and making a statement about it as a limit on admission is based explicitly on the foundation fact approach's goal of enhancing the trier's ability to apply its own general knowledge and experience in evaluating the declarant. In Example 7, no information links the general evaluation of the declarant, which the trier draws from the identification 
witness, to the particular statement. Without specific facts to generate inferences, this linkage is fraught with risks of speculation and other improper bases for decision. ${ }^{132}$

The adjusted foundation principle can be stated as follows: When $a$ basic process foundation witness for a hearsay statement cannot be produced due to unavailability, specific circumstances affecting the declarant's processes of perception, memory, and making the statement can be asserted in the declarant's own statement, provided the proponent also produces an identification foundation witness.

\section{B. The Opponent's Prior Access to the Declarant}

Under some circumstances, it becomes unfair to burden the proponent of hearsay with the obligation of presenting a knowledgeable foundation witness. These circumstances can be identified by determining whether the policies that make it fair to burden the proponent in the first place-namely, in order to conform to the fairness values underlying the burdens of proof, to diminish tactical advantage taking, and to define a normative standard for the fair way to run adversarial adjudicationhave been satisfied. ${ }^{133}$

This section discusses one such set of circumstances. It describes three types of recurrent situations in which the opponent has prior access to the declarant; it determines that these three types of prior access have satisfied the fairness pohcies underlying the basic foundation fact approach. These three situations give rise to a general principle of prior access, which may be stated tlus: The proponent is not obligated to present the declarant's statement through a knowledgeable foundation witness if the opponent has had access to the declarant prior to trial. The discussion then shows how the values of operational accuracy and independence are also satisfied in these situations.

First, in some circumstances both the proponent and the opponent have had comparable pre-trial access to the declarant as a source of proof.

Example 8. In the bus accident case, a woman who witnessed the accident gives deposition testimony prior to trial. In her deposition, she describes the accident, where she was standing at the time, and how carefully she was watching, and states that she is not acquainted with any of

132. The trier can only guess at the declarant's motivation for writing the statement. No facts indicate the amount of time elapsed between the declarant's alleged perception and recollection. Thus, the trier's evaluation of the declarant's sincerity and memory is not within the model of rational decisionmaking. It is based on indiscriminate generalizations about the declarant's sincerity, perception, and memory. The statement would not be admissible under the Federal Rules either, unless the judge made an individualized decision under a residual exception.

133. See supra text accompanying notes $90-108$. 
the parties. During cross-examination at the deposition, the opponent extracted some of these foundation facts from the woman.

If the woman's deposition statements are offered at trial, she becomes a hearsay declarant. The proponent and the opponent have had equal access to the foundation facts known to the declarant, and the access is quite similar to the access provided were she a witness at trial. At the deposition, the opponent had the opportunity to question the declarant under oath and on the record about the circumstances affecting her perception, memory, and making of her statements, and about her identity and general testimonial qualities. Since one party has borne the burden and cost of producing the declarant at a deposition, and thus provided trial-type access, both parties should be free from duplicating the burden and cost at trial. The fairness values underlying the burdens of proof have already been satisfied. The proponent cannot gain unfair tactical advantage from using this declarant, since the opponent can present all the foundation facts that were uncovered during the deposition. Thus, this type of comparable prior access satisfies the opponent's fairness clain. ${ }^{134}$

Second, in some circumstances the opponent has had control over the declarant's process of perceiving, remembering, and niaking a statement, and thus has had independent prior access to the foundation facts relevant to the statement.

Example 9. In the bus accident case, the bus driver confesses to a stranger that she failed to stop at the stop sign. This hearsay statement is offered by the accident victim against the defendant bus driver through the stranger, who does not know about any foundation facts relevant to perception or memory.

In Example 9, the opponent is the declarant. She controlled her own process of perceiving, remembering, and making the statement about the accident. Thus, she has had independent and superior access to whatever foundation facts exist. It would unnecessarily burden the proponent to require her to produce a knowledgeable foundation witness. The opponent does not need to be given trial access to herself. Indeed, it might even be unfair to require the proponent to produce the opponent, as part of the proponent's case-in-chief, in order to use the opponent's

134. Under the foundation fact approach, the crucial issue is whether the proponent and the opponent had equal prior access to the declarant's foundation facts and whether their access was similar to access at trial. See infra notes $252-57$ and accompanying text.

Rule 804 (b)(1) limits admission of former testimony to instances where the declarant is unavailable. This undoubtedly excludes hearsay that the trier can evaluate. Requiring unavailability imposes a preference for live testimony over prior testimony for reasons extrinsic to hearsay policy. It certainly deters widespread substitution of deposition and pretrial hearing testimony, both types of hearsay that are commonly generated and readily available. It may reflect a value of face-to-face confrontation in criminal cases under the confrontation clause. FED. R. CIV. P. 32(a)(3) also restricts the use of depositions in civil cases to instances of witness unavailability. 
confession. Allowing the proponent to use the opponent's own expressions of belief as a source of proof, without having to call the opponent as a witness at trial, is not an unfair tactical advantage. The opponent's independent prior access to the circumstances affecting her own out-ofcourt statement satisfies her fairness claim. ${ }^{135}$

Fimally, it is not fair to burden the proponent with the obligation of producing a knowledgeable foundation witness when the opponent's prior access to the declarant has made the declarant unavailable as a source of proof. For example, the opponent may have made the declarant or other foundation witnesses unavailable to the proponent by threats or even violent means. Such unfair behavior violates the normative standard of fair adversarial adjudication and nullifies the opponent's claim to have fair access at trial. ${ }^{136}$

In these Examples, the value of accuracy is also served even though the proponent presents the trier of fact with only those foundation facts contained in the hearsay statement. The opponent is always free to present foundation witnesses (including the declarant) to impeach the hearsay statement, thus increasing the information available to the trier. The opponent's failure to impeach the statement, coupled with the opponent's equal, superior, or hostile prior access to the declarant, generates positive inferences about the rehability of the declarant's statement. The trier of fact may infer that the opponent either believed the declarant's statement or was unable to produce any foundation facts to impeach it. ${ }^{137}$ These inferences not only enable the trier to evaluate the declarant's statement, but serve the value of accuracy as well. The value of independence is unaffected since the primciple of prior access does not permit external judicial generalizations about reliability to be imposed on the trier of fact.

135. See infra notes $\mathbf{2 3 6 - 4 8}$ and accompanying text (discussing whether control over statements made by authorized and unauthorized agents provides the opponent with similar prior access to foundation facts).

136. The proponent's tampering with sources of proof are cognizable under doctrines of spoliation and waiver. See J. Weinstein, J. MANSField, N. Abrams \& M. Berger, Evidence, CASES AND MATERials 35 (7th ed. 1982); see, e.g., FED. R. Ev1d. 804(a) (refuses to accord the status of unavailability to a declarant if caused by wrongdoing of the proponent); CAL. EvID. CODE $\S 1350$ (West Supp. 1987) (developing the concept of unfair prior access to the declarant to justify the admission of some hearsay); see also United States v. Thevis, 665 F.2d 616 (5th Cir.), cert. denied, 459 U.S. 825 (1982); United States v. Howard, 228 F. Supp. 939 (D. Neb. 1964); MCCORMICK, supra note $2, \S 273$ (legal effect of spoliation).

137. The trier is aware of the following: the opponent's refusal or failure to effectively crossexamine the declarant in Example 8; the opponent's failure to explain her own statement in Example 9; and the opponent's conduct in making or keeping a declarant or foundation witness unavailable. Drawing inferences about the reliability of the declarant's statement in such situations is analogous to the body of case law which allows an opponent to invoke an adverse inference from a party's failure to call witnesses or produce evidence. McCoRMicK, supra note $2, \S 272$. 


\section{Statements Made by Multiple Declarants}

Many hearsay statements are generated by multiple declarants. ${ }^{138}$ These statements are often offered as documentary records that incorporate the perceptions of multiple original perceiving declarants as transcribed or evaluated by a reporting declarant. Some records of eventssuch as vital statistics, market reports, and marriage and birth certificates-are generated through routine compilation and recording that is open to public scrutiny and is usually not subject to reasonable dispute.

Example 10. In the bus accident case, the husband presents a certified copy of a marriage certificate to prove the date of his marriage to one of the victims.

In such cases, the judge can take judicial notice of the basic process foundation facts, rather than require the proponent to present these facts to the trier through a foundation witness. These process facts describe how the original perceiving declarants communicate information concerning the date of marriage to the official reporting declarants, and how the reporting declarants record information and issue marriage certificates. Judicial notice of these facts serves the value of accuracy. The judge informs the trier about the noticed foundation facts and instructs the trier to use them to evaluate the reliability of the statements. ${ }^{139}$ The trier obtains the facts necessary to its evaluation function ${ }^{140}$ in an effi-

138. The kinds of hearsay admitted under FED. R. EvID. 803(6)-(23) typically involve multiple declarants.

139. FED. R. Evid. 201(g) (in a civil case, the court instructs the jury that it must accept judicially noticed facts, while in a criminal case, the court instructs the jury that it may accept judicially noticed facts). The rationale for this rule in criminal cases is expressed in MCCormick, supra note 2, § 323, at 932-33 ("a criminal trial jury may be a body which ought to be free to return a result which as an exercise in logic flies in the face of reason").

140. Admission of a hearsay document through judicial notice of its foundation does not necessarily insure the reliability of the statements contained therein. While judicial notice of the foundation facts underlying a document's production often suggests that the document's contents are also trustworthy, these two issues are nevertheless distinct.

Some cases take judicial notice of the facts surrounding a document's production. See, e.g., Harcon Barge Co. v. D \& G Boat Rentals, Inc., 746 F.2d 278, 282 n.1 (5th Cir.) (judicial notice of district court clerks' uniform practice of entering dates of filing and entries of judgments or orders), reh'g on other grounds, 784 F.2d 665 (1984) (en banc), cert. denied sub. nom. Southern Pac. Transp. Co. v. Harcon Barge Co., 107 S. Ct. 398 (1986); United States v. Posner, 405 F. Supp. 934, 936-37 (D. Md. 1975) (judicial notice of a term referring to the date on which assessment officer signed records).

In other cases, courts take judicial notice of the contents of the records as well as the process foundation facts. See, e.g., Massachusetts v. Westcott, 431 U.S. 322, $323 \mathrm{n} .2$ (1977) (judicial notice of records of Merchant Vessel Documentation Division of the Coast Guard as source of fact that respondent held a federal fishing license); Bethel Conservative Mennonite Church v. Conmmissioner, 746 F.2d 388, 392 (7th Cir. 1984) (judicial notice of "church documents which detail the history of various mutual aid practices"); Newman v. Village of Hinsdale, 592 F. Supp. 1307, 1309 n.8 (N.D. III. 1984) (judicial notice of records of National Oceanic and Atmospheric Administration to ascertain amount of snowfall on day in question), aff'd without opinion, 767 F.2d 925 (7th Cir. 
cient manner. ${ }^{141}$ In addition, the value of independence is not compromised because the judge does not impose judicial generalizations onto the trier. The standard for judicial notice requires verifiable certainty: facts "capable of accurate and ready determination by resort to sources whose accuracy cannot reasonably be questioned." 142 Finally, judicial noticetaking also serves the value of fairness. If there is a genuine dispute about the process of producing the document or any special surrounding circumstances, the opponent may require the proponent to produce a knowledgeable witness during the process of judicial notice-taking. ${ }^{143}$

Many other records of events are produced by a process of perception or reporting that is not routine, may not be public, and usually is not the subject of judicial notice. The proponent can be released from producing a foundation witness who is knowledgeable about foundation facts relevant to the original perceiving declarants if these declarants have been evaluated by a reporting declarant with expertise. Hearsay policy is satisfied so long as the reporting declarant's expertise is presented to the trier by a knowledgeable foundation witness.

Example 11. In the bus accident case, a traffic safety official investigates the accident and writes a report making factual findings about the accident. The official is the reporting declarant who investigated the scene of the accident and the damaged vehicles, and who interviewed some original perceiving declarants. Based on these sources of information, she concludes that the bus driver stopped at the stop sign before entering the intersection. At trial, the proponent presents the report through a foun-

1985); United States v. 97.19 Acres, 511 F. Supp. 565, 568 (D. Md. 1981) (judicial notice of Federal

Reserve Bulletin as source for average rates of return on United States debt obligations).

141. In addition to serving the value of accuracy, judicial notice of process foundation facts promotes efficiency by eliminating the need to spend time proving the "noticed" facts at trial. See G. LlLLY, supra note 23, at 13 ("judicial notice ... expediates the trial . . . [and] . . serves as a method by which the judge can prevent highly improbable findings of fact by the jury"); see also MCCoRMrCK, supra note $2, \S 232$, at 931 (" "failure to exercise [judicial notice] tends . . to smother trials with technicality and monstrously lengthens them out" " (quoting J. THAYER, PRELIMINARY Treatise on EVIdENCE 309 (1898)); S. SALTZBurg \& K. RedDEN, supra note 24, at 60 ("a means of conserving scarce judicial resources").

142. FED. R. EvID. 201(b)(2). Rule 201 applies to adjudicative rather than legislative facts. See FED. R. Evid. 201(a) advisory committee's note (quoting $2 \mathrm{~K}$. DAVIS, AdMINISTRATIVE LAw TREATISE 353 (1958)). Foundation facts that establish the process surrounding the generation of certain documentary records are adjudicative facts - facts to which the law is applied in the process of adjudicating the particular controversy before the court.

143. Discretion in the judicial notice process contemplates an opportunity for the opponent to prevent the court from taking judicial notice. See Oneida Indian Nation v. New York, 691 F.2d 1070, 1086 (2d Cir. 1982), rev'd on other grounds after remand, 732 F.2d 261 (2d Cir. 1984); FED. R. Evid. 201(c)-(e) advisory committee's note. This may require a hearing at which both parties submit and dispute evidence concerning the facts under consideration. Oneida Indian Nation, 691 F.2d at 1086. The opportunity to be heard could be part of a pretrial process of resolving preliminary evidence issues. See also Westcott, 431 U.S. at 323 n.2; Harcon Barge Co., 746 F.2d at 282 n.1; MCCORMick, supra note 2, § 333, at 934-36. 
dation witness (perhaps the official herself) who knows the process of investigation undertaken by the reporting declarant.

In this Example, the foundation witness can testify about the traffic official's perception, memory, and process of recording. But the foundation witness may not be knowledgeable about the original declarants who perceived the accident. As a result, the trier will lack relevant foundation facts to evaluate the reliability of the original perceptions, and the opponent will have no source of proof to cross-examine. If the traffic official evaluates the original declarants' reliability, the official's general knowledge and experience displace the knowledge and experience of the trier of fact.

Displacement undermines the values of operational accuracy and independence unless the traffic official, or any reporting declarant, has expertise. Current evidence law recognizes that expert knowledge and opinion promotes operational accuracy. ${ }^{144}$ Investigating experience and special knowledge in the subject matter of the investigation qualify a reportimg declarant to make findings about the cause of the bus accident. ${ }^{145}$ If the reporting declarant has no expertise, her testimony should not be admitted.

Example 12. In the bus accident case, one of the injured passengers sues the city for failing to install a traffic light at the intersection. The plaintiff presents a witness who reports that she has heard around the neighborhood that the intersection is a hazardous crossing because many vehicles fail to stop at the stop sign. To prove that many vehicles run the stop sign, the proponent offers the out-of-court statements about the intersection.

In this Example, the testifying witness can describe the neighbors,

144. FED. R. EVID. 702 (defining experts as possessing special "knowledge, skill, experience, training, or education" that will assist the trier of fact); FED. R. EvID. 702 advisory committee's note ("An intelligent evaluation of facts is often difficult or impossible without the application of some scientific, technical, or other specialized knowledge."). The admission of expert testimony is premised on the requirement that only evidence helpful to the trier of fact will be admitted. See FED. R. Ev1D. 702; see also MCCORMICK, supra note $2, \S 17$, at $44-45$ (criticizing the effect of partisanship on expert knowledge presented through the adversary system and advocating wider use of written reports from panels of experts and of information developed in administrative commissions); S. SAltzBURG \& K. REDDEN, supra note 24, at 631 (interpreting rule 702 as permitting use of an expert witness "if his specialized knowledge is helpful in deciding a case correctly.").

145. FED. R. EvID. 703 (the bases of the expert's opinion may be inadmissable hearsay if "of a type reasonably relied upon by experts in the particular field"). Rule 803(8)(C) admits reports of evaluative findings made by public officials and contemplates the investigator's use of hearsay sources as well as her own observations and research. See Baker v. Elcona Homes Corp., 588 F.2d 551, 556-57 (6th Cir. 1978), cert. denied, 441 U.S. 933 (1979). There is authority to exclude investigative reports based solely on statements made by nonexpert, perceiving declarants. See Dallas and Mavis Forwarding Co. v. Stegall, 659 F.2d 721 (6th Cir. 1981). But see cases cited infra notes 261-62 (indicating the wide variety of investigative experiences that have qualified as hearsay exceptions). 
who act as reporting declarants in perceiving and remembering talk about the intersection. The witness does not, however, know the identity of the original perceiving declarants or what circumstances affected their perception or sincerity. The trier could rely on the neighbors' evaluation of the original perceiving declarants, but the neighborhood's generalizations about reliability would then displace the trier's own knowledge and experience. If the neighbors, as reporting declarants, have no special expertise in investigating and evaluating unattributed stateinents about intersections, displaceinent should not be permitted under the foundation fact approach. ${ }^{146}$

Finally, when the trier relies on expertise, tlie proponent must produce a foundation witness knowledgeable about tlie expert's process of perceiving, remembering, and reporting the investigative findings. In Exainple 11, if no foundation witness knowledgeable about the investigation testified, only the facts stated in the report would be available. This harms the values of operational accuracy and fairness. It circuinscribes the foundation facts the trier can use to evaluate the reliability of the investigation and the expertise of the reporting declarant, and it deprives the opponent of trial access to any source of proof. ${ }^{147}$

\section{Predicting the Future of the Foundation Fact Approach}

How these adjustments to the basic foundation fact approach will evolve in practice cannot be predicted with certainty. Part III lias dealt with the tensions $\mathrm{m}$ the adininistration of hearsay that are obvious today. As with all common law doctrine, future cases will present new issues.

The point of analyzing hearsay in terms of the functional problems it presents has been to develop an approach that will address tliese problems coherently. The hearsay values of operational accuracy, independence, and fairness define a theory for hearsay policy and provide a conceptual frainework for making furtler adjustments to the basic foundation. Again, as with all common law doctrine, analysis and application of these underlying values inay generate debate and disagreement. The basic standard for admission and the tliree principle adjustments will be subjected to careful scrutiny; notling as value-laden as a systein for admitting and excluding hearsay can be structured perfectly in isolation. Should wholesale abandonment of the current categorical approach to

146. See infra notes $280-86$ and accompanying text for discussion of Federal Rules $803(19)$, (20), and (21), which admit reputation evidence regarding family history, property boundaries, general history, and personal character without necessarily requiring expertise.

147. Cf. United States v. Williams, 424 F.2d 344 (5th Cir. 1970) (holding that crossexamination of an expert witness satisfies confrontation clause requirements even when the expert's opinion is based on hearsay not admitted at trial), aff'd en banc, 447 F.2d 1285, 1290 (1971), cert. denied, 405 U.S. 954 (1972). See cases cited infra note 261, admitting investigative findings under the categorical approach in the absence of a knowledgeable foundation witness. 
hearsay appear too risky and radical, the foundation fact approach can still have an impact on hearsay policy, as Part IV demonstrates.

\section{IV}

\section{The Foundation Fact Approach Applied to the CurRent Hearsay Rule}

The current categorical hearsay rule could not be justified without its clain of increasing the accuracy of factfinding. Even though the categorical exceptions have been criticized by many coinmentators, ${ }^{148}$ the current rule either is accepted as working well enough, or is tolerated for lack of a viable alternative. ${ }^{149}$ This Article has criticized the current categorical approach on new grounds-that it diminishes the trier's ability to evaluate hearsay accurately, reduces the independence of the trier, and shifts the balance of fairness against the opponent. To further substantiate this criticism, Part IV compares the current categorical exceptions and exemptions of the Federal Rules of Evidence to the foundation fact approach. ${ }^{150}$

This comparison also reveals that the foundation fact approach can apply within the categorical structure of the Federal Rules. This is of practical importance, since it is unlikely that the categorical approach will soon be discarded. Popular belief in the validity of at least some of the categorical exceptions may be too deeply entrenched in American jurisprudence to permit complete abandonment of the current approach. Moreover, the categorical structure is popular because it controls judicial discretion to adınit or exclude individual items of hearsay, ${ }^{151}$ and provides predictability for the adversaries in planning their cases. ${ }^{152}$ This Part thus suggests incorporating foundation fact requirements into current exceptions wherever possible, in order to advance hearsay values without wholly displacing the current rule.

\section{A. The Definition of Hearsay}

A definition of hearsay determines whether or not a declarant's statement will be subjected to the hearsay rule. It thus reflects underly-

148. See Weinstein, supra note 6 , at 344-46 (comprehensive list of critics of the categorical approach).

149. Efforts to substantially revise the categorical approach into a rule of discretion have failed. See supra notes 19-20 and accompanying text.

150. All of the exceptions and exemptions in the Federal Rules are at least mentioned in this comparison. The textual discussion focuses on the major categories, while the less frequently used categories are treated in the footnotes. In addition, where state evidence rules are parallel to the Federal Rules, some illustrations are drawn from state cases.

151. Kaplan, Mason Ladd and Interesting Cases, 66 IowA L. Rev. 931, 934-36 (1981).

152. Id; see also R. LEMPERT \& S. SALTZBURG, supra note 46, at 523; McCormick, supra note $2, \S 253$, at 753 . 
ing hearsay policy. The Federal Rules' definition of hearsay illustrates the Rules' policy-to admit declarants' statements falling within broad categorical generalizations that the Advisory Committee believed or assumed to be true about declarants' reliability, particularly sincerity. Analysis reveals that this policy is unsound.

The definition adopted in rule 801 limits hearsay to those statements "offered in evidence to prove the truth of the matter asserted." 153 Under this formal definition, if a statement is not offered for the truth of the matter it asserts, it is admitted as nonhearsay, without regard to the requirements of the hearsay exceptions and exemptions. Two traditional types of statements qualify as nonhearsay under this definition: statements offered to prove an effect on the listener and statements offered to prove that legal effects ought to be imposed on the declarant. ${ }^{154}$

In addition, the definition admits three types of behavior, the proper classification of which has troubled scholars and judges for years. ${ }^{155}$ These troublesome categories are: (1) nonverbal conduct of the declarant not intended as an assertion; (2) nonassertive utterances of a declarant; and (3) non-truth-of-the-matter assertions that do not directly state the proposition of disputed fact they are offered to prove. These categories raise problems for hearsay policy when the declarant's behavior is interpreted as a so-called "implied assertion" of the declarant's belief about the disputed facts.

To illustrate the problem, a declarant's statement that "the bus driver drove straight through the stop sign" would be hearsay if offered to prove the truth of the matter it asserts-that the driver did not stop at the stop sign. However, a declarant punching the bus driver in the nose

153. The definition in rule 801 begins as follows:

(a) Statement - A "statement" is (1) an oral or written assertion or (2) nonverbal conduct of a person, if it is intended by him as an assertion.

(b) Declarant - A "declarant" is a person who makes a statement.

(c) Hearsay - "Hearsay" is a statement, other than one made by the declarant while testifying at the trial or hearing, offered in evidence to prove the truth of the matter asserted.

FED. R. EvID. 801.

154. Examples of statements affecting a listener are words providing notice, warning, or grounds for belief. Examples of statements imposing legal effects on the declarant are words of criminal conduct or words of contract. These statements can be exempt from the foundation fact approach because the trier does not need to evaluate the declarant's four testimonial qualities. In $\mathrm{S}$. SAltzburg \& K. ReDden, supra note 24, at 743-47, non-hearsay is classified as "directions, instructions, orders, recommendations;" "false statements;" "knowledge and notice;" "statements relied upon;" and "verbal acts." All but "false statements" fall into the two traditional categories described above. In contrast, falsehoods involve all four testimonial qualities. Park, McCormick on Evidence and the Concept of Hearsay: A Critical Analysis Followed by Suggestions to Law Teachers, 65 MinN. L. REv. 423, 444 n.65 (1981).

155. See Maguire, The Hearsay System: Around and Through thc Thicket, 14 VAND. L. REV. 741 (1961); Wellborn, The Definition of Hearsay in The Federal Rules of Evidence, 61 TEX. L. REV. 49, 58-64 (1982) (history and content of the debate over so-called "implied assertions"). 
immediately after the accident, which might be nonverbal conduct expressing the very same behef, would be admitted as nonhearsay under the Federal Rules unless the opponent persuaded the trial judge that the punch was intended as an assertion of belief. ${ }^{156} \mathrm{~A}$ verbal expression by the declarant such as "Shoot that bus driver" would be classified as a nonassertive utterance, while the statement that "the bus driver ought to be shot" would be classified as a non-truth-of-the-matter assertion. These two types of verbal expression, best described as "indirect speech" because their content is not a direct statement of the declarant's belief, would be admitted as nonhearsay according to the Advisory Committee's note to rule $801 .^{157}$

However, indirect speech should be included within the definition of hearsay when it is relevant only to prove the declarant's beliefs about the dispute. ${ }^{158}$ For example, the non-truth-of-the-matter assertion that "the bus driver ought to be shot" is relevant to the dispute only if the trier infers that the declarant believes the bus driver drove the bus badly. Inferences about the declarant's perception and memory of the accident, and sincerity and language use when speaking, are necessary to evaluate the declarant's behef. The trier needs foundation facts to make these inferences.

The formal "truth of the matter asserted" definition should not apply to the two types of indirect speech. ${ }^{159}$ The policy justifications stated in the Advisory Committee's note are unsound. First, the Advisory Committee assumes that indirect speech is reliable because, like nonverbal conduct, fabrication is unlikely due to "the absence of an intent to assert." 160 This assumption is not supported with empirical data

156. FED. R. Ev1D. 801(a) advisory committee's note.

157. "[N]onassertive verbal conduct and verbal conduct which is assertive but offered as a basis for inferring something other than the matter asserted [arel also excluded from the definition of hearsay by the language of subdivision (c)." Id. Several courts have already held that rule 801 was intended to define hearsay only as that speech which literally matches a disputed proposition of fact. For examples of nonmatching assertions, see United States v. Day, 591 F.2d 861, 883 (D.C. Cir. 1978); United States v. Zenni, 492 F. Supp. 464, 469 (E.D. Ky. 1980); Wellborn, supra note 155, at 83-91 (discussion of cases); $c f$. United States v. Groce, 682 F.2d 1359, 1364 (11th Cir. 1982) (marks on chart were not hearsay because not intended as assertion of intent to return to the United States).

158. See M. GRAHAM, supra note 55, at 701; Seidelson, Implied Assertions and Federal Rule of Evidence 801: A Quandary for Federal Courts, 24 DuQ. L. Rev. 741, 775 (1986); Wellborn, supra note 155 , at 92-93. There is currently disagreement whether a trial judge has any power under rule 801 to exclude indirect speech as hearsay. The debate focuses on what the rule means by "assertion," see, e.g., MCCORMICK, supra note 2, § 246, at 729-30, and on the meaning of "intent," see, e.g. Wellborn, supra note 155 , at 73-81.

159. Some commentators suggest that the declarant's intent to communicate and the "truth-ofthe-matter-asserted" test adequately categorize nonverbal conduct offered to prove knowledge and belief. See, e.g., Park, supra note 154, at 453; Wellborn, supra note 155, at 67.

160. FED. R. EvID. 801(a) advisory committee's note. The Advisory Committee clearly assumed that people engaging in nonverbal conduct usually have no intent to fabricate. "The situations giving rise to the nonverbal conduct are such as virtually to eliminate questions of 
and does not even acknowledge the empirical dimension of the issue.

Second, the Committee's conclusion about the sincerity of declarants does not withstand scrutimy. The class of supposedly reliable declarants it includes is staggeringly broad: people who do not make direct statements of their knowledge of specific facts, but who speak as if they had such knowledge. The inference that such people are sincere because they probably have no deliberate intent to misrepresent their knowledge is suspect. Moreover, other kinds of insincerity, such as emotional exaggeration, may still affect declarants. The trier is thus left with little information to evaluate sincerity effectively. The sole descriptive factspeaking indirectly about knowledge-does not identify any salient circumstances.

Finally, indirect speech is not pertinent to the declarant's remaiming three testimonial qualities-perception, memory, and language use. The Advisory Committee's note concludes that perception and memory risks are "minimal" in cases where there is no mental opportunity to fabricate. ${ }^{161}$ It is unclear whether the Advisory Committee is making an empirical assertion or a value judgment. If it is an empirical assertion, it suggests that human perception and memory are actually enhanced in the circumstances surrounding indirect speech. The note, however, provides no basis for this assumption. Recent research shows that eyewitnesses commonly make perception and memory errors. ${ }^{162}$ There is no reason to think these errors are less frequent, or less significant, when declarants make nonassertive utterances or non-truth-of-the-matter asserted statements.

Alternatively, if the meaning of the note is that the other testimonial risks are diminished not in degree, but in sigmificance compared to sincerity, this is a value judgment underlying the entire categorical hearsay policy. The Advisory Committee's treatment of insincerity as the most prevalent hearsay risk, or the one most detrimental to factfinding, is the product of tradition, not of empirical study. ${ }^{163}$ Although the drama of courtroom events focuses on simcerity, foundation facts generated by the trier's observation and the opponent's questioning of the witness at trial

sincerity." Id. Intent to communicate may be a factually administrable standard to apply in testing the sincerity of a declarant's conduct, but it is virtually impossible to apply to indirect speech, which is intrinsically communicative. Every act of speech is accompanied by an awareness that one is speaking and of the communicative potential of the speech. Testimonial awareness is an important element of most definitions of "intent," as Wellborn has noted. Wellborn, supra note 155, at 78. The Advisory Committee ignores this difference between conduct and speech.

161. Fed. R. Evid. 801(a) advisory committee's note.

162. See, e.g., E. Arnolds, W. Carroll, M. Lew1s, \& M. Seng, Eyewitness Testimony: STRATEGIES AND TACTICS 80-92 (1984); P. WALL, EYE-WITNESS IDENTIFICATION IN CRIMINAL CASES 5-25 (1965).

163. See Stewart, supra note 36 , at 8-9. Some commentators sharply dispute the current validity of this tradition. See, e.g., James, supra note 42, at 792. 
may be more helpful in evaluating perception and memory. ${ }^{164}$

Admitting declarants' speech as nonhearsay based solely on unsupported and overbroad generalizations about sincerity undermines the importance of the other testimonial qualities and is unsound hearsay policy. Sound hearsay policy requires revision of the Federal Rules' definition into a more functional approach to the problems that hearsay presents for the trier of fact. ${ }^{165}$

\section{B. Foundation Witnesses Required Under the Current Rule}

Under the Federal Rules, the terms of some categorical hearsay exceptions and exemptions already require the proponent to produce a foundation witness. This eclectic group includes certain prior statements made by a declarant who testifies, business records, and learned treatises. This section discusses whether the foundation witnesses are sufficiently knowledgeable to satisfy the foundation fact approach.

\section{Prior Statements Made by a Testifying Declarant/Witness}

Rules $801(d)(1)$ and $803(5)$ obligate the proponent to produce the declarant as a witness to admit four types of her own prior statements. Rule 801(d)(1) defines prior statements of witnesses narrowly. ${ }^{166}$ Its

164. See Morgan, supra note 4 , at 188 (arguing that the most important servicc of crossexamination is exposing errors of perception and memory).

165. A functional definition of hearsay under the foundation fact approach tests whether the out-of-court statement should be subject to special legal regulation because of the trier of fact's special function of evaluating the testimonial qualities of the specific declarant to determine the probative force of the specific statement. In Park's terminology, this would be a "declarantoriented" definition. Park, supra note 154, at 424.

The original edition of McCormick's treatise defined hearsay as "testimony in court or written evidence, of a statement made out of court, such statement being offered as an assertion to show the truth of matters asserted therein, and thus resting for its value on the credibility of the out-of-court asserter." C. MCCORM1CK, supra note 5, $\S 225$, at 460 (footnote omitted). Park notes that this definition conflates "declarant-oriented" and "assertion-oriented" definitions of hearsay. Park, supra note 154, at $425-26$. The current edition of McCormick acknowledges that defining hearsay by the policy underlying the rule of exclusion might conflict with the narrower "truth of the matter asserted" definition. MCCORMICK, supra note $2, \S 246$, at 730 .

In the terminology of this Article, the functional definition requires foundation facts where the relevance of oral statements requires the trier of fact to evaluate and rely on the know/edge of the delarant about a case-specific fact.

Other commentators have proposed alternative definitions of what types of unspoken conduct and assertions should constitute hearsay. See, e.g., M. Graham, HandBook of FEdERAL EVIDENCE $\S 801.6$, at 706 (1981); R. LEMPERT \& S. SALTZBURG, supra note 46, at 359; Booker \& Morton, supra note 8, at 42; Finman, Implied Assertions as Hearsay: Some Criticisms of the Uniform Rules of Evidence, 14 STAN. L. REv. 682 (1962); Morgan, supra note 4, at 216; Wcllborn, supra note 52, at $92 \mathrm{n} .191$ (proposing a broad definition of "the matter asserted" which has been adoptcd in TEX. R. EvID. 801(c)); see also Seidelson, supra note 158, at 775 (treatment of indirect speech should be rejected by courts, and "implied assertions should be deemed to retain their traditional characterization as hearsay.").

166. These statements are exempt not on the basis of circumstantial guarantees of 
restrictions function to underadmit, preventing the trier from evaluating out-of-court statements when the trier is functionally able to do so. Subsection (A) admits prior inconsistent statements, but only those made at a hearing, under oath, and subject to penalty of perjury. ${ }^{167}$ This limitation precludes the trier's substantive use of inconsistent statements made in most out-of-court situations. ${ }^{168}$ Subsection (B) admits prior consistent statements only if the testimony of the declarant/witness has been attacked in particular ways. ${ }^{169}$ And subsection (C) restricts the subject of a declarant's statement of identification solely to "persons." 170 To the extent that these restrictions are based on external generalizations about reliability or on arguments of expedience, they disserve the hearsay values of operational accuracy, independence, and fairness. ${ }^{171}$

Under the foundation fact approach, admission of hearsay statements by declarant/witnesses is not subject to such tortured classifications. However, the proponent's production of the declarant/witness does not automatically operate to admit all prior statements. ${ }^{172}$ The basic process standard of admission must still be satisfied, presumably by the declarant/witness if she actually remembers the circumstances that

trustworthiness underlying rule 803 and 804 exceptions, but because the presence of the declarant serves as a "general safeguard." FED. R. EVID. 801(d)(1) advisory committee's note.

167. FeD. R. Evid. 801(d)(1)(A).

168. Some states permit the trier to evaluate all prior inconsistent statements made by testifying declarants for substantive use. See, e.g., CAL. Evid. CoDE $\S 1235$ (West 1966). Many commentators support such a rule. See e.g., M. GRAHAM, supra note 55, at 118-19. The restrictions in subsection (A) concern reliability and the ineffectiveness of in-court cross-examination when the declarant denies or forgets making the statement.

169. FED. R. EvID. 801(d)(1)(B). The common law generally admitted prior consistent statements only for their relevance to the declarant/witness' credibility. MCCoRMICK, supra note 2, $\S 251$, at $744-45,747$. The limitation imposed on prior consistent statements under subsection (B) is an example of how considerations extrinsic to hearsay values can restrict the use of evidence that otherwise would be admissible under hearsay policy.

170. FED. R. Ev1D. 801(d)(1)(C).

171. The restrictions could also be based on other values extrinsic to hearsay policy. For example, prior consistent statements might be generally excluded to increase efficiency in the trial process or to deter out-of-court behavior, such as manufacturing consistent statements prior to trial solely for tactical purposes. These policies could also apply under the foundation fact approach, since satisfying hearsay values does not guarantee admission. The rest of evidence law, and other values at stake in adjudication, would still apply. Thus, prior consistent statements might be excluded pursuant to rule 403 if they are cumulative, time-consuming, or distracting. See FED. R. Evid. 403.

172. In contrast, both the Model Code of Evidence and the Uniform Rules of Evidence would have automatically admitted such declarations if the prior statements were oral. See MODEL CODE OF EVIDENCE Rule 503(b) (1942) (admitting all prior consistent, inconsistent, and other statements even if the declarant does not testify about the relevant events at trial due to loss of memory or denial); UNIF. R. EvID. 63(1) (1953) (admitting "a statement previously made by a person who is present at the hearing and available for cross-examination with respect to the statement and its subject matter"). Commentators assumed that this language intended to admit prior statements even when the declarant denied having made the statement. CALIForNIA LAW REvision COMmission, Tentative Recommendation and a Study Relating to the Uniform Rules of Evidence, in 4 Reports, Recommendations and Studies 430 (1963). 
affected her perception of the relevant event, her memory of it, and her making of the out-of-court statement. The declarant/witness may have forgotten these circumstances or may deny either having seen the event or having made a statement about it. In either case, she is not a knowledgeable process foundation witness under the basic foundation fact standard.

In practice, the admission of witnesses' prior inconsistent and consistent statements under subsections (A) and (B) of rule 801(d)(1) usually satisfies the foundation fact standard. These subsections presume testimony about the relevant event; thus, the declarant/witness remembers it and is knowledgeable about the circumstances affecting her perception opportunity and memory. If the declarant has forgotten her perception opportunity, or denies or forgets making the prior statement, another knowledgeable foundation witnesses must testify. ${ }^{173}$ Statements "of identification of a person" admitted under subsection (C) are usually used to corroborate an in-court identification. The declarant who testifies that she perceived a person and then made a statement identifying that person will usually remember the surrounding circumstances. Again, if the declarant/witness does not remember the identification, other process foundation witnesses must be produced. ${ }^{174}$

173. This calls into question some opinions admitting prior statements when the declarant/ witness cannot testify about the relevant event because she claims a loss of memory. See, e.g., United States v. Williams, 737 F.2d 594, 608 (7th Cir. 1984), cert. denied, 470 U.S. 1003 (1985); United States v. Russell, 712 F.2d 1256, 1258 (8th Cir. 1983); People v. Green, 3 Cal. 3d 981, 988-89, 479 P.2d 1002-03, 92 Cal. Rptr. 494, 498-99, cert. dismissed, 404 U.S. 801 (1971); People v. O'Quinn, 109 Cal. App. 3d 219, 225-26, 167 Cal. Rptr. 141, 144 (1980), cert. denied, 450 U.S. 928 (1981). Courts that find these claims of memory loss untrue have treated the declarant/witness's in-court behavior as an implied denial of a prior statement she made about the event. Courts then admit the prior statement as "inconsistent" with the in-court behavior. However, as pointed out in United States v. Owens, 789 F.2d 750 (9th Cir. 1986), cert. granted, 107 S. Ct. 1284 (1987), all of these cases involved witnesses whose memory loss was "so incredible as to not be believable." Id. at 759 n. 10 .

Neither these cases nor the comment to Model Rule 503 discusses how the trier should evaluate the reliability of the declarant's perception if the declarant/witness denies remembering the relevant event. MODEl CODE of EvidenCE Rule 503 comment (1942).

Usually the declarant admits making the prior statement and remembers the surrounding circumstances. If the declarant forgets the statement or denies making it, however, the court should require the testimony of another foundation witness who overheard it. A requirement that this foundation witness be knowledgeable about the declarant's circumstances could be added to rule $801(d)(1)$ as follows: The declarant or other witness must be subject to cross-examination regarding the circumstances at the time the declarant made the statement.

174. If a law enforcement officer describes the out-of-court identification, the person who made it must be present and subject to cross-examination. See United States v. Elemy, 656 F.2d 507 (9th Cir. 1981). Drawings and photos of a person can also be the subject of the identification. United States v. Lewis, 565 F.2d 1248, 1251-52 (2d Cir. 1977), cert. denied, 435 U.S. 973 (1978). M. GRAHAM, supra note 55, at 139-40, notes that subsection (C) does not require that a correct in-court identification be made, or even be attempted. Graham contends that in these circumstances, the rationale of subsection (C) does not apply and the statement of identification should, therefore, be excluded. Id. at 139. Under the foundation fact approach, the trier of fact can evaluate such statements if other foundation witnesses testify. 
The final type of admissible prior statements of a declarant/witness is known as past recollection recorded, defined by rule $803(5)$. Under this categorical exception, the proponent must produce the declarant in court to establish that the declarant's inadequate memory justifies admission of a prior statement reduced to writing. Conforming the written statement to rule 803(5)'s requirements - that it was made with a fresh memory and was a correct recording ${ }^{175}$ _necessitates production of a foundation witness knowledgeable about the circumstances affecting the declarant's memory ${ }^{176}$ and the making and recording of the statement. ${ }^{177}$ This partially satisfies the foundation fact approach. If the declarant remembers her perception opportunity, ${ }^{178}$ the foundation would be complete.

In some cases, no process witness with knowledge of the declarant's perception opportunity may be available. This may even include the declarant who has forgotten or who denies the prior statement. Under both rule $801(\mathrm{~d})(\mathrm{I})$ and rule $803(5)$, the adjusted foundation might be satisfied. Each statement would have to assert facts pertinent to the declarant's perception, as in Example $6 .{ }^{179}$ The declarant is already present in court as a witness, and she obviously qualifies as an identification foundation witness. ${ }^{180}$

175. FED. R. Evid. 803(5).

176. In the reported cases, the declarant herself usually testifies that the relevant events were fresh in her memory when her prior statement was recorded. See, e.g., United States v. Williams, 571 F.2d 344, 346, 348 (6th Cir.) (declarant testified unequivocally that his conversations with defendant, about which he gave a statement to a Secret Service Agent, were fresh in his mind when he signed the statement), cert. denied, 439 U.S. 841 (1978). The courts have liberally interpreted the freshness requirement in rule $803(5)$ and have rejected the traditional rule requiring contemporaneity. Indeed, the federal courts have considered lapse of time to be only one factor in determining freshness. See, e.g., United States v. Patterson, 678 F.2d 774, 777 n.2, $778-79$ (9th Cir.) (declarant's prior statement to grand jury made 10 months earlier), cert. denied, 459 U.S. 911 (1982).

177. See, e.g., United States v. Sawyer, 607 F.2d 1190, 1193 (7th Cir. 1979) (revenue officer's testimony tended to show that both his memorandum about a telephone conversation with defendant and the memorandum's later transcription were accurate), cert. denied, 445 U.S. 943 (1980). If the "correct reflection" requirement applies only to insure that the record or memorandum was an accurate transcription of the declarant's statement, the foundation witness may not know about the circumstances affecting the declarant's making of the statement. Such a witness would not satisfy the foundation fact approach.

178. Even if the declarant cannot remember the details of the relevant event, she often is able to testify about her opportunity for perception under the circumstances then existing. This testimony can provide the foundation facts needed for evaluation. See, e.g., United States v. Marcantoni, 590 F.2d 1324, 1330 n.6 (5th Cir.) (declarant provided useful incidental information when he testified as to what he observed firsthand during the course of his search of defendant's residence), cert. denied, 441 U.S. 937 (1979).

179. See, e.g., United States v. Patterson, 678 F.2d 774, 778 (9th Cir.) (declarant's grand jury testimony that defendant had made incriminating statements seemed likely to include the circumstances under which the declarant heard them), cert. denied, 459 U.S. 911 (1982).

180. See supra text accompanying note 131. 


\section{Business Records}

Business records are defined by rule 803(6) as records made "at or near the time" of an event, by "a person with knowledge, if kept in the course of a regularly conducted business activity, ... if it was the regular practice of that business activity to make the ... record."181 Rule 803(6) also explicitly requires that these facts be "shown by the testimony of the custodian or other qualified witness." 182 Thus, conforming a business record to these requirements would ordinarily satisfy the foundation fact approach's basic process standard of admission, as in Examples 3 and 4.183

If a declarant recorded an event while on the job, the job circumstances encompass the declarant's process of perceiving, remembering, and making the statement. The identity of the declarant, or of multiple declarants if more than one person created the record, need not be revealed. The facts must demonstrate that the declarants had an opportunity to perceive, remember, and record the events while acting in a business-related capacity. ${ }^{184}$ The proponent's qualified witness will usually know about these facts. ${ }^{185}$ Thus, rule 803(6) conforms to the foundation fact approach if it is strictly enforced to require that a witness be produced, ${ }^{186}$ and if the witness' knowledge extends to all process

181. FED. R. Evid. 803(6).

182. Id.

183. See supra text accompanying notes $57-58$.

184. Business documents prepared by in-house declarants are routinely admitted upon facts showing a job description. See, e.g., Capital Marine Supply, Inc. v. M/V Roland Thomas, II, 719 F.2d 104, 105-06 (5th Cir. 1983) (manager of "industrial receivables" department of credit company introduced computerized records of mortgage payments and explained how employees entercd information into the computer and cross-checked computer listing with manual ledger). The identity of outside sources of information recorded in the business record need not be revealed if they too are acting under a business duty of accuracy. See, e.g., United States v. Vacca, 431 F. Supp. 807, 812 (E.D. Pa. 1977) (admitting information regarding finder's fee recorded by title clerk since it originated with parties to the transaction), aff'd, 571 F.2d 573 (3d Cir. 1978).

185. The presence of the foundation witness may even provide sufficient opportunity for crossexamination, thereby protecting a criminal defendant's right to confrontation. United States v Peden, 556 F.2d 278, 281 (5th Cir.), cert. denied, 434 U.S. 871 (1977).

186. One court permitted the facts requisite to comply with rule 803(6) to be proved by documentary and other circumstantial evidence, including the proferred business record itself, thus eliminating the need for a live witness. In Re Japanese Elec. Prods. Antitrust Litig., 723 F.2d 238, 288 (3d Cir. 1983), rev'd on other grounds sub nom. Matsushita Elec. Indus. Co. v. Zenith Radio Corp., 106 S.Ct. 1348 (1986). This approach has not been widely followed.

Allowing a party to lay the foundation, or even to supplement it, through deposition testimony would not be fair unless the opponent had prior access to the deponent. See FAA v. Landy, 705 F.2d 624, 633 ( $2 \mathrm{~d}$ Cir.) (foundation for aircraft log book at least partly provided by pilot's deposition testimony), cert. denied, 464 U.S. 895 (1983).

The requirement of a knowledgeable foundation witness should also apply to rule 803(7), which admits evidence of a lack of an entry in a business record to prove thic nonoccurrence of an event. FED. R. Ev1D. 803(7). The trier's need for foundation facts to evaluate the meaning of the record is no less here than in a rule 803(6) situation. See Monarch Fed. Sav. and Loan Ass'n v. Genser, 156 
circumstances. ${ }^{187}$

Rule 803(6) further provides that trial judges can exclude business records for "lack of trustworthiness" in their sources of information or in the method and circumstances of their preparation. ${ }^{188}$ Judges rarely invoke this power based on their own evaluation of the testimonial qualities of individual declarants, unless they are acting in their capacity as the trier of fact. ${ }^{189}$ Instead, judges base exclusion on gaps in the knowledge of the foundation witness about some aspect of the categorical facts required by rule $803(6) .{ }^{190}$ Judges could use this discretionary power of exclusion to require proponents of business records to produce foundation witnesses who conform to the basic foundation fact standard.

\section{Learned Treatises}

Statements contained in learned treatises about history, medicine, or other sciences or arts may be read into evidence under rule 803(18) if a testifying expert witness relies on the treatise, or if the opponent chooses to cross-examine the expert about it. ${ }^{191}$ Thus, an expert knowledgeable in the subject matter of the treatise must be produced to serve as a foundation witness. The expert witness can testify about the reliability of the declarant/author of the treatise, since presumably the expert is familiar with the nature of the underlying research or study. ${ }^{192}$ The trier may, in

N.J. Super. 107, 383 A.2d 475 (1977) (proving a failure to make mortgage payments from lack of an accounting entry held admissible under N.J. R. EviD. 63(13)).

187. A gap in the process foundation may exist if, for example, the foundation witness was not employed at the same place of business as the original declarant. Yet some courts admit the testimony of such witnesses. See, e.g., United States v. Carranco, 551 F.2d 1197, 1199-1200 (10th Cir. 1977) (business that was the custodian of the records integrated records in question into its own system and relied upon them in day-to-day operations). Employment status is irrelevant, so long as the foundation witness knows how the records are produced. See United States v. Hathaway, 798 F.2d 902, 906 (6th Cir. 1986) (noting that there is "no reason why a proper foundation . . . cannot be laid [by a] . . . person outside the organization").

188. FED. R. EV1D. 803(6).

189. Apparently the only reported ease where a court excluded a purported business record on a finding of the declarant's testimonial untrustworthiness involved a bench trial. In E.F. Hutton \& Co. v. Penham, 547 F. Supp. 1286 (S.D.N.Y. 1982), after determining that all three of plaintiff's customer/witnesses were untrustworthy, the court found that records prepared by them were similarly untrustworthy and therefore could not be accepted as business records. Id. at 1294. This case, however, also involved a categorical problem: the records were produced by a third-party declarant who was not under a business duty to be sincere and accurate. See also Johnson v. Lutz, 253 N.Y. 124, 170 N.E. 517 (1930) (bystander's statement recorded in a police report inadmissible under $\$ 374-\mathrm{a}$ of New York's Civil Practice Act because speaker had no duty to impart such information).

190. Some courts have gone so far as to equate "lack of trustworthiness" with gaps in the foundation. See, e.g., United States v. Dreer, 740 F.2d 18, 20 (11th Cir. 1984); Vesper Constr. Corp. v. Rain for Rent, Inc., 602 F.2d 238, 242 (10th Cir. 1979).

191. FED. R. Ev1D. 803(18).

192. See, e.g., Burgess v. Premier Corp., 727 F.2d 826, 833-34 (9th Cir. 1984) (expert qualified by "experience and investigations" in cattle investments can qualify books on the subject by the "preeminent industry expert"); Johnson v. William C. Ellis \& Sons Iron Works, Inc. 609 F.2d 820, 
turn, have to evaluate the expertise of the declarant/author to make judgments about any of the statements of original perceiving declarants that are contained in the treatise, as in Example 11. ${ }^{193}$ Foundation facts about this expertise are available, since rule $803(18)$ requires that the declarant/author's credentials be known to the testifying expert. ${ }^{194}$

Thus, a witness knowledgeable about the process foundation of a treatise must be offered to the trier and to the opponent along with any treatise statements. ${ }^{195}$ This is consistent with the foundation fact approach to hearsay. The Advisory Committee's note to rule 803(18) justifies imposing this obligation because the treatise may be "misunderstood and misapplied without expert assistance and supervision."196 The foundation fact approach recognizes the usefulness of a knowledgeable foundation witness for the trier's evaluation of any hearsay statement.

\section{Hearsay of a Single Declarant}

The exceptions and exemptions admitting hearsay statements of a single declarant do not consistently obligate the proponent to produce a knowledgeable process foundation witness. Proponents offer most oral hearsay statements into evidence through the testimony of witnesses who overheard them. The proponent of hearsay must also prove the facts necessary to conform the statement to a categorical exception. These facts, if admissible to the trier, function as foundation facts for evaluation of the reliability of the hearsay statement. However, the narrow focus of the exceptions on sincerity means that foundation facts about the declarant's perception opportunity are commonly lacking. Some exceptions admit documentary hearsay witlout any foundation witness at all.

This section compares the practical operation of each categorical exception with the foundation fact approach in terms of the kinds of facts the proponent must produce to conform hearsay to the exception. It discusses groups of exceptions and exemptions that impose similar burdens, and presents suggestions for reinterpreting or revising the rules within the overall categorical structure.

822-23 (5th Cir. 1980) (safety codes and standards admitted through the testimony of an expert who had offered opinions in several negligence cases).

193. See supra text accompanying notes 143-44.

194. A party may concede the validity of the declarant/author's credentials. See, e.g., Dawson v. Chrysler Corp., 630 F.2d 950, 961 (3d Cir. 1980) ("Well, I have no reason to doubt the[ 1 test data reflected in [the] reports," referring to the reports prepared for the U.S. Department of Transportation on automobile crashworthiness), cert. denied, 450 U.S. 959 (1981). A party may also dispute these credentials. See, e.g., Hemingway v. Ochsner Clinic, 608 F.2d 1040, 1047 (5th Cir. 1979) (text called "Medical-Surgical Nursing," written by two registered nurses, was not admitted due to lack of testimony from defendants' physician/experts that it was reliable).

195. See, e.g., Dartez v. Fibreboard Corp., 765 F.2d 456, 465 (5th Cir. 1985) (medical articles in exhibit not properly admitted under rule $803(18)$ without use of expert's testimony).

196. FED. R. Evid. 803(18) advisory committee's note. 


\section{Present Sense Impressions}

Conforming a hearsay statement to the exception for present sense impressions stated in rule $803(1)^{197}$ will ordinarily satisfy the foundation fact approach. Proving that a statement "describing or explaining" an event or condition made "while the declarant was perceiving the event or condition, or immediately thereafter," 198 requires the proponent to show that the event, the declarant's perception of it, and the declarant's stateinent were contemporaneous. ${ }^{199}$ Thus, it is likely that a witness who reports hearing the statement will also have observed the declarant while she perceived the event, as in Example 2. ${ }^{200}$ In foundation fact terminology, if this foundation witness knows about the circumstances surrounding the declarant's perceiving an event, remembering it, and making a statement about it, ${ }^{201}$ the basic process standard of the foundation fact

197. FED. R. EvID. 803(1).

198. Id.

199. See United States v. Cruz, 765 F.2d 1020, 1024 (11th Cir. 1985) (excluding federal agent's statements to defendants after meeting with accused cocaine dealer because statements were not made immediately after the meeting, and were perhaps made days later); Pfeil v. Rogers, 757 F.2d 850, 861 (7th Cir. 1985) (excluding statements by alleged murder witness because statements were made a substantial period, at least days, after the shooting), cert. denied, $106 \mathrm{~S}$. Ct. 1513 (1986); United States v. Cain, 587 F.2d 678, 680-81 (5th Cir. 1979) (excluding state trooper's testimony as to citizens' band radio transmission that identified defendants on ground that transmitter almost certainly did not make the statement immediately after observing the defendants), cert. denied, 440 U.S. 975 (1979); Wolf ex rel. Wolf v. Proctor \& Gamble Co., 555 F. Supp. 613, 620 (D.N.J. 1982) (excluding consumer complaints received by mail and telephone partially on the ground that the statements probably were not made immediately after complainants suffered symptoms of toxic shock syndrome).

200. See supra text accompanying notes 55-57.

201. See, e.g., United States v. Medico, 557 F.2d 309 (2d Cir.), cert. denied, 434 U.S. 986 (1977). The court admitted, under the residual exception, a hearsay statement made by a bank employee, who had been given the defendant bank robbers' license plate number by a customer. The customer had in turn received the information from a youth viewing the car. The court alternatively found the hearsay statement could be admitted under rule 803(1) because both the customer and the youth were at the scene and the bank employee could have seen the youth's lips moving. Id. at 315-16. Professor WValtz comments that it is a "fair inference that [the bank employee] was a percipient observer of all the events leading up to and following the robbers' escape." Waltz, supra note 55, at 886.

In a number of recent cases, the foundation witness did not perceive the event itself but observed the declarant perceiving it and then speaking about it. United States v. Portsmouth Paving Corp., 694 F.2d 312, 323 (4th Cir. 1982) (foundation witness standing in declarant's office doorway while declarant had a telephone conversation allowed to testify about declarant's immediate account of the conversation); United States v. Peacock, 654 F.2d 339, 350 (5th Cir. 1981) (foundation witness described a telephone conversation recounted to her by her deceased husband immediately after the conversation ended), aff'd in part and vacated in part on other grounds, 686 F.2d 356 (5th Cir. 1982), cert. denied, 464 U.S. 965 (1983). Given the declarant's immediate recounting of the substance of the conversation, both courts assumed that the witness was probably present as the declarant spoke on the telephone.

Finally, where the declarant herself testifies as the foundation witness, as in Example 1, the jury is presented with all the circumstances surrounding the declarant's perception and making of the statement. This situation presents the most complete satisfaction of the foundation fact approach. See Michaels v. Michaels, 767 F.2d 1185, 1201 (7th Cir. 1985) (foundation witness was the author of 
approach is satisfied.

The common law exception out of which rule 803(1) evolved arguably required that a present sense impression be accompanied by a testifying foundation witness who had also observed the relevant event. ${ }^{202}$ Usually, this witness also observed the declarant perceiving the event, thus completing the process foundation. But this kind of corroborating witness is neither explicitly required by rule $803(1)$ nor consistently produced in practice. ${ }^{203}$ When the foundation witness is not present when the declarant perceives the event, the basic process foundation is not complete. This currently occurs when judges relax the requirement of strict contemporaneity between the declarant's perception and speech, thereby depriving the trier of information about the declarant's perception opportunity. ${ }^{204}$

Applying the foundation fact approach to this exception, trial judges can insist that contemporaneity be proved under the existing terms of rule $803(1)$. This will require the proponent to produce a foundation witness knowledgeable about the declarant's perception opportunity. If facts about the perception opportunity are asserted in the hearsay statement itself, and no foundation witness is available to testify, then the adjusted standard ${ }^{205}$ would permit substitution of an identification foundation witness. ${ }^{206}$

the telex held admissible under 803(1)), cert. denied, 106 S.Ct. 797 (1986); United States v. Kehoe, 562 F.2d 65, 70 (lst Cir. 1977) (admitting under rule 803(1), a grand jury recording secretary's testimony about the contents of her notes, which reflected that defendant had taken the oath).

202. In the leading state case, Houston Oxygen Co. v. Davis, 139 Tex. 1, 161 S.W.2d 474 (1942), the court admitted the statement of the declarant, recounted by the declarant and two passengers in her car, about a speeding car that passed them on the road: "[T]hey must have been drunk, that we would find them somewhere on the road wrecked if they kept that rate of speed up." Id. at $5,161 \mathrm{~S} . \mathrm{W} .2 \mathrm{~d}$ at 476 . In this case, both the declarant herself and the two passengers could fully describe the circumstances surrounding the declarant's perceiving the car and making the statement. See MCCORMICK, supra note 2, $\S 298$, at 860 (presence of foundation witness furnishes guarantees of reliability because witness will "provide a check on the accuracy of the declarant's statement").

203. The text of rule $803(1)$ is silent about whether a corroborating witness is required. The advisory committee's note to rule 803 (1) acknowledges that if the foundation witness is not the declarant, she "may be examined" as an aid in evaluating the statement. FED. R. Evid. 803(1) advisory committee's note; cf. Brown v. Tard, 552 F. Supp. 1341, 1350-51 (D.N.J. 1982) (admitted testimony under N.J. R. EvID. 63(4)(a) of murder victim's boyfriend who stated that, on the day of the murder, the victim told him on the telephone that "a man" was in her apartment flxing her air conditioner).

204. See, e.g., United States v. Blakey, 607 F.2d 779, 785-86 (7th Cir. 1979) (admitting statement of defendant described by deceased declarant "between several minutes and 23 minutes" after relevant event); Goldman v. St. Francis Hospital, No. 80 Cir. 1729 (S.D.N.Y. Aug. 31, 1981) (LEXIS, GenFed library, Dist File) (admitting decedent's wife's testimony recounting what a hospital employee told her about her husband's death, despite her complete absence of knowledge about the declarant's identity); Waltz, supra note 55, at 886-87 (too great a time-lapse between the event and the statement can preclude availability of an "equally percipient witness").

205. See supra text accompanying notes 130-34.

206. Two cases illustrate the use of the adjusted foundation. In each, a declarant's description 


\section{Medical Statements, Dying Declarations, and Excited Utterances}

The categorical terms of the exceptions for statements made for the purpose of medical diagnosis or treatment, ${ }^{207}$ for dying declarations, ${ }^{208}$ and for excited utterances ${ }^{209}$ each describe circumstances existing when the declarant made the statement. In order to prove the requisite circumstances, which differ for each particular category, the proponent will usually have to produce a witness who saw what was happening when the declarant spoke. But these categorical exceptions require no information about the declarant's circumstances when she perceived the events she later speaks about. As a result, hearsay statements about hotly disputed evidence are admitted under these exceptions without foundation facts enabling the trier to evaluate the reliability of the declarant's perception.

For example, statements that describe a victim's assault are admitted under rule 803(4) as "reasonably pertiment to diagnosis or treatment." 210 Proof of this categorical term usually requires the testimony of the doctor to whom the statement was made. ${ }^{211}$ Tlius, in foundation fact terminology, many foundation facts about the declarant's circumstances

of her husband's or boyfriend's threat is offered in the prosecution of the husband/boyfriend for the declarant's subsequent murder. In People v. Green, 27 Cal. 3d 1, 609 P.2d 468, 161 Cal. Rptr. 1 (1980), "the witness was prepared to testify that [the declarant/victim] stated to her she had a telephone conversation with defendant on the morning of October 11 in which she told defendant she intended to get an annulment and he replied he would kill her if she left him." Id. at 23, 609 P.2d at 480, 164 Cal. Rptr. at 13. Due to the time elapsed between the declarant's perception of defendant's threat and her out-of-court statment about it, the statement could not have been admitted as a present sense impression. Although the court noted that the statement was not subject to a hearsay objection because it was not offered for the truth of the matter asserted, if it had been offered for its truth, it should not have been admitted. Id. But in Commonwealth v. Coleman, 458 Pa. 112, 326 A.2d 387 (1974), the victim's statement about a similar threat was admitted as a present sense impression. The foundation witness testified that her daughter, the declarant/victim, "telephoned her mother ... saying that Coleman would not let her leave the apartment, that he would hang up the telephone and that he was going to kill her." Id. at 114,326 A.2d at 388 .

These two cases treated the victim's hearsay statement differently due to the inflexible nature of the categorical exceptions. In Green, too much time had elapsed between the statement and the reported threat. Under the foundation fact approach, both statements could be admissible under the adjusted foundation. In both cases, the declarants describe the context in which they perceived and remembered the threat. Green, $27 \mathrm{Cal}$. 3d at 13,609 P.2d at 474, $164 \mathrm{Cal}$. Rptr. at 7; Coleman, 458 $\mathrm{Pa}$. at 119, $326 \mathrm{~A} .2 \mathrm{~d}$ at 390 . The foundation witness in each case could testify about the circumstances at the time each declarant made her statement. Moreover, in each case, the foundation witness (declarant's friend in Green and declarant's mother in Coleman) could have qualified as an identification witness.

207. FED. R. Ev1D. 803(4).

208. FED. R. EVID. 804(b)(2).

209. FED. R. Evid. 803(2).

210. FED. R. EvID. 803(4); see, e.g., United States v. Nick, 604 F.2d 1199, 1201-02 (9th Cir. 1979) (where three-year-old sexual assault victim described assault to examining physician, court permitted doctor to testify to those portions of the child's statements relevant to the cause of injury, omitting the identity of the assailant).

211. See, e.g., Nick, 604 F.2d at 1201-02. 
when making the statement, including appearance and demeanor, are available from this foundation witness. However, nothing in rule 803(4) requires that the witness be knowledgeable about either the declarant's perception opportumities or the declarant's identity, even when the statements also include details about the events causing the declarant's mjuries. ${ }^{212}$

The exception for dying declarations concerning the cause of the declarant's death im rule 804(b)(2) requires facts to show that the declarant beheved $\mathrm{m}$ her impending death. ${ }^{213}$ When these facts are obtained from a witness who observed the declarant's condition or overheard the declarant's own statements, this witness will be a source of foundation facts about the circumstances existing when the declarant spoke. ${ }^{214}$ But such a witness will not necessarily know anything about the declarant's perception of the facts contamed in the dymg declaration. ${ }^{215}$

Excited utterances, admissible under rule 803(2), typically require testimony from a witness to show that the declarant spoke excitedly due to an event that itself must be shown to be startling. ${ }^{216}$ The declarant's

212. See United States v. Renville, 779 F.2d 430, 435-39 (8th Cir. 1985) (doctor permitted to testify to sexually abused child's attributing fault to a member of the child's immediate family where the child's motive was unassailable and where the information was reasonably pertinent to his psychological health and treatment); United States v. Iron Thunder, 714 F.2d 765, 772 (8th Cir. 1983) (examining doctor allowed to testify to a rape victim's statements made during a hospital examination even though doctor's examination and questioning of victim were done pursuant to standardized protocol largely designed to prepare for criminal prosecution); United States v. Iron Shell, 633 F.2d 77, 82-85 (8th Cir. 1980) (where a nine-year-old sexual assault victim told story of her assault to doctor while being examined at hospital, doctor allowed to repeat victim's statements at trial), cert. denied, 450 U.S. 1001 (1981).

213. Only three reported federal cases have applied rule $804(\mathrm{~b})(2)$ since its adoption. See Pfeil v. Rogers, 757 F.2d 850, 861 (7th Cir. 1985); Motta v. Samuel Weiser, Inc., 598 F. Supp. 941, 944 (D. Me. 1984); United States v. Layton, 549 F. Supp. 903, 918 (N.D. Cal. 1982), aff'd in part and rev'd in part on other grounds, 720 F.2d 548 (9th Cir. 1983), cert. denied, 465 U.S. 1069 (1984). While death need not actually occur, belief in the certainty of death remains an indispensable requirement of rule 804(b)(2). See FED. R. Ev1D. 804(b)(2) advisory committee's note ("[u]navailability is not limited to death"); $4 \mathrm{~J}$. WEINSTEIN \& M. BERGER, supra note 12, 凤 804(b)(2)[01], at 804-112. Belief in impending death may be proven by the declarant's own statements or through circumstantial evidence such as the apparent fatal quality of the wound. MCCormick, supra note $2, \S 282$, at 829 .

214. Where no foundation witness testifies about the declarant's specific circumstances, the requirements of the foundation fact approach would not be satisfied. E.g., Motta, 598 F. Supp. at 944 (witness to declarant's dying declaration described it in a letter and did not testify at trial).

215. E.g., Pfeil, 757 F.2d at 858, 861 n.18 (family members who witnessed declarant's statements on the day of her suicide did not have personal knowledge of declarant's perception opportunity).

216. Typically a foundation witness describes the circumstances surrounding the declarant's statement, including the declarant's nervous or excited condition and, where known, any events leading up to the statement. See, e.g., Haggins v. Warden, Fort Pillow State Farm, 715 F.2d 1050, 1058 (6th Cir. 1983) (admitting statements made by sexually abused cliild to two nurses and a policc officer over an hour after the child suffered serious injuries, but while the child was still experiencing pain), cert. denied, 464 U.S. 1071 (1984); United States v. Golden, 671 F.2d 369, 371 (10th Cir.) (admitting statement made to grandmother by victim 15 minutes after he was allegedly hit and 
statement usually describes the event and attributes fault or liability. Where the witness also has knowledge about the declarant's perception of the startling event, the basic standard of the foundation fact approach is complete. ${ }^{217}$ But this is a fortuity. Typically, the witness only observes the declarant while speaking, thus depriving the trier of foundation facts needed to evaluate the declarant's perception of the crucial events.

For these three categories of hearsay, an absence of facts about perception is particularly detrimental. The basic foundation fact standard of admission would be satisfied by the production of a foundation witness knowledgeable about the circumstances affecting the declarant's perception and memory. But these three categories contain no doctrinal leeway allowing judges the discretion to require an additional foundation witness. Therefore, these categories should be revised by adding the obligation explicitly.

A revised categorical rule could admit statements about specific subjects in categorically defined situations, if proof of the declarant's circumstances while perceiving the relevant event is produced by a knowledgeable foundation witness. The declarant herself can always serve as the foundation witness knowledgeable about lier perception opportunity. ${ }^{218}$ Only if the declarant is unavailable could the proponent use the adjusted foundation by substituting an identification witness, as in Examples 5 and 6.219

injured by defendant police officer and immediately after a twelve mile, 120 mile per hour drive to grandmother's house), cert. denied, 456 U.S. 919 (1982); Hilyer v. Howat Concrete Co., 578 F.2d 422, 425-26 (D.C. Cir. 1978) (admitting police officer's contemporaneous notes recording statement of decedent's coworker, made 15 to 45 minutes after decedent's fatal accident, where coworker described himself as "excited" and "upset" and wherein he blamed the decedent for the accident).

217. These cases involve statements that qualify as present sense impressions as well as excited utterances. See David v. Pueblo Snpermarket, Inc., 740 F.2d 230, 235 (3d Cir. 1984) (foundation witnesses observed declarant perccive startling event-slip and fall by plaintiff-before declarant made the utterancc, although the court noted the trial judge was "at the outer boundary of his discretion"); United States v. Lawrencc, 699 F.2d 697, 703-04 (5th Cir.) (foundation witness was present when defendant threatened declarant, giving rise to declarant's excited utterance), cert. denied, 461 U.S. 935 (1983); United States v. Napier, 518 F.2d 316, 317-18 (9th Cir.) (foundation witness was present when declarant reacted with distress and horror when viewing her assailant's picture for the first time), cert. denied, 423 U.S. 895 (1975).

218. The declarant testifies in some cases involving her excited utterances. See Lawrence, 699 F.2d at 704 (noting in dictum that had the hearsay been improperly admitted, prejudice was reduced when declarant was called as a witness); Hilyer, 578 F.2d at 427 (where declarant was crossexamined about his statement, issues of "credibility, motivation and probative weight" of the utterance were properly left to jury); Harmon v. Anderson, 495 F. Supp. 341, 344 (E.D. Mich. 1980) (since declarant testified at trial, foundation witness's challenged testimony was, in fact, cumulative). In contrast to the Harmon decision, some commentators have argued that the declarant's in-court testimony regarding hearsay statements should not be considered cumulative. See, e.g., Waltz, supra note 55, at $880-81$. Waltz's argument, couched in terms of present sense impressions, applies equally to excited utterances.

219. See supra text accompanying notes 123-32. The adjusted foundation should be part of the revision proposed supra text accompanying notes 217-18. If no such witness is available, the specific 


\section{Statements About State of Mind, Against Interest, And About Personal History}

The categorical terms of the exceptions for statements about the declarant's state of mind, ${ }^{220}$ against the declarant's interest, ${ }^{221}$ and about personal history ${ }^{222}$ are formulated in terms of the substantive content of the declarant's speech. They are based on broad categorical generalizations about the reliability of perception and sincerity when people speak about particular topics. Under the categorical approach, a proponent may introduce these statements through a witness who only overheard an oral statement or who saw a written statement. No doctrinal terms require production of a witness with knowledge either of the context within which the statements were made or of the declarant's perception.

The trier must still evaluate these types of statements, because the exceptions necessarily overadmit. ${ }^{223}$ The absence of a foundation witness frustrates the trier's evaluation and harms the value of operational accuracy. ${ }^{224}$ These exceptions also demonstrate how the categorical

circumstances affecting the declarant's perception may be provided through the declarant's own statement, and the proponent must then produce a qualified identification witness. This adjusted foundation is not farfetched or complex. First, it requires the declarant's own statement to contain process foundation facts-typically concerning the declarant's opportunity for perception as demonstrated in Examples 5 and 6. See supra text accompanying notes 123-32. This requirement is familiar since current case law holds that if no evidence, including the declarant's own statements, establishes the declarant's perception opportunity, excited utterances should be excluded on grounds of lack of firsthand knowledge. Miller v. Keating, 754 F.2d 507, 510-11 (3d Cir. 1985); United States v. Layton, 549 F. Supp. 903, 915 (N.D. Cal. 1982), aff'd in part and rev'd in part on other grounds, 720 F.2d 548 (9th Cir. 1983), cert. denied, 465 U.S. 1069 (1984).

Second, the adjusted foundation requires an identification witness. Current cases show that the declarant herself often testifies when these three hearsay exceptions are involved. See, e.g., United States v. Renville, 779 F.2d 430, 432, 437-39 (8th Cir. 1985) (declarant's testimony recanted her earlier accusation of sexual assault against defendant; yet physician was allowed to testify to victim's prior statements); United States v. Iron Shell, 633 F.2d 77, 82 (8th Cir. 1980) (nine-year-old declarant's testimony could only partially confirm her prior statements made to her doctor about the circumstances of her assault), cert. denied 450 U.S. 1001 (1981). If the declarant is unavailable to be the identification witness, a person who knows the declarant can satisfy this requirement. See, e.g., United States v. Golden, 671 F.2d 369, 370-71 (10th Cir.) (declarant's statement made to his grandmother), cert. denied, 456 U.S. 919 (1982).

220. FED. R. Ev1D. 803(3).

221. FED. R. EVID. 804(b)(3).

222. FED. R. EviD. 803(13), 804(b)(4). Rule 803(13) admits statements of personal or family history contained in inscriptions, while rule 804(b)(4) admits all such statements without regard to context.

223. Courts have frankly acknowledged this overbreadth. See United States v. DiMaria, 727 F.2d 265, 270-72 (2d Cir. 1984) (overbreadth preferable to preliminary judicial determinations); United States v. Harris, 733 F.2d 994, 1003-05 (2d Cir. 1984) (same); SEC v. Scott, 565 F. Supp. 1513, 1530-31 (S.D.N.Y. 1983) (statement arguably admissible as against declarant's interest unreliable because made by "an inveterate liar and convicted con artist"), aff'd on other grounds, SEC v. Cayman Islands Reinsurance Corp., 734 F.2d 118 (2d Cir. 1984).

224. For example, the facts of Smith v. Updegraff, 744 F.2d 1354, 1366 n.7 (8th Cir. 1984), reveal that the trier had to evaluate a deceased conspirator's statement made after termination of the 
approach undermines the value of independence of the trier of fact by making arbitrary distinctions about what topics of speech are reliable. Categorical exclusion of supposedly less reliable topics precludes the trier from evaluating statements about other common subjects, for example the behavior of pets, ${ }^{225}$ children, or even friends.

Revising these exceptions to conform to the foundation fact approach would not be difficult. The contemporaneity requirement of the present sense impression category could be imposed on the thenexisting state of mind category. ${ }^{226} \mathrm{~A}$ foundation witness who observed the declarant speaking would necessarily observe the declarant both perceiving and remembering her "then-existing" state of mind. Thus, the foundation witness would be knowledgeable about the basic process foundation.

Statements against interest and about personal history would have to satisfy either the basic or the adjusted foundation in order to be admitted under the foundation fact approach. ${ }^{227}$ Both types of statements are currently admitted only under rule 804 , when the declarant is shown to be unavailable. This means that a foundation witness knowledgeable about the declarant's perception may be impossible to produce. Explicit application of the adjusted standard would require that process facts be contained in the declarant's statement, and that the proponent produce an identification witness. In some cases, the definition of a statement against interest under rule 804(b)(3) may already require that testimony about the declarant be given by an identification witness. The statement must be "so far contrary" to the defendant's pecuniary, proprietary, penal, or other litigious interest "that a reasonable man in his position would not have made the statement unless he believed it to be true."228 Courts may compel proof that the declarant was subjectively aware of the danger to her interests, ${ }^{229}$ perhaps requiring a witness who knows the

conspiracy with no information about declarant's perception opportunity. The statement was admitted as against interest under rule 804(b)(3).

225. Statements about the behavior of pet animals are often relevant in litigation over injuries allegedly caused by the pets. See, e.g., Mahlandt v. Wild Canine Survival \& Research Center, Inc., 588 F.2d 626 (8th Cir. 1978).

226. A requirement might be added to rule 803(3) that the statement be proved by a witness capable of testifying about the circumstances existing at the time the statement was made. Cf. Waltz, supra note 55 , at $897 \mathrm{n} .167$ (discussing the requirement of a witness capable of verifying the statement for rule $803(1)$ ).

227. Written statements about personal history admitted through rule $803(13)$ will typically be more than 20 years old. Therefore, the discussion of the foundation fact approach to ancient documents applies to these statements as well. See infra text accompanying notes 230-34.

228. FED. R. Evid. 804(b)(3).

229. See Roberts v. City of Troy, 773 F.2d 720, 725-26 (6th Cir. 1985) (questioning whether the declarant was aware at the time she made her statement that it was not in her best interest, but not deciding the issue because any potential error was deemed harmiess); In re Japanese Elec. Prods. Antitrust Litig., 723 F.2d 238, 299-300 (3d Cir. 1983) (denying admissibility because the plaintiffs 
declarant.

\section{Ancient Documents}

The categorical exception embodied in rule 803(16) requires merely that the proponent prove that a hearsay statement is contained "in a document in existence twenty years or more the authenticity of which is established."230 Courts typically rely on facts concerning the identity of the document's author or the source of its custody to authenticate the document. ${ }^{231}$ But the concept of authentication does not require that the authenticating witness be knowledgeable about the circumstances affecting the perception, memory, sincerity, and language use of the author. Indeed, knowledgeable witnesses may be wholly unavailable, depending upon the age of the writing.

The foundation fact approach requires that if process foundation witnesses are available, the proponent must produce them. If not, the ancient document itself may contain process foundation facts, and an identification witness may be available. The proponent must then produce that witness to satisfy the adjusted standard. The ancient document may also be the type of record for which foundation facts can be judicially noticed. ${ }^{232}$

failed to show that the declarants wcre "conscious" that the testimony was not in their best interests), rev'd on other grounds sub nom. Matsushita Elec. Indus. Co. v. Zenith Radio Corp., $106 \mathrm{~S}$. Ct. 1348 (1986); Workman v. Cleveland-Cliffs Iron Co., 68 F.R.D. 562, 563 (N.D. Ohio 1975) (requiring a "more definite awareness" by the declarant of his adverse interests).

230. FED. R. Ev1D. 803(16). This exception represents a change from the common law, where the ancient documents rule was generally held to establish only authenticity without creating a hearsay exception. See Town of Ninety Six v. Southern Ry. Co., 267 F.2d 579, 583-84 (4th Cir. 1959); $5 \mathrm{~J}$. WIGMORE, supra note $2, \S 1573$, at $520-25$ (describing a narrow hearsay exception embracing certain recitals in ancient deeds).

Almost all documents admitted under this exception are newspaper articles or documents prepared for a business or public purpose. See, e.g., Compton v. Davis Oil Co., 607 F. Supp. 1221, 1228-29 (D. Wyo. 1985) (dceds and a death certificate as proof of marriage); United States v. Kairys, 600 F. Supp. 1254, 1258-60 (N.D. Ill. 1984) (admitting application for Lithuanian citizenship and other documents related to birth, parentage, and military service), aff'd, 782 F.2d 1374 (7th Cir.), cert. denied, 106 S. Ct. 2258 (1986); Ammons v. Dade City, Fla., 594 F. Supp. 1274, 1280 n.8 (M.D. Fla. 1984) (admitting newspaper articles about local public works projects that referred to "negro quarters" and subdivisions), aff'd, 783 F.2d 982 (11th Cir. 1986); Korematsu v. United States, 584 F. Supp. 1406, 1417-18 (N.D. Cal. 1984) (admitting internal governmental memoranda and letters).

Apparently the only case admitting personal papers from private custody is Bell v. Combined Registry Co., 536 F.2d 164, 166 (7th Cir.) (admitting private correspondence between author of a poem and a military doctor concerning the poem's distribution for copyright purposes), cert. denied, 429 U.S. 1001 (1976).

231. Courts have been strict in enforcing the authentication burden against proponents. See Dartez v. Fibreboard Corp., 765 F.2d 456, 464-65 (5th Cir. 1985) (intradepartment corporate minutes and memoranda were inadmissible due to failure to respond completely to "request for authentication"); Jeanneret v. Vichey, 693 F.2d 259, 264 \& n.7 (2d Cir. 1982) (1922 catalog from art show in Paris gallery inadmissible due to failure to authenticate).

232. See supra notes $138-43$ and accompanying text; cf. Korematsu, 584 F. Supp. at 1417-18 (admitting documents that were not judicially noticeable under a hearsay cxception). 
If neither process nor identification foundation witnesses are available, the fairness interests of the adversaries collide. The proponent seeks admission because she claims she needs the evidence, thus burdening the opponent with the risk of being unable to produce any foundation witness who knows any foundation facts about the declarant or the document. The opponent seeks exclusion, thus defending her own interest in having access to the proponent's proof sources.

The ancient document exception is an especially good example of how the categorical approach to admission systematically undermines the fairness interests of the opponent. The Advisory Cominittee uses a broad generalization about rehability ("age affords assurance that the writing antedates the present controversy") ${ }^{233}$ to justify preferring the interests of the proponent over the opponent. ${ }^{234}$ The operational approach to accuracy is preferable to relying on such generalizations. It is the trier's need for foundation facts to evaluate ancient documents that tips the balance to justify exclusion. The ancient documents exception should thus be elimmated unless revised to guarantee either that the proponent produces a witness to satisfy the basic or adjusted foundation fact standard, or that the circumstances underlying the document are sufficiently certain to meet a standard of judicial notice.

\section{Statements by Persons Associated with the Party Opponent}

Rule 801(d)(2) exempts from the definition of hearsay five categories of out-of-court statements connected to the party opponent against whom they are offered. ${ }^{235}$ The first three of these exemptions-statements and other conduct of the opponent under subsections (A) and (B), and statements made by the opponent's authorized agents under subsection (C)-require the proponent to identify the declarant. ${ }^{236}$ But fulfil-

233. FED. R. Evid. 803(16) advisory committee's note. Commentators have discussed other indications of the reliability of ancient documents. For example, authentication ensures that the statement was actually made, that mistransmission errors were minimized, and that the writing was more reliable than the declarant's memory of an event that happened years ago. 4 J. WEINSTEIN \& M. BERGER, supra note 12, if 803(16)[01], at 803-312. Critics of the exception have argued that "[t]he mere lapse of time does not afford any guarantee of veracity." Comment, Ancient Documents as an Exception to the Hearsay Rule, 33 YALE L.J. 412, 417 (1924).

234. The debate under the categorical approach is cast precisely in these terms. Advocates of the exception point to the "great need for such evidence when offered." Note, Recitals in Ancient Documents, 46 Iowa L. REv, 448, 453 (1961); see also 4 D. Louisell \& C. MuEller, Federal EVIDENCE $\S 464$, at 822 (1980) ("[i]t is the need factor . . which justifies a hearsay exception for ancient documents despite the absence of positive guarantees of trustworthiness."). See generally Wickes, Ancient Documents and Hearsay, 8 TEx. L. REv. 451 (1930).

235. Rule 801(d)(2) defines all five exemptions as admissions by a party opponent. Admission of these exempt categories-"the resuit of the adversary system"-is unrelated to the supposed circumstantial guarantees of trustworthiness that justify the exceptions under rules 803 and 804 . FED. R. Evid. 801(d)(2).

236. Statements by the party herself, admitted under rule $801(\mathrm{~d})(2)(\mathrm{A})$, require identification of 
ling the terms of subsections (A), (B), and (C) does not typically result in the production of witnesses knowledgeable about the basic process foundation for these statements, ${ }^{237}$ and thus does not automatically satisfy the basic foundation fact approach.

Nevertheless, admission of statements under (A), (B), and (C) is justified under the prior access principle. The opponent's control over the foundation circumstances when these statements were made, as in Example $9,{ }^{238}$ relieves the proponent of her burden to produce a foundation

the declarant as the real party in interest. FED. R. EvID. 801(d)(2)(A); see, e.g., Estate of Shafer v. Commissioner, 749 F.2d 1216, 1219-20 (6th Cir. 1984) (executor treated as a party in litigation involving the estate); Donovan v. Crisostomo, 689 F.2d 869, 876 (9th Cir. 1982) (statements by workers for whose benefit suit was brought held not to be admissions since Secretary of Labor was the real party in interest).

Under rule $801(\mathrm{~d})(2)(\mathrm{B})$, the opponent must adopt or in some manner manifest belief in the statement of another person. FED. R. Evid. 801(d)(2)(B); see, e.g., United States v. Hoosier, 542 F.2d 687, 688 (6th Cir. 1976) (silent acquiescence may constitute admission, depending on facts).

Statements of authorized agents, admitted under rule $801(\mathrm{~d})(2)(C)$, require proof of both the identity of the declarant and authorization by the opponent. FED. R. Evid. 801(d)(2)(C); see, e.g., B-W Acceptance Corp. v. Porter, 568 F.2d 1179, 1183 (5th Cir. 1978) (branch manager's testimony from previous trial admissible since opponent had authorized manager to testify).

237. Statements by a party under rule 801 (d)(2)(A) may be presented through a witness who merely overheard them. E.g., United States v. Pizarro, 756 F.2d 579, 579-86 (7th Cir.) (defendant's statement to a special agent), cert. denied, 471 U.S. 1139 (1985). Such statements are also frequently presented in documentary form. E.g., S. Leo Harmony v. Binks Mfg. Co., 597 F. Supp. 1014, 1022 (S.D.N.Y. 1984) (defendant's "barcharts" used in planning construction), aff'd, 762 F.2d 990 (2d Cir. 1985). Since the rule does not require a showing of personal knowledge, the trier often does not receive any facts about the declarant's perception opportunity or memory.

Proof under rule $801(\mathrm{~d})(2)(B)$ that the opponent has either adopted or manifested belief in a statement can require a knowledgeable foundation witness. See United States v. Moore, 522 F.2d 1068, 1076-77 (9th Cir. 1975), cert. denied, 423 U.S. 1049 (1976). The opponent can also adopt statements contained in documents and records through their documentary form. See, e.g., In Rc Japanese Elec. Prods. Antitrust Litig., 723 F.2d 238, 300-01 (3d Cir. 1983) (answers to interrogatories which cross-referenced documents held to be admissions), rev'd on other grounds sub nom. Matsushita Elec. Indus. Co. v. Zenith Radio Corp., 106 S. Ct. 1348 (1986); United States v. Morgan, 581 F.2d 933, 937-38 (D.C. Cir. 1978) (admission through sworn affidavit that particular statements were trustworthy).

Neither rule 801 (d)(2)(B) nor (C) requires a showing of the circumstances affecting the perception or sincerity of the declarant whose statement the opponent adopted. Wagstaff $v$. Protective Apparel Corp. of Am., 760 F.2d 1074, 1078 (10th Cir. 1985) (defendant's distribution of newspaper articles concerning its financial condition amounted to adopting the articles' contents); United States v. Buttram, 432 F. Supp. 1269 (W.D. Pa. 1977) (statements of authorized agent admissible despite finding that agent was legally insane at the time the statements were made), aff'd. 568 F.2d 770 (3d Cir.), cert. denied, 435 U.S. 995 (1978).

238. See supra text accompanying notes 134-35. The opponent's control over her own statements gives her access to relevant foundation facts and justifies admission under rule 801(d)(2)(A). Cf. United States v. Pizarro, 756 F.2d 579, 584 (7th Cir.) (defendant's statement to federal agent after his first trial, "Hey man, can I have my dope back?," admitted in second trial. Defendant's objection under rnle 403 was rejected because jury could assess weight "in light of the fact that [defendant] argued that the statement was only a joke"), cert. denied, 471 U.S. 1139 (1985).

The finding under subsection (B) that the opponent had an opportunity to hear and understand the declarant's statement establishes the opponent's prior access and her control over her manifestation of belief. See United States v. Carter, 760 F.2d 1568, 1579.80 (11th Cir. 1985). Similarly, under subsection (C), the finding that the opponent authorized her agent to make the 
witness knowledgeable about these circumstances. The opponent can choose whether to produce foundation witnesses to explain or impeach the declarants' statements. If the opponent fails to do so, the trier can use this information to make specific inferences about the declarants' reliability.

The remaining two categorical exemptions--statements of the opponent's agents or servants (hereinafter employees), admitted under subsection (D), and statements of the opponent's co-conspirators, admitted under subsection (E)-do not require proof that the opponent controlled or authorized the making of the statement. Instead, the proponent must prove only that an agency, employment, or conspiratorial relationship existed between the declarant and the opponent, and that the declarant's statement was temporally and substantively connected to that relationship. ${ }^{239}$ Although this may elicit some facts about the declarant's identity and the circumstances in which the declarant made the hearsay statement, ${ }^{240}$ it will not reveal facts about the declarant's perception opportunity. ${ }^{241}$ Courts even admit statements without any showing that the declarant has firsthand knowledge of the asserted facts. ${ }^{242}$

Admitting employee and co-conspirator statements that constitute illegal activities expands the substantive legal liability of employers and alleged conspirators to include the acts of their agents. ${ }^{243}$ Admitting

statement is critical to this control theory of prior access. See United States v. McKeon, 738 F.2d 26, 33 (2d Cir. 1984) (statements made to jury by opponent's attorney admitted because court noted that the opponent himself had participated in this choice of strategy); see also cases cited supra note 236.

239. FED. R. EvID. 801(d)(2)(D)-(E).

240. Rule 801 (d)(2)(D) requires proof that the declarant is an agent or servant and that the opponent is either a principal or employer. If proof of agency must be independent of the agent's statement, then the proponent will typically produce a foundation witness. See, e.g., Mackey v. Burke, 751 F.2d 322, 325-26 (10th Cir. 1984). Under rule 801(d)(2)(E), most circuits require proof by a preponderance of the evidence, from sources independent of the co-conspirator's statement, not only that there is a conspiracy and that the declarant is a co-conspirator but, most importantly, that the opponent is also a co-conspirator. The conflict in the circuits regarding criminal cases is described in Arnott v. United States, 464 U.S. 948 (1983) (White, J. dissenting from denial of certiorari). For a civil conspiracy case, see Park v. El Paso Bd. of Realtors, 764 F.2d 1053 (5th Cir. 1985) (trial court must make a finding that preponderance of the evidence established the existence of a conspiracy involving both the declarant and the opponent), cert. denied, $106 \mathrm{~S}$. Ct. 884 (1986).

241. Although statements by an employee must be made during the employment relationship and must concern a "matter within the scope of his agency or employment," nothing mandates that the statement must also concern something perceived in the course of 4 employment, that is, while on the job.

242. See, e.g., MCI Communications Corp. v. American Tel. \& Tel. Co., 708 F.2d 1081, 1143 (7th Cir.) (admitting internal study conducted by opponent's employees), cert. denied, 464 U.S. 891 (1983); United States v. Ammar, 714 F.2d 238, 254 (3d Cir.) (no showing of the declarant's firsthand knowledge required for rule 803 and 804 exceptions), cert. denied, 464 U.S. 936 (1983).

243. In these cases, the reach of subsection (D) is properly a matter for the substantive law of agency. See Lloyd v. Professional Realty Servs., 734 F.2d 1428, 1433 \& n. 14 (11th Cir. 1984) (offers made by declarant cannot bind opponent unless "some authority" is shown), cert. denied, 469 U.S. 1159 (1985); Carl Wagner \& Sons v. Appendagez, Inc., 485 F. Supp. 762, $767-70$ (S.D.N.Y. 1980) 
statements of belief makes opponents accountable for the agents' beliefs, so long as those beliefs relate to the shared enterprise. ${ }^{244}$ If the opponent has control over the agent, and thereby the agent's statements, the opponent has prior access to the foundation facts affecting these declarant similar to the access an opponent has to facts known to herself and her authorized agents. Admission could then be justified under the prior access principle on the same basis as Example 9. ${ }^{245}$ However, employee and co-conspirator relationships are broadly defined by subsections (D) and $(E)$ to mclude opponents who do not necessarily enjoy such direct control. ${ }^{246}$

If the prior access principle does not extend to these relationships, the proponent of statements made by employees and co-conspirators should be required to produce the basic process foundation. Subsections (D) and (E) already require production of a witness to establish that the employee or co-conspirator statement was made during the employment relationship or in furtherance of the conspiracy. Applying the foundation fact approach, this requirement should be extended to insure that this same witness know about the circumstances affecting the making of the statement. The proponent would then have to produce a witness knowledgeable about the declarant's perception opportunity. If this type of witness is unavailable, under the adjusted foundation ${ }^{247}$ an identification witness could be substituted so long as the statement established the declarant's opportunity for firsthand knowledge. Production of an iden-

(statements of employees regarding illegal price-fixing policy admissible if made with apparent authority). Similarly, the legal effect of co-conspirators' statements that constitute illegal acts is a matter for substantive conspiracy principles. $4 \mathrm{~J}$. WEINSTEIN \& M. BERGER, supra note 12, Il 801(d)(2)(E)[01], at 801-232. Courts could admit these kinds of statements as nonhearsay, leaving the agency or conspiracy question to be decided separately. Id., 1801 (d)(2)(E)[01], at 801-243, 801247.

244. This restriction is imposed by the timing and subject matter conditions of rule 801 (d)(2)(D) and (E). See Hill v. Spiegel, Inc., 708 F.2d 233, 236-37 (6th Cir. 1983) (statements amounting to confessions of age discrimination excluded because discharge not within scope of declarants' responsibility). Co-conspirator statements implicating the opponent must be made before the termination of the conspiracy, United States v. Floyd, 555 F.2d 45, 48 (2d Cir.), cert. denied, 434 U.S. 851 (1977), and must further the conspiracy's illegal purpose. Wong Sun v. U.S., 371 U.S. 471 (1963) (refusing to broaden the narrow hearsay exception that admits statements made in furtherance of a conspiracy).

245. See supra text accompanying notes 134-36.

246. See, e.g., United States v. Young, 736 F.2d 565, 568-69 (10th Cir. 1983) (statement of one employee, a corporate accountant, admitted against another employee, a corporate vice-president), rev'd on other grounds, 470 U.S. 1 (1985); Corrigan v. United States, 609 F. Supp. 720, 727 n.3 (E.D. Va. 1985) (statement of bartender employed at noncommissioned officers' club admitted in suit against United States government), rev'd on other grounds, 815 F.2d 954 (4th Cir. 1987). In sucl cases, one could justify admitting the beliefs of employees and co-conspirators by policies, extrinsic to hearsay values, that extend the responsibilities of certain kinds of parties. Substantive law values beyond the scope of general hearsay policy, therefore, may justify admitting the beliefs of employees and co-conspirators. See supra note 88.

247. See supra text accompanying notes 123-31. 
tification witness would not be difficult. The proponent is already required to identify the declarant as an employee or as a co-conspirator, presumably through a witness who knows the declarant. ${ }^{248}$

\section{Former Testimony}

Introducing a hearsay statement under rule 804(b)(1)'s definition of former testimony does not require production of a knowledgeable foundation witness because the testimony is usually presented in a properly authenticated transcript. ${ }^{249}$ This frustrates the functions of both the trier and the opponent. However, rule 804(b)(1) requires that the opponent against whom the declarant's former testimony is now being offered (or, in a civil case, a predecessor in interest to the opponent) "had an opportunity and similar motive to develop the testimony by direct, cross, or redirect examination."250 The opponent's prior access to the declarant as a source of foundation facts may be sufficient to justify admission under the prior access principle, as in Example 8. ${ }^{251}$ These facts will also be in the transcript, available for the opponent's use.

If the opponent did not take advantage of her prior access to adequately examme the declarant, she need not get a second chance. ${ }^{252}$ It would be unfair to allow her to burden the proponent at trial, when the fairness values underlying this burden were already satisfied at the hearing or deposition, as in Example 8. To insure that the fairness values were satisfied, courts should rigorously apply the terms of rule 804(b)(1) to require that the opponent had a genuine opportunity to examine the declarant, ${ }^{253}$ and a similar motive to conduct a thorough exainination. ${ }^{254}$

248. The identity of a declarant as a co-conspirator is usually established by witnesses who are former co-conspirators themselves. See, e.g., United States v. Ammar, 714 F.2d 238, 249-51 (3d Cir.) (status of declarants as co-conspirators established by testimony of two unindicted coconspirators and two co-conspirators who pled guilty), cert. denied, 464 U.S. 936 (1983). Government agents who have infiltrated the conspiracy may also perform this function. The foundation witnesses must be at least fairly knowledgeable about the activities of the declarant, since mere association with those who have conspired is inadequate to constitute conspiracy by the declarant. Id. at 250-51.

249. FED. R. Evid. 804(b)(1).

250. Id.

251. See supra text accompanying notes 132-34.

252. Assuming proper notice, opponent's absence from the proceeding is treated as an issue of "meaningful waiver." United States v. Feldman, 761 F.2d 380, 385 \& n.5 (7th Cir. 1985).

253. See, e.g., United States v. Harenberg, 732 F.2d 1507, 1515-16 (10th Cir. 1984) (no opportunity exists if the current opponent was not a party to the prior proceeding); In re Paducah Towing Co., 692 F.2d 412, 418-19 (6th Cir. 1982) (no opportunity if the party was constrained in cross-examination by the absence of a lawyer and the skills necessary to conduct a successful interrogation); see also United States v. Feldman, 761 F.2d 380, 385 (7th Cir. 1985) ("[m]ere "naked opportunity' to cross-examine is not enough; there must also be a perceived 'real need or incentive to thoroughly cross-examine" " at the time of the prior proceeding) (quoting United States v. Franklin, 235 F. Supp. 338, 341 (D.D.C. 1964)).

254. To determine whether the opponent had a similar motive to cross-examine the declarant at 
The trier will evaluate the declarant with the foundation facts that are contained in the prior testimony, ${ }^{255}$ and with knowledge that the opponent failed to examine the declarant.

These arguments do not apply, however, if the opponent herself did not have prior access to the declarant. If another person, even a predecessor in interest, was involved in the former proceeding, the current opponent would never have had access to the declarant as a source of foundation facts. The current opponent's behavior is, therefore, not relevant in evaluating the statement's reliability. Judicial decisions broadening the concept of "predecessor in interest" under rule 804(b)(1) to include any party who had a similar motive to examine the declarant at the former proceeding undermine the opponent's fairness interest and the jury's ability to evaluate..$^{256}$ Admission in such cases can only be justified by values extrinsic to hearsay policy. Under the foundation fact approach, admission is not justified when the opponent herself (or her authorized agent) had no prior access to the declarant, unless the proponent can satisfy the adjusted foundation with an identification witness. ${ }^{257}$

the prior proceeding, "a court must evaluate not only the similarity of the issues, but also the purpose for which the testimony is given." Feldman, $761 \mathrm{~F} .2 \mathrm{~d}$ at 385 (where defendants did not contest the civil case but vigorously defended the criminal aetion, court noted that strategies may differ for civil and criminal trials); see also DeLuryea v. Winthrop Laboratories, 697 F.2d 222, 22627 (8th Cir. 1983) (identity of misconduct issues in worker's compensation proceeding and suit against drug manufacturer gave plaintiff similar motive to cross-examine treating psychiatrist); United State v. Atkins, 618 F.2d 366, 373 (5th Cir. 1980) (government had no motive to carefully cross-examine witness at a hearing about his identification of another cocaine source since the hearing did not concern the witness).

255. Some foundation facts are contained in the declarant's former testimony itself. At least the circumstances that affected the declarant's making of her statement are known: the declaration was made under oath, in a public setting, and subject to cross-examination. Moreover, her testimony would probably contain an explanation of her perception opportunity. It could also contain more information about the specific circumstances affecting her perception and memory of the events. But the terms of rule $804(\mathrm{~b})(1)$ do not require such extensive development of process foundation testimony.

256. Under the broader interpretations of the term "predecessor in interest" in rule 804(b)(1), similar motive is essentially the only requirement. See, e.g., Clay v. Johns-Manville Sales Corp., 722 F.2d 1289, 1295 (6th Cir. 1983), cert. denied, 467 U.S. 1253 (1984); Lloyd v. American Export Lines, 580 F.2d 1179, 1187 (3d Cir.), cert. denied, 439 U.S. 969 (1978).

[Both of these cases] ignore the fact that [in drafting rule 804(b)(1)] Congress changed the rule and rejected the idea that one litigant's prior opportunity to examine a witness is enough to warrant admission of the witness' former testimony against a second litigant, as long as the two litigants had similar motives and interests in examining the witness.

S. SAltZBurg \& K. REDDEN, supra note 24 , at 954.

The above cases seize on the fortuity of examination by a party in a prior case and equate that party to the opponent in the later case. These holdings demonstrate a preference for the proponent's interest in wider access to proof over the opponent's fairness interest in access to the deciarant. This preference is based on values extrinsic to hearsay policy, such as society's interest in law enforcement. Lloyd, 580 F.2d at 1186 ("the basic interest advanced by both was that of determining culpability and, if appropriate, exacting a penalty for the same condemned behavior"). It also, however, tilts the balance of fairness against defendants. See supra text accompanying notes 93-99 and 252-55.

257. See supra text accompanying notes 123-31. Regardless of the opponent's prior access to 


\section{Hearsay Generated by Multiple Declarants}

The remaining categorical exceptions to be discussed admit hearsay statements generated by multiple declarants. The original declarant(s) who perceived the relevant event and the reporting declarant who made the final statement about it are different people. To evaluate the reliability of such hearsay statements, the trier must evaluate the testimonial qualities of all declarants. Under the foundation fact approach, the proponent should produce foundation witnesses knowledgeable about (1) the original declarant's process of perceiving the relevant event, remembering it, and making a statement about it to the reporting declarant; and (2) the reporting declarant's process of perceiving what she is told, remembering it, and making her own statements about it, usually in writing, as in Example 4. ${ }^{258}$

The categorical exceptions to be discussed-including public records, public compilations of data, reputations, and judgments-do not require the proponent to produce so complete a process foundation. They do not require production of a witness knowledgeable about the original perceiving declarant. Without such a witness, the trier must rely on the evaluation made explicitly or implicitly by the reporting declarant. The reporting declarant's beliefs about reliability displace the trier's own general knowledge and experience, and the opponent is deprived of trial access to sources of foundation facts. This threatens the values of operational accuracy, independence, and fairness. However, in some instances the principles of expertise and judicial notice justify admission under the foundation fact approach.

\section{Public Records}

The terms of the exception for public records in rule 803(8) do not require a custodian or other qualified witness to present the record at trial. The record can be admitted on the basis of facts contained in the report itself that pertain to how it was produced and to the qualifications of the reporting declarants. ${ }^{259}$ Without the production of a knowledgeable foundation witness, the values underlying the foundation fact approach are harmed. The foundation needed for the trier's evaluation may be incomplete; the opponent has no live source of foundation facts to cross-examine. The 803(8) exception should, therefore, be revised to require a qualified witness to present the record, in terms similar to the

the declarant, former testimony may be admissible if it satisfies the adjusted foundation and if all process foundation witnesses, including the declarant, are unavailable. The former testimony itself must also contain process facts and the proponent must produce an identification witness.

258. See supra text accompanying notes 57-58.

259. FED. R. EvID. 803(8). 
exception for business records. ${ }^{260}$

Public reports admitted under rule $803(8)(C)$ containing evaluative factual findings present particular problems for foundation fact policy. These findings, which must be based on an investigation, often rely on the perceptions of many original perceiving declarants. ${ }^{261}$ The investigative declarant evaluates these perceiving declarants in arriving at a finding, often in the form of an opinion. ${ }^{262}$ The declarant's expertise justifies admission in these cases, as in Example $11,{ }^{263}$ but the need for a foundation witness is particularly acute, as in Example 12. ${ }^{264}$ Without a foundation witness, the trier will be deprived of information about the quality of the investigation and the expertise of the investigating declarant, and the opponent will have no trial access to a source of facts.

Rule 803(8) provides that public reports may be excluded for lack of trustworthiness. ${ }^{265}$ The exclusionary clause is used by judges to require

260. Records of activity of a public agency admitted under rule $803(8)$ (A) are analogous to private business records and would also be admissible under 803(6). Public records are admitted under rule $803(8)(B)$ only if the matters were observed and the report was made pursuant to a duty imposed by law. Where courts have analyzed the requirements of $803(8)$ (B) in depth, they have imposed this twofold duty similarly to the foundation requirements for a business record. See Wetherill v. University of Chicago, 518 F. Supp. 1387, 1390 (N.D. 1ll. 1981). Records admitted under rule $803(8)$ (C) present special problems, discussed infra text accompanying notes 261-79.

261. Under rule $803(8)(C)$, the investigator need not have personal, firsthand knowledge of the events on which the report's findings are based. See Robbins v. Whelan, 653 F.2d 47, 52 (1st Cir.) (reporting agency need only have firsthand knowledge of the investigation, not of the underlying facts on which it bases its findings), cert. denied, 454 U.S. 1123 (1981); Fraley v. Rockwell Int'l Corp., 470 F. Supp. 1264, 1266-67 (S.D. Ohio 1979) (firsthand knowledge of witnesses to airplane accident is sufficient to render accident report admissible despite investigator's lack of such knowledge); 4 D. Louisell \& C. MUELlER, supra note 234, §455, at 734-35 (discussing investigative reports); 4 J. WEINSTEIN \& M. BERGER, supra note 12, at ๆ 803(8)[03]. But see Miller v. Caterpillar Tractor Co., 697 F.2d 141, 144 (6th Cir. 1983) (reports inadmissible where authors of accident and engineering reports relied on others' information rather than on firsthand knowledge of reported events).

The original sources of knowledge vary considerably. See, e.g., Roth v. Black \& Decker, U.S., 1nc., 737 F.2d 779, 783 (8th Cir. 1984) (account of consumer injuries contained in United States Consumer Products Safety Commission report); Kehm v. Proctor \& Gamble Mfg., 724 F.2d 613, $617-18$ (8th Cir. 1983) (statements of physicians, patients, and parents of Toxic Shock Syndrome victims reported in Center for Disease Control document); Robbins, 653 F.2d at 51 (automobile manufacturers' statements appeared in Department of Transportation report on automobile stopping distances); Cohen v. General Motors Corp., 534 F. Supp. 509, 510-11 (W.D. Mo. 1982) (consumers' and a Nader organization's complaints about sticky power steering documented in National Highway Traffic Safety Administration records); Fraley, 470 F. Supp. at 1265 (military and nonmilitary sources contained in Naval Facility report).

262. Kehm, 724 F.2d at 618 (admitting opinions of doctors, state health officials, and Center for Disease Control scientists as expressed in CDC studies); Baker v. Elcona Homes Corp., 588 F.2d 551, 554-56 (6th Cir. 1978) (admitting opinion of 28-year veteran of state Highway Patrol through his police accident report), cert. denied, 441 U.S. 933 (1979); Walker v. Fairchild 1ndus., 554 F. Supp. 650, 653-54 (D. Nev. 1982) (admitting opinions of experienced pilots and U.S. Air Force Aeronautical System Labs as contained in U.S.A.F. Aircraft Accident Investigation report).

263. See supra text accompanying notes 143-45.

264. See supra text accompanying notes $145-47$.

265. FED. R. EVID. 803(8). 
that information be produced about the qualifications of the investigator, the nature of investigation, and the investigator's evaluation of the underlying sources of knowledge. ${ }^{266}$ The Advisory Committee's note to rule 803(8) specifies four factors relevant to the trustworthiness of an investigative report. ${ }^{267}$ All of the factors-timeliness of the investigation, the special skill or experience of the official, whether a hearing was held and the level at which it was conducted, and possible motivation problemsare foundation facts about the expertise of the reporting declarant.

In practice, the presence in court of a knowledgeable foundation witness to present these detailed facts is often crucial to the report's admission. ${ }^{268}$ Judges should use (and a few acknowledge that they do) the trustworthiness clause to test the qualifications of the reporting declarant and to require production of a foundation witness. This interpretation of the terms of rule 803(8) produces a source of foundation facts, providing access to the opponent and enabling the trier to evaluate the expertise in the report. ${ }^{269}$

266. Some courts have explicitly analogized public reports to the rules regulating the admission of expert testimony. See Melville v. American Home Assurance Co., 443 F. Supp. 1064, 1114-15 (E.D. Pa. 1977) (harmonizes 803(8)(C) with Federal Rules of Evidence 702 and 705: both Rules 702 and $803(8)(C)$ require qualifications for the expert/agency to express its opinions; while Rules 705 and $803(8)(C)$ focus on the foundation for the opinions), rev'd on other grounds, 584 F.2d 1306 (3d Cir. 1978).

Courts exclude reports authored by investigators not expert in the relevant field of inquiry. See, e.g., Miller v. Caterpillar Tractor Co., 697 F.2d 141, 144 (6th Cir. 1983) (miniug engineer unqualified to render opinion as to mechanical failure); Wetherill, $518 \mathrm{~F}$. Supp. at 1388-90 (consultants to HEW task force that authorized report were nonprofessionals); Fraley, $470 \mathrm{~F}$. Supp. at 1267 (investigator lacked necessary expertise in complex field). But see Walker v. Fairchild Indus., 554 F. Supp. 650, 654-55 (D. Nev. 1982) (objections as to qualifications of investigators go to weight rather than admissibility). In many product liability actions which rely on public reports, courts assume the expertise of the reporting agency. See, e.g., Ellis v. International Playtex, Inc., 745 F.2d 292, 301 (4th Cir. 1984) (Center for Disease Control and state health departments both noted as highly skilled in the study of epidemiology).

Courts can also examine the quality of the investigation by scrutinizing its methodology. See, e.g., Ellis, 745 F.2d at 301-03. Where the court determines that the original sources of information were not reasonably reliable, it excludes the report. See, e.g., Miller, 697 F.2d at 144 (refusing to admit accident and enginecring reports based on information from others and on hearsay statements); John McShain, Inc. v. Cessna Aircraft Co., 563 F.2d 632, 636 (3d Cir. 1977) (statements of pilots and other witnesses to airplane accidents had to be inadmissible hearsay); Wetherill, 518 F. Supp. at 1390 n.4 (not admitting a HEW task force report because it was based on evidence from numerous informal, unpublished and nonexpert sources).

267. FED. R. Evid. 803(8)(C) advisory committee's note.

268. See, e.g., Kehm v. Proctor \& Gamble Mfg., 724 F.2d 613, 617 (8th Cir. 1983) (former member of Center for Disease Control task force testified about studies); Baker v. Elcona Homes Corp., 588 F.2d 551, 554 (6th Cir. 1978) (investigator who compiled accident report testified), cert. denied, 441 U.S. 933 (1979); Givens v. Lederle, 556 F.2d 1341, 1346 (5th Cir. 1977) (Center for Disease Control physician who edited polio reports appeared as a foundation witness).

269. In Ellis, 745 F.2d at 303-04, the court explicitly relied on the jury's ability to evaluate data contained in investigative reports, in a manner analogous to the jury's increasing role in evaluating the testimony of expert witnesses. The court states that concern about the methodology of a public report could be reflected in the weight accorded the report and not its admissibility: 


\section{Public Compilations of Data}

Five of the Federal Rules' exceptions concern documents generated by public record keeping. These exceptions admit records of vital statistics, ${ }^{270}$ records of personal or family history kept by religious organizations, ${ }^{271}$ certificates of the performance of ceremonial or sacramental acts, ${ }^{272}$ recorded versions of documents affecting an interest in property, ${ }^{273}$ and market reports and other commercial data compilations. ${ }^{274}$ These public documents are always produced by multiple declarantsthe original perceiving declarants who provide information and the reporting declarants who have a public, religious, or professional duty to record the information and prepare the compilation.

Fulfilling the terms of each exception requires identification of the reporting declarant and the nature of the document produced. If these necessary facts are contained in the documents themselves, the proponent need not produce any knowledgeable foundation witness. No custodian or other qualified witness is explicitly required by any of these exceptions. Thus, the trier and the opponent have no access to information about how the duty of a recording declarant affects her perceiving, remembering, and recording of relevant events, or about how the original perceiving declarants furnished the relevant information.

However, many of these compilations are routinely kept bureaucratic records of events and occurrences. The original perceiving declarants are private sources acting under public or private duties to provide information. ${ }^{275}$ Making the record does not require the reporting declar-

\footnotetext{
Allowing the jury to evaluate the reports after careful cross-examination and the presentation of expert testimony ... permits admission without sacrificing scrutiny. ... In an era when scientific data is playing an increasingly important role at trial ... there is no reason not to let the jury see and evaluate the same data that the experts-whether they be Id. doctors or other specialists-are relying on to reach their conclusions.

This analysis is based on providing the trier and the opponent with a knowledgeable source of foundation facts. It distinguishes administrative findings from records of trial judgments where no analogous foundation witness could be presented. See supra note 257 . The availability of such a witness is a sound basis upon which to distinguish the broad admissibility of administrative findings. Cf. Motumura, supra note 89 , at $986-87$ ("Neither case law nor commentary adequately explains why administrative findings should enjoy this greater range of subsequent effect.").

270. FED. R. Ev1D. 803(9).

271. FED. R. Evid. 803(11).

272. FED. R. Ev1D. 803(12).

273. FED. R. EVID. 803(14).

274. FED. R. EVID. 803(17).

275. The original declarants who contribute to the public and religious records defined by Rules 803(9), (11) and (12) have a legal or religious obligation to make the record. The original declarants who contribute to the records defined by Rules 803 (14) and (17) have a business duty to create the record. These duties are circumstances that affect these declarants' perception, memory, and report of the relevant events. Where the sources of information are not generated by these private duties, less is known about the circumstances affecting them. Compare Hall v. Commissioner, 729 F.2d 632, 634-35 (9th Cir. 1984) (without proper foundation, statement of contributions to church do not
} 
ants to do investigative factfinding, ${ }^{276}$ nor to apply expertise to evaluate the reliability of the original declarants.

Courts may, therefore, take judicial notice of the process foundation for these records, satisfying the basic standard of the foundation fact approach as in Example 10. ${ }^{277}$ The proponent is still obligated to provide proof about the foundation in the judicial notice inquiry, but not at trial. ${ }^{278}$ If the opponent shows special circumstances or deviations from the routine process of production, she may defeat judicial notice. Courts can sometimes extend judicial notice to the information contained in the records where the rigorous standard of certainty is satisfied. ${ }^{279}$ Otherwise, the court presents the judicially noticed facts to the trier to evaluate the reliability of the records for itself.

\section{Reputations}

The Federal Rules limit the admission of reputation to prove the facts related to three topics: (1) reputation concerning personal or family history; $;^{280}$ (2) reputation concerning boundaries or general history; ${ }^{281}$ and (3) reputation of a person's character. ${ }^{282}$ Reputations are created by multiple declarants. The original perceiving declarants have firsthand knowledge of the reputed events, and the reporting declarants constitute the group within which the reputation persists. ${ }^{283}$ The proponent must

qualify as religious records under rule 803(11)) with McDonald v. Johnson \& Johnson, 537 F. Supp. 1282, 1355-56 (D. Minn. 1982) (trade report for estimating number of patients with chronic back paiu admissible under rule 803(17)), aff'd in part and vacated in part on other grounds, $722 \mathrm{~F} .2 \mathrm{~d}$ 1370 (8th Cir. 1983).

276. See, e.g., White Indus. v. Cessna Aircraft Co., 611 F. Supp. 1049, 1068-69 (W.D. Mo. 1985) (10-K forms and prospectus excluded because they did not contain "straightforward objective facts," but required "a subjective analysis of other facts"); see also $4 \mathrm{~J}$. WE1NSTEIN \& M. BERGER, supra note 12, f 803(6)[01], at 803-175. But see, Weiner v. Metropolitan Life Ins. Co., 416 F. Supp. 551, 558 (E.D. Pa. 1976) (statements in a dcath certificate admitted as prima facie evidence of the cause of death under rule 803(9) and state statute) (criticized in S. SALTZBURG \& K. REDDEN, supra note 24 , at 893 ).

277. See supra text accompanying notes 138-43.

278. See supra note 143 .

279. See cases cited supra notes $275-76$ (providing analogies to the kinds of process facts underlying the production of records under Rules 803(9), (11), (12), (14) and (17)).

280. FED. R. EVID. 803(19).

281. FED. R. EVID. 803(20).

282. FED. R. EVID. 803(21).

283. The relevant group under rules $803(19)$ and $803(21)$, the exceptions for personal and family history and personal character, may consist of family members, associates, or members of the community at large. $4 \mathrm{~J}$. WEINSTEIN \& M. BERGER, supra note 12, $\uparrow 803(19)[01]$, at 803-338 to $-339,803-347$. Courts have expanded the term "community" to include any substantial community of people among whom the person or information testified about is well known. See, e.g., United States v. Oliver, 492 F.2d 943, 945-46 (8th Cir. 1974) (crime victim's reputation among dormitory roommates), cert. denied, 424 U.S. 973 (1976).

The relevant group under rule 803 (20) appears to be limited to the community at large. See $4 \mathrm{~J}$. WEINSTEIN \& M. BERGER, supra note 12, ff 803(20)[01], at 803-343 to -345. 
produce a foundation witness who knows the group, ${ }^{284}$ and who is therefore knowledgeable about the circumstances affecting how the group perceives, remembers, and makes statements about the reputation.

If the foundation witness does not know the original perceiving declarants, the trier will have no information about the original declarants' perception opportunity. The trier cannot independently evaluate the original declarants. Thus, the reporting declarant's evaluation effectively displaces the trier's own evaluation. This undermines the hearsay values of operational accuracy and independence. If the reporting declarant has expertise that is offered to the opponent and to the trier through the foundation witness at trial, then foundation fact policy is satisfied, as in Example 11. ${ }^{285}$ However, it is questionable whether community groups have special knowledge or experience that qualifies as expertise in evaluating the sources and subject matter of reputations. Reputations should be admitted only if standards can be developed to distinguish those groups that do have special evaluation skills so that the risk of displacing the trier's evaluation is justified. ${ }^{286}$ The loss of reputation evidence under the foundation fact approach can be tolerated, since the main function of such evidence, that of proving character, is now usually performed by opinion evidence.

\section{Judgments}

Judgments are statements about disputed facts embedded within verdicts or judicial opinions. If made by the jury or judge after a trial process, judgments contain two levels of declarants. ${ }^{287}$ The original perceiving declarants are the witnesses and hearsay declarants who were presented at the previous trial. The reporting declarants are the previous jury members or judge who rendered the verdict or opinion. Rules $803(22)$ and $803(23)$ admit only felony convictions, and civil or criminal judgments establishing facts of personal, family, or general history or land boundaries, as evidence of those facts upon which the judgment was

284. See, e.g., United States v. Ocampo, 650 F.2d 421, 428 (2d Cir. 1981) (testimony of Drug Enforcement Administration agent as to defendant's "street name" was held inadmissible under rule $803(19)$ because it was based on information from documents and an unidentified informant).

285. See supra text accompanying notes 143-44.

286. Courts that impose restrictions on the nature of the relevant group may be unwittingly requiring some concept of special skill. Ute Indian Tribe v. State, 521 F. Supp. 1072, 1149-50 (D. Utah 1981) (reputation in non-Indian community as to boundaries of Indian reservation inadmissible under 803(20)), aff'd in part and rev'd in part on other grounds, 716 F.2d 1298 (10th Cir. 1983), cert. denied, 107 S.Ct. 596 (1986). The skill should reflect the nature of the group or community as it specifically relates to the topic of the reputation.

287. In contrast, judgments produced by a criminal defendant's own guilty plea do not involve the testimonial reliability of two levels of declarants. They are admissions of a party opponent under rule $801(\mathrm{~d})(2)(\mathrm{A})$ or statements against interest under rule $804(\mathrm{~b})(3)$. See supra text accompanying notes 220-28 and 235-38. 
based. ${ }^{288}$ These exceptions do not require the proponent to produce any witness knowledgeable about either group of declarants, since most judginents are proved through self-authenticating or stipulated documents. ${ }^{289}$

Under the foundation fact approach, the process standard of admission is necessarily unsatisfied. The current trier of fact is presented with no foundation facts to evaluate the reliability of either the original perceiving declarants or the reporting declarants. The opponent has no access at trial to any foundation witnesses.

The only basis upon which the current trier can give value to a judgment is to rely on the previous trier's evaluation of the original perceiving declarants. ${ }^{290}$ This satisfies foundation fact policy if the reporting declarant, here the previous trier, has expertise in investigating and evaluating the original declarants as sources of knowledge, as in Example 11..$^{291}$ The previous triers, juries or judges, are not expert, but they do use the saine background knowledge and experience that ultinately evaluates evidence anyway. Their generahzations are indistinguishable from those of the current trier; their evaluations, therefore, do not displace those of the current trier in violation of foundation fact policy. The current trier and the opponent know about the circumstances that affected the previous trier without needing any foundation witness to tell them. The trial judge, acting as trier of fact, already has special knowledge and experience to evaluate the reliability of the previous trier of fact. If the current trier is a jury, jury members have circumstantial evidence from their own experience about how the former jury was acting when it perceived and

288. FED. R. EvID. 803(22), 803(23). Rule 803(23) admits judgments if they are based on the same categories of facts defined in the reputation exceptions of rules 803(19) and (20).

Statutes and judicial decisions have held judgments admissible as evidence to promote specific enforcement policies of the underlying substantive law. See Motumura, supra note 89, at 991-1002. Statutes and judicial decisions also give evidentiary effect to judgments in the substantive areas of antitrust, employment discrimination, and patent litigation.

289. The proponent must present evidence of the judgment itself or obtain a stipulation from the opponent; notations on a police "rap sheet" that purport to record criminal convictions are insufficient. United States v. Perlmuter, 693 F.2d 1290, 1294 (9th Cir. 1982). Foreign judgments are tested for authenticity and acceptability. See Lloyd v. American Export Lines, 580 F.2d 1179, 118990 (3d Cir.) ("whether the foreign proceedings accord with civilized jurisprudence, and are stated in a clear and formal record"); cert. denied, 439 U.S. 969 (1978).

290. Note, Judgment of Conviction-Effect in a Civil Case as Res Judicata or as Evidence, 27 ILL. L. REv. 195, 198 (1982) ("The present jury, if it really considers the matter, must either blindly accept the conclusion of the first jury or ignore it because there is no rational alternative."). The advisory committee's note to rule $803(22)$ concedes that the current trier is unable to evaluate the reliability of the judgment itself. The Advisory Committee justifies admission by shifting the burden of explanation to the defendant: "While this may leave a jury with the evidence of conviction but without means to evaluate it, . . . it seems safe to assume that the jury will give it substantial effect unless defendant offers a satisfactory explanation ...." FED. R. EviD. 803(22) advisory committee's note.

291. See supra text accompanying notes 143-44. 
remembered the trial evidence and then communicated its beliefs about the evidence by its verdict.

However, the absence of a foundation witness denies the opponent trial access to a source of foundation facts about the original perceiving declarants presented at the previous trial. The opponent may offer her own witnesses to testify about the reliability of these declarants, ${ }^{292}$ but this is unfair under foundation fact policy ${ }^{293}$ unless the principle of prior access is satisfied, as in Example 8. ${ }^{294}$ If the judgment was rendered either for or against the opponent, or at a proceeding in which she at least participated, she had prior access to the underlying declarants. On the other hand, if the case was unrelated to the opponent, she had no prior access. Only values extrinsic to foundation fact policy, such as societal interests in upholding respect for the force of judgments, could justify admission in this case. ${ }^{295}$

292. The opponent of the judgment may "offer such explanation or mitigating circumstances with respect to the proceedings or judgment as may be deemed admissible by the district court in this connection." Lloyd, 580 F.2d at 1190 . While Lloyd involved the consideration of a prior foreign judgment, no analytical reason exists for limiting explanations of prior judgments to that situation. Indeed, commentators assume that any judgment may be attacked in this fashion. See D. LouISELL \& C. MUeller, supra note 234, at 910 \& n.38; 4 J. WEINSTEIN \& M. BERGER, supra note 12, at 803-351. Apparently, however, no reported cases under the Federal Rules specifically address the question. The pendency of an appeal or any other post-trial motion may also be presented to the jury. D. Louisell \& C. MUELLER, supra note 234, at 894-95 \& n.1.

293. Motomura argues to the contrary. He states that although collateral estoppel is grounded on fairness due to the actual "participation by the party to be bound," giving evidentiary effect to judgments is also fair if the opponent has an opportunity to be heard at the second proceeding. Motumura, supra note 89 , at 1034,1036 . The inequity of his position, however, is that an opponent who had no prior access to the previous proceeding can rarely "offer a satisfactory explanation." FED. R. EvID. 803(22) advisory committee's note.

The government's use of judgments in criminal proceedings is limited to judgments entered against the current defendant. FED. R. EviD. 803(22); see, e.g., United States v. Crispin, 757 F.2d 611,613 (5th Cir. 1985) (judgments against nine aliens for illegally entering the United States inadmissible in prosecution for another defendant's conspiracy to move these very persons within the U.S.). This limitation may be grounded on constitutional protections of criminal defendants:

[T]o the extent that the judgment of conviction reflects another jury's verdict embracing a finding on an element of an offense before the jury to whom the judgment is offered, it trenches upon a defendant's due process right to have the government prove every element of the offense with which he is charged.

Id. at $613 \mathrm{n} .1$

However, felony convictions may be used against nonparties in civil proceedings. FED. R. EviD. 803(22); see, e.g., Schwartz v. United States, 582 F. Supp. 224, 227-28 (D. Md. 1984) (criminal conviction based on ownership of stock in an illegal enterprise admissible to defend against plaintiff's competing claim of ownership).

294. See supra text accompanying notes 133-34.

295. Respect for the force of judgments is the purpose behind Motomura's proposal to expand the admission of judgments as evidence against nonparties. Motomura, supra note 89, at 1055; see also Cleary, supra note 111, at 345 ("According insufficient weight to prior decisions eneourages disrespect and disregard of courts and their decisions and invites litigation.").

The argument of most commentators that convictions must be admitted rests on both accuracy and institutional values. Judgments are admissible because they are highly reliable. Moreover, since we are trusting the present jury to decide the fate of the party, we must also trust the decisions of 


\section{E. The Residual Exceptions}

The exceptions adopted in rules 803(24) and 804(b)(5)-known as the residual, catch-all, or expanding exceptions-establish a novel, noncategorical approach to the admission of hearsay. ${ }^{296}$ They permit the trial judge to admit statements on the basis of the judge's own evaluation of the reliability of the particular statement, the proponent's claim of particular need in the particular case, and notice to the opponent.

During the twelve years in which the residuals have been in effect, proponents have relied on them to offer statements made by multiple declarants, such as surveys and polls; ${ }^{297}$ reports generated by quasi-business duties; ${ }^{298}$ and documents from foreign sources. ${ }^{299}$ The residual exceptions are also used to admit statements of crucial eyewitnesses, such as reports of crimes or torts by victims or police officers; ${ }^{300}$ statements

past juries. See 5 J. WIGMORE, supra note $2, \S 1671$ a, at 808 ("For can we in the same breath say that the jury is to be trusted to determine the fate of the parties in the present case, but that juries generally are not to be trusted and that their verdicts are worthless?'); see also 4 J. WEINSTEIN \& $M$. BERGER, supra note 12, f| 803(22)[1], at 803-359 \& nn.16-18 (collecting authorities). Others argue that use of judgments promotes judicial economy by avoiding multiple expenditures of judicial resources to decide single factual issues. See e.g., D. Louisell \& C. MuELLER, supra note 89, at 888. But see Motomura, supra note 111 , at $1004-05$ (criticizing the judicial economy argument).

296. The language of Federal Rules $803(24)$ and $804(\mathrm{~b})(5)$ is identical in defining statements admissible under these residual exceptions.

Admission of a statement under rule 804 (b)(5) also requires the proponent to prove that the declarant is unavailable pursuant to rule 804(a). Some circuit courts differentiate between the two residual exceptions by attempting to match the circumstantial guarantees of trustworthiness of an item offered under rule 804(b)(5) with the characteristics of the other kinds of statements admitted under rule 804(b). See, e.g., Central Freight Lines, v. NLRB, 653 F.2d 1023, 1026 (5th Cir. 1981); United States v. Bailey, 581 F.2d 341, 346-49 (3d Cir. 1978). Other courts ignore this distinction and apply rule $803(24)$ when the declarant is unavailable. See, e.g., United States v. Friedman, 593 F.2d 109, 118-19 (9th Cir. 1979).

297. See, e.g., Debra P. v. Turlington, 730 F.2d 1405, 1412-13 (11th Cir. 1984) (study to determine whether Florida schools teach skills tested by state's new functional literacy examination); Keith v. Volpe, 618 F. Supp. 1132, 1161-63 (C.D. Cal. 1985) (social survey of persons displaced by Century Freeway), aff'd on other grounds, 784 F.2d 1457 (1986).

298. See, e.g., Moffett v. McCauley, 724 F.2d 581, 584 (7th Cir. 1984) ("it was the regular procedure ... to compile [investigation report by prison officials concerning a strip search incident] whenever a suit is filed . . . . it is reasonable to infer that the [preparers] relied on prison officials with firsthand knowledge of the incident for information. The prison official who prepared the report had a business duty and a public obligation to be accurate."); Litton Sys. v. American Tel. \& Tel. Co., 700 F.2d 785, 818 (2d Cir. 1983) (executive's testimony based on oral reports to him by subordinates "made in the ordinary course of business"), cert. denied, 464 U.S. 1073 (1984).

299. See, e.g., United States v. Loalza-Vasquez, 735 F.2d 153, 157-58 (5th Cir. 1984) (admitting telex received from United States embassy official in Panama stating that a Panamanian official permitted the boarding of a shrimp boat); United States v. Marsh, 747 F.2d 7 (1st Cir. 1984) (admitting documents evincing Denmark's consent to a prosecution by United States government); Karme v. Commissioner, 673 F.2d 1062, 1064-65 (9th Cir. 1982) (admitting microfilm records of Netherland Antilles bank where proponent produced the foundation witness who had made the documents); United States v. Friedman, 593 F.2d 109, 118-19 (9th Cir. 1979) (admitting documents from Chilean official that summarized public records reciting entry and exit dates of defendants from Chile).

300. See, e.g., United States v. Rouco, 765 F.2d 983, 994 (11 th Cir. 1985) (admitting statement 
made by defendants and their associates; ${ }^{301}$ and grand jury testimony of the unavailable cohorts of criminal defendants implicating the defendants in criminal activities. ${ }^{302}$

Courts have taken two main approaches to the requirement that statements admitted under the residuals have "equivalent circumstantial guarantees of trustworthiness" to the categorical exceptions. Some courts have analyzed the circumstances existing when the particular declarant perceived, remembered, and made a statement about the relevant event. They have found the trustworthiness requirement to be satisfied if these circumstances generate inferences that the declarant's perception and statement occurred during routine performance of jobrelated activities, ${ }^{303}$ or that the declarant had no motive to fabricate when she made the statement. ${ }^{304}$

by drug enforcement agent to his supervisor 30 minutes after the incident that he "received the cocaine from Orlando Hernandez at an automobile body shop."), cert. denied, $106 \mathrm{~S}$. Ct. 1646 (1986); United States v. Iaconetti, 406 F. Supp. 554, 559 (E.D.N.Y.) (admitting accusation of defendant made to superiors by recipient of bribe request "close on the heels of the criminal event"), aff'd, 540 F.2d 574 (2d Cir. 1976), cert. denied, 429 U.S. 1041 (1977).

301. See, e.g., United States v. Leslie, 542 F.2d 285, 290-91 (Sth Cir. 1976) (incriminating statements made to FBI by defendant's accomplices). Statements of exculpation are usually excluded. See United States v. DeLuca, 692 F.2d 1277, 1285 (9th Cir. 1982) (excluding telephone conversation taped by informant containing exculpatory statements by defendant). But see Turbyfill v. International Harvester Co., 486 F. Supp. 232, 234-35 (E.D. Mich. 1980) (admitting writtell statement of defendant's deceased employee made shortly after plaintiff's accident at defendant's used car lot.)

302. For cases in which courts have admitted grand jury testimony of co-conspirators, see United States v. Barlow, 693 F.2d 954, 960-63 (6th Cir. 1982), cert. denied, 461 U.S. 945 (1983); United States v. Garner, 574 F.2d 1141, 1144 (4th Cir.), ccrt. denied, 439 U.S. 936 (1978); United States v. West, 574 F.2d 1131, 1134-36 (4th Cir. 1978); United States v. Carlson, 547 F.2d 1346, 1353-55 (8th Cir. 1976), cert. denied, 431 U.S. 914 (1977). But cf. United States v. Gonzalez, 559 F.2d 1271, 1273 (5th Cir. 1977) (excluding grand jury testimony of previously convicted coconspirator who had been given immunity and pressured to testify).

Judges opposed to using the residual exceptions to admit grand jury testimony of criminal cohorts find such hearsay to be neither exceptional nor inherently trustworthy. Although it is given under oath, they note that such testimony is not cross-examined, that the opponent is not present, and that the grant of immunity creates the risk of conscious or unconscious embellishment. The cases allowing admission consider such factors as the existence of prior consistent statements by the declarant, the declarant's assertion of sincerity, and extrinsic proof corroborating the contents of the hearsay statements. See, e.g., West, 574 F.2d at 1135; Carlson, 547 F.2d at 1354.

303. See, e.g., United States v. Cowley, 720 F.2d 1037, 1044-45 (9th Cir. 1983) (admitting Santa Barbara postmark as a trustworthy indication that envelope had passed through Santa Barbara), cert. denied, 465 U.S. 1029 (1984); Friedman, 593 F.2d at 119 ("The Chilean official who summarized the official immigration records surely encountered no problems of perception or memory in transferring the information from the records to the travel documents. There was no difficulty in the narration of the information ... it pertains only to dates of entry and exit and involves no statements of a testimonial nature as to what Johnson or Garrity did in Chile"); see also cases cited supra notes 298-99.

304. The circumstances found to affect the declarants' motive differ widely. See, e.g., Herdman v. Smith, 707 F.2d 839, 842 (5th Cir. 1983) (declarant risked criminal sanction if lying under oath); United States v. Boulahanis, 677 F.2d 586, 588 (7th Cir.) (declarant was "a disinterested witness-a mere bystander, with no axe to grind"), cert. denied, 459 U.S. 1016 (1982); Robinson v. Shapiro, 646 
In the second approach, courts examine whether other evidence in the case corroborates the content of the hearsay statement. If the declarant's version of the relevant event is corroborated, some courts infer trustworthiness sufficient to admit it. ${ }^{305}$ Admitting hearsay under the corroboration test does not satisfy foundation fact policy. It does not address the trier's need for foundation facts to use general knowledge and experience to evaluate specific statements made by specific declarants. This function is particularly important when the eyewitness statements are about crucial disputed facts. Whether hearsay is coherent with other evidence in the case is an important factor in the trier's ultimate decision of disputed issues, and may cause the trier to reevaluate the declarant's reliability. However, the effects of corroboration on the trier's evaluation can be decided only after all the evidence is in, with hindsight. A corroboration test would admit hearsay without adequate foundation facts, and would create serious probleins of adinmistration. ${ }^{306}$

F.2d 734, 743 (2d Cir. 1981) (declarant had "little motive to dissemble, since following Rendo's directions made the job considerably more difficult"); United States v. White, 611 F.2d 531, 537-38 (Sth Cir.) (foundation witness testified that declarant signed form after reading warning of criminal prosecution for submission of false claims), cert. denied, 446 U.S. 992 (1980); Furtado v. Bishop, 604 F.2d 80, 91 (1st Cir. 1979) (declarant was an "eminent attorney," who appreciated significance of oath, and was "basically a disinterested party"), cert. denied, 444 U.S. 1035 (1980); Huff v. White Motor Corp., 609 F.2d 286, 292 (7th Cir. 1979) (declarant "was not being interrogated. . . There was no reason for him to invent the story of the preexisting fire in the cab. The story was contrary to his pecuniary interest").

Courts have also excluded statements under the residual exceptions when they have found that circumstances generate a motive for insimcerity. For instance, courts have occasionally excluded statements of defendants made after indictment or investigation. E.g., United States v. Woosley, 761 F.2d 445, 449 (8th Cir. 1985); United States v. DeLuca, 692 F.2d 1277, 1285 (9th Cir. 1982); see also NLRB v. United Sanitation Serv., 737 F.2d 936, 940 (11th Cir. 1984) (excluding self-serving affidavit of deceased who had alleged employment discrimination); United States v. Pinto-Mejia, 720 F.2d 248, 258 (2d Cir. 1983) (Venezuelan Certificate excluded as containing "aura of eagerness" to deny Venezuelan nationality to vessel in question), modified, 728 F.2d 142 (1984); United States v. Fredericks, 599 F.2d 262, 265 (8th Cir. 1979) (excluding statement by girlfriend of defendant's brother whose possible motive was to exculpate defendant); Land v. American Mut. Ins. Co., 582 F. Supp. 1484, 1487 (E.D. Mich. 1984) (excluding statement of victim of industrial accident concerning her own lack of fault); Dogan v. Hardy, 587 F. Supp. 967, 969 (D. Miss. 1984) (excluding selfserving statement by driver of car involved in accident).

305. See, e.g., United States v. Walker, 696 F.2d 277, 281 (4th Cir. 1982) (admitted portion of declarant's grand jury testimony was consistent with only one other witness, but inferred reliability from the rest of that testimony being verified and undeniable), cert. denied, 464 U.S. 891 (1983); United States v. Murphy, 696 F.2d 282, 286 (4th Cir. 1982) (declarant's grand jury testimony corroborated by other testimony and proof of key facts), cert. denied, 461 U.S 945 (1983); United States v. West, 574 F.2d 1131, 1135 (4th Cir. 1978) (declarant's grand jury testimony about drug purchases corroborated by agents following, photographing, and recording declarant's movements); United States v. Garner, 574 F.2d 1141, 1146 (4th Cir.) (declarant's grand jury testimony about defendant's movements abroad was corroborated, but testimony about defendant's drug-dealing activities was not), cert. denied, 439 U.S. 936 (1978).

306. See, e.g., Boulahanis, 677 F.2d at 589 (when declarant's statement was introduced, government did not know another crucial witness would corroborate). The discussion in Note, supra note 18, at 1800-01, of a "necessity" test applies equally to a corroboration test: "Problems [are] raised by the order of presentation, the difficulty of changing previous rulings, ... and the sheer 
Courts should therefore interpret the residual exceptions to require that trustworthiness be determined by the circumstantial approach. The proponent should produce witnesses who are subject to cross-examination concerning the circumstances at the time of the declarant's perceiving, remembering, and making a statement about the relevant event. An identification witness could be substituted only if a process witness is not available, and if basic process facts are contained in the statement itself. $^{307}$

complexity of making rulings that depend upon the variety of possible configurations of other evidence in a given case." Lempert and Saltzburg observe that a test based on consistency, the type of corroboration present in United States v. Garner, 574 F.2d 1141 (4th Cir. 1978), blurs the separate elements of a case. R. LEMPERT \& S. SALTZBURG, supra note 46, at 503.

307. Under the foundation fact approach, polls or surveys could be admitted on the basis of the expertise of the reporting declarants who conducted them, so long as a knowledgeable foundation witness testified concerning the methodology and expertise employed. See supra Example 10, text accompanying notes $138-43$.

If documents generated in foreign countries were offered under the foundation fact approach, it is likely that knowledgeable process foundation witnesses would not be available. Therefore, the adjusted foundation would apply. The statement itself could contain process facts. A qualified identification witness could testify about the declarant's identity or job description. Process foundation facts about the foreign document might be obtained from other admissible hearsay sources and testimony by a foundation witness, such as the FBI agent who microfilmed documents in Karme v. Commissioner, 673 F.2d 1062 (9th Cir. 1982), or the witness who authenticated the Chilean travel document in United States v. Friedman, 593 F.2d 109 (9th Cir. 1979). A similar approach, embodied in part of the Comprehensive Crime Control Act of 1984, 18 U.S.C. $\S 3505$ (1984), admits foundation facts for foreign business records through sworn certification by the foreign custodian.

The foundation fact approach would also admit statements of both victims and defendants. In United States v. Iaconetti, 406 F. Supp. 554, 559 (E.D.N.Y.), aff'd, 540 F.2d 574 (2d Cir. 1976), cert. denied, 429 U.S. 1041 (1977), the declarant himself testified at trial and remembered both the event and his statement. In both United States v. Rouco, 765 F.2d 983, 994 (1 lth Cir. 1985), cert. denied, 106 S. Ct. 1646 (1986), and United States v. McCall, 740 F.2d 1331, 1335 (4th Cir. 1984), the foundation witness who described the making of the statement was the declarant's coworker and could probably have qualified as an identification witness. The declarant's statements themselves contained facts about perception opportunities. Thus, these situations would have satisfied the adjusted foundation.

In Turbyfill v. International Harvester Co., 486 F. Supp. 232, 234-35 (E.D. Mich. 1980), the statements contained facts about perceiving, remembering, and making the statement regarding thc relevant event. The foundation witness for the hearsay statement was the declarant's supervisor who could have qualified as an identification witness. In United States v. Leslie, 542 F.2d 285, $290-91$ (5th Cir. 1976), the declarants themselves testified at trial, exonerating the defendant. Their inconsistent hearsay statements, inadmissible under rule $801(\mathrm{~d})(\mathrm{l})(\mathrm{A})$, were admitted under the residual exception. Id. These statements would have also satisfied the foundation fact approach.

For defendants to admit their own exculpatory statements, however, they would have to produce the basic process foundation, which includes a witness knowledgeable about the defendants' perception of the exculpating facts. If such a witness existed, the defendants' use of their own hearsay statements probably would not be necessary.

Under the foundation fact approach, the debate over the admission of grand jury statements would not focus on trustworthiness. Instead, if all process foundation witnesses (including the declarant) were unavailable to the prosecution, then the prosecution would have to satisfy the adjusted foundation with a qualified identification witness. This requirement would provide the trier of fact with information about the motivational factors bearing on the declarant's sincerity. 
Of course, under a full-blown foundation fact approach, hearsay statements should be admitted without regard for the trial judge's preliminary evaluation of the declarant's trustworthiness. This may lead to the admission of hearsay that today appears risky and would be rejected. However, allowing the judge to reject statements that satisfy the basic or adjusted standard of admission because she doubts a declarant's reliability undermines the trier's independence and decreases the proponent's freedom of choice. The trier is able to evaluate weaknesses in declarants' statements and is the proper institutional actor to do so. ${ }^{308}$

\section{CONCLUSION}

In this Article, I have argued that judicial control over the use of hearsay is necessary because the trier of fact requires foundation facts to evaluate the reliability of hearsay, and because the opponent requires a knowledgeable source of foundation facts to cross-examine at trial. Were hearsay admitted freely, proponents could minimize foundation fact and foundation witness production to suit their tactical needs. This would undermine the accuracy of adjudicative factfinding and shift the balance of advantage in favor of proponents.

In my view, the categorical approach of the current hearsay rule creates these same risks. Further, it undermines the trier's independence by denying the trier use of its own general knowledge and experience in determining what is true, or at least who should be relied on in determining what is the historical truth in the particular case. Thus, I have proposed that the hearsay rule should reflect not concern about the reliability of hearsay, but rather concern about its evaluation.

The foundation fact approach that I propose would address the trier's and the opponent's need for foundation facts and foundation wit-

308. Some courts have identified the jury, acting as trier of fact, as the "appropriate arbiter of the truth, the body best suited for sifting falsehoods from facts" in cases involving the evaluation of out-of-court testimony. United States v. Hemmer, 729 F.2d 10, 17 (1st Cir.) (refusing to exclude grand jury testimony characterized as perjurious), cert. denied, 467 U.S. 1218 (1984).

The kinds of facts that judges believe render statements untrustworthy under the residual exceptions are those that the trier seems competent to evaluate as well. See, e.g., McCall, 740 F.2d at 1334 (written and oral accounts of declarant's description of robber contained contradictions); United States v. Colson, 662 F.2d 1389, 1392 (11th Cir. 1981) (statement exculpating defendant was given by twice-convicted felon and contained nonfactual opinions, conclusions, and self-laudatory comments); United States v. Atkins, 618 F.2d 366, 373 (5th Cir. 1980) (exculpatory letters were from an alleged co-conspirator who "could well have been motivated by his friendship to fabricate statements"); United States v. Hinkson, 632 F.2d 382, 386 (4th Cir. 1980) (excluded declarant's confession to defendant's alleged crime because declarant's claim of murder "would seem to be braggadocio"); Fredericks, 599 F.2d at 265 (statements by girlfriend of defendant's brother excluded due to her exculpatory motive); Land v. American Mut. Ins. Co., 582 F. Supp. 1484, 1487 (E.D. Mich. 1984) (declarant's account of accident was "so clearly in her own interest that [its] trustworthiness must be subject to serious doubt"); $c f$. Herdman v. Smith, 707 F.2d 839, 842 (5th Cir. 1983) (defendant's basis for claiming that declarant was untrustworthy "strain[ed] credulity"). 
nesses. Changes in practice would occur whether this approach replaced the current hearsay rule wholesale, or were adopted only in part through revision of the categorical exceptions. The most pervasive change would be proponents' more frequent production of foundation witnesses knowledgeable about the declarant's perception opportunity. This is a good hearsay policy. It corrects the current hearsay rule's overemphasis on categorical sincerity and its neglect of the trier's ability to evaluate perception. The adjusted approach would insure that the proponent would at least produce an identification witness. This is also good policy that corrects the current rule's trend toward admitting hearsay on a wholly documentary foundation.

Wholesale adoption of the foundation fact approach would also result in the exclusion of some currently admitted hearsay. Whether this would be reliable or unreliable hearsay simply cannot be known. It is admitted today, under the guise of legislative and judicial belief in its trustworthiness, but without attention paid to the ability of the trier to assess its value. Under the foundation fact approach, exclusion would be the last resort when the proponent failed to produce either a knowledgeable process foundation witness or an identification witness. When the hearsay declarant is an important source of proof for the trier to evaluate, this result is justified.

The foundation fact approach would also admit some statements that currently do not qualify under the categorical exceptions. The proponent would have more freedom in choosing proof, and the trier would have more independence to apply its general knowledge and experience to evaluate these hearsay statements. Although some of the statements chosen might appear risky to lawyers and judges trained under the categorical approach, it is the trier of fact who is charged with evaluating hearsay. It is less important how hearsay appears to the bench and bar than whether the trier is given an adequate foundation to evaluate it. Moreover, the opponent will have trial access to people knowledgeable about the foundation for those statements.

These changes in practice conform to the theory underlying the foundation fact approach. When the opponent has fair access and the trier is given an adequate foundation for evaluation, hearsay should be admitted. This theory serves the values of operational accuracy, independence of the trier, and fairness between the adversaries. Explicit recognition of these values provides a more rational and legitimate basis for admitting hearsay than does the patchwork of expedience and unsupported assumptions about reliability that constitutes the current categorical approach. 



\section{California Law Review}

\begin{tabular}{lll}
\hline \hline VOL. 75 & JULY 1987 & No. 4
\end{tabular}

Copyright (C) 1987 by California Law Review, Inc.

\section{BOARD OF EDITORS}

1986-87

Editor-in-Chief

KENTON J. KING

Managing Editor

Paul. HuRdiow

Senior Articles

Editor

EVAN R. Cox

Senior Executive Editor

ANN Hopkins

Articles Editors

SUSAN JAMISON

ERIKA A. KELTON

Executive Editors

BRAD C. LEWIS

GERDA M. ROY

DORA MAO

TERDEMA L. USSERY II

Book Review Editor

SHELLEY R. BARBER

VALERIE SMITH BOYD

DENNIS CLINE

GILBERT COLOMA-AGARAN

DREW E. EDWARDS

MARK D. FlaNAGAN

Cameron artigue

CAREY LiNKON BRANDSTETTER

DAVID LOREN BURG

TOM BUSH

LEE HEROLD

Associate Editors

Charles Gray

LINDA HELYAR

LESLIE E. JOHN

MaRA Diane MoRner

DAVID MOYCE

Senior Note \& Comment Editor

NANCY J. TAYLOR

Note \& Comment Editors

LEAH HAMMETT

VIRGINIA MELLEMA

NEIL A. F. POPOVIC

Research \& Topics Editor MARTY SlaughteR

Members

LAURa T. Howard

BRUCE LEICHTY

David B. LEVANT

SANDRA LEVIN

ROBYN-MARIE LYON

A.A. Ricciardull.

DAVID A. RUSH

Holly SPRAgue

Michael STEIN

MEgAN L. WAGNER

Martha Matthews

ANDREW S. MORRISON

DANA SHILling RIEgER

William ReEd SaWyers

TIMOTHY C. STUTLER 


\section{California Law Review}

\begin{tabular}{lll}
\hline \hline Vol. 75 & JULY 1987 & No. 4 \\
\hline
\end{tabular}

Copyright ( 1987 by California Law Review, Inc.

\section{BOARD OF EDITORS}

1987-88

\section{Editor-in-Chief}

JOHN O'HARA HORSLEY

Managing Editor

ROGER MYERS

Senior Articles

Editor

MARINA C. HSIEH

Articles Editors

Michael G. Colantuono

Carroll Dorgan

Christina Spaulding

Book Review Editor

Mark Peter KIndall

MARK A. Albert

MARC BECKER

MICHAEL BRODY

Jonathan L. Diesenhaus

ALAN DURHAM

LINDA HELYAR

BARCLAY JAMES KAMB

RICHARD J. BRENER

LUISA DANIELS

MARK ABBotT

PaUl Ades

ADAM C. BELSKY

JEFF BLEICH

MICHAEL BORO

LANCE W. BRIDGES

Gerald Carroll

JiM CAVAlLaRo

Charles Q. Clay, III

MARCY COX

TIM DEWITT

LAURA FASHING

ROSEMARY A. FILOU

SCOTT GARDNER
Senior Executive Editor

LYNDON F. BITTLE

Executive Editors

KEVIN A. COYLE

Meredith A. Nelson

DAvid A. ZAPOLSKY

\section{Associate Editors}

AARON KEYT
DARYL S. LANDY
JOEL MACKEY
SAM MILLER
KELLY L. MIN
ROBERT A. PULVER
JOSEPH ROHN

\section{Members}

MARK C. HoLSCHER

JANET LUCK

KEVIN P. QUINN

JONATHAN GRAUBART

GARY S. HARRISON

Steve Hellman

Martina A. Hone

SUNHEE JUHON

ELLEN E. KAULBACH

Alison KeEL

KAREN KENNARD

RALPH KOKKA

CyNTHia LeE

RANDALL R. LEE

JEFF LEWIS

MARK MERVA

BRAd MIDdLETON

PhILIP MONRAD
Senior Note \& Comment Editor

DANIEL W. BuRKHARDT

Note \& Comment Editors

MARC HARRIS

Michael J. MORRIS

KENNETH L. WAINSTEIN

Research \& Topics Editor GARY LOUIE

Daniel L. Schwartz

SANDRA SCOTT

ROGER SIGAL

WENDY STRIMLING

DiANE TURNER

Claire A. WALLS

Dirk Magnus Wilson

D. JAY RITT

SETH MORRIS SKOOTSKY

JANICE NADLER

HELEN NORTON

SUE OKUDA

ANTHONY ORZA

TAMARA POWELL

Marco Quazzo

JILL ROBINSON

STUART N. SENATOR

KENNETH JOHN SHAFFER JOSEPH KENT SIINO

PaUl STARTZ

Michael F. Tubach

JON TIGAR

HOWARD YELLEN 
